\title{
HOLE-TYPE AEROSPIKE COMPOUND NOZZLE THRUST VECTORING
}

\author{
A Thesis \\ presented to \\ the Faculty of California Polytechnic State University, \\ San Luis Obispo
}

\author{
In Partial Fulfillment \\ of the Requirement for the Degree \\ Master of Science in Mechanical Engineering
}

by

September 2009 
(C)2009

Stanley lkuo Beebe

ALL RIGHTS RESERVED 
TITLE:

AUTHOR:

DATE SUBMITTED:

COMMITTEE CHAIR:

COMMITTEE MEMBER:

COMMITTEE MEMBER:
HOLE-TYPE AEROSPIKE COMPOUND NOZZLE THRUST VECTORING

STANLEY IKUO BEEBE

SEPTEMBER 2009

WILLIAM R. MURRAY, Ph. D.

THOMAS W. CARPENTER, Ph. D.

KIM A. SHOLLENBERGER, Ph. D. 


\author{
ABSTRACT \\ Hole-Type Aerospike Compound Nozzle Thrust Vectoring \\ Stanley Ikuo Beebe
}

Compound aerospike nozzles were designed and tested as part of an ongoing experimental study to determine the feasibility of thrust vectoring an aerospike nozzle with the addition of a secondary port. Earlier phases of the study have indicated that a compound aerospike nozzle could provide sufficient thrust vectoring. The addition of a hole-type secondary port was found to provide effective thrust vectoring.

Experiments were carried out to determine the effects of secondary port size, secondary port inlet geometry and compound aerospike nozzle chamber pressure. Results show good predictability, axisymmetric flow, and emphasize the importance of a radius on secondary port inlet geometry.

Keywords: aerospike, thrust vectoring, compound nozzle. 


\section{ACKNOWLEDGMENTS}

I would like to thank my mother and sister for their support during the many years of my enrollment at Cal Poly, and thanks Dad, wish you could have read this.

A special word of thank you to my thesis committee members William Murray, Thomas Carpenter and Kim Shollenberger. I appreciate the opportunity to be part of this project. I have learned much more than rocket science during the course of my study, thanks for your help and encouragement as friends and mentors.

Thanks to Ty and Trudie Safreno at Trust Automation for generous use of the facilities and resources.

This work was funded in part by grants from the NASA Dryden Flight Research Center STTR Grants: Phase II, Contract NND06AB82C, 06/06 - 08/08; Phase I, Contract NND05AA53C, 01/05 - 01/06. 


\section{Table of Contents}

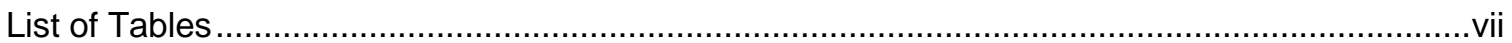

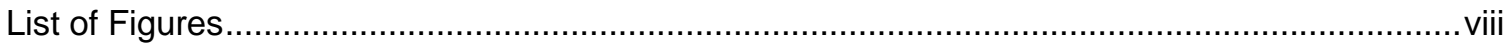

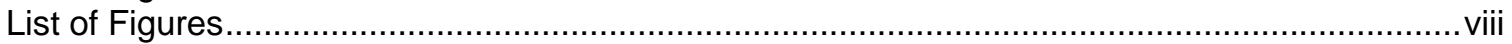

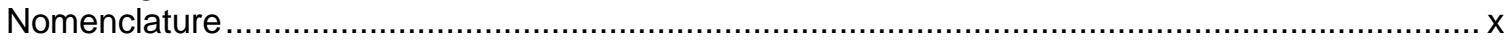

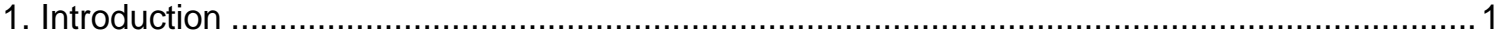

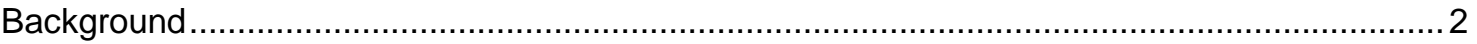

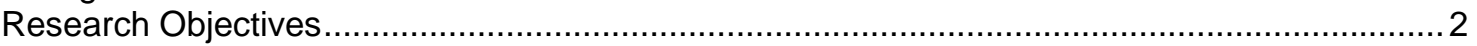

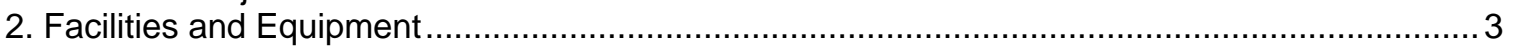

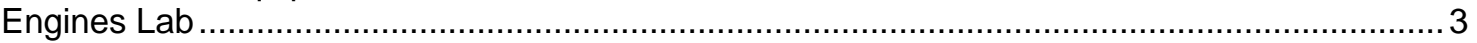

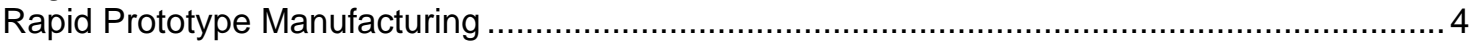

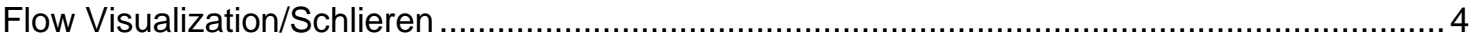

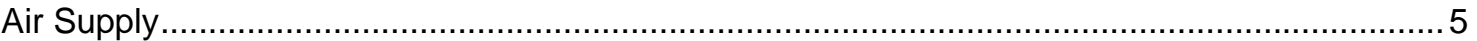

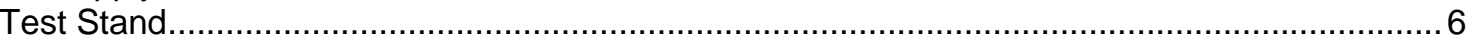

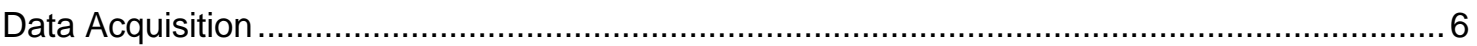

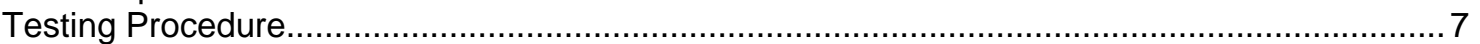

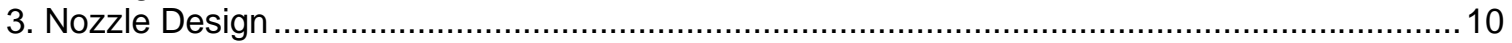

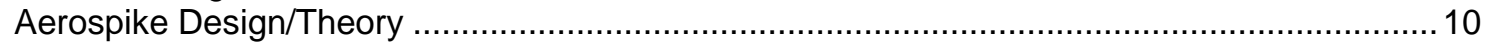

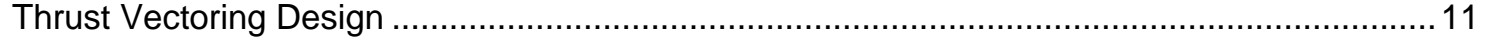

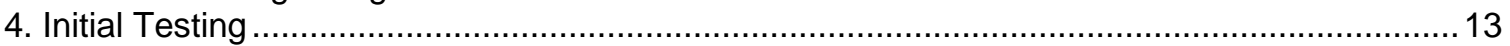

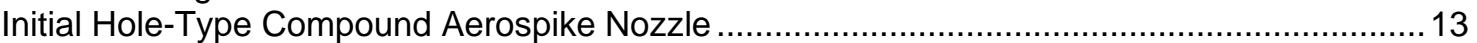

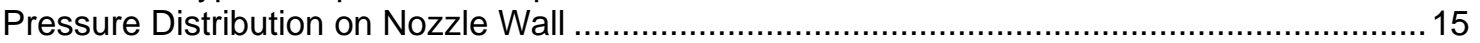

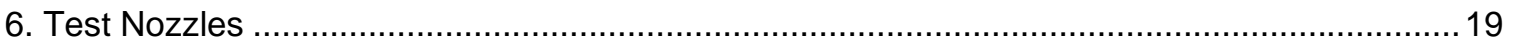

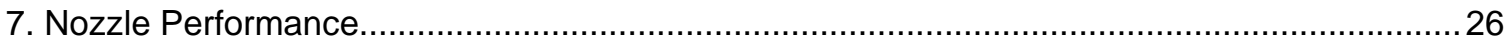

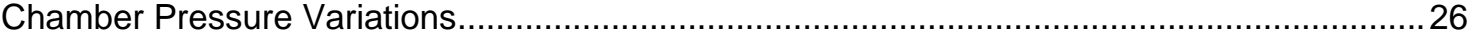

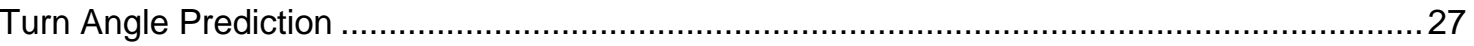

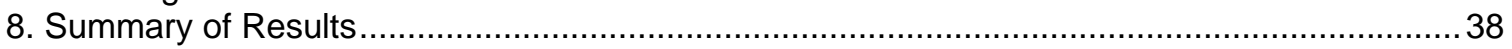

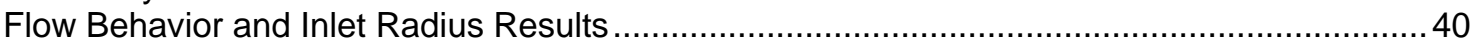

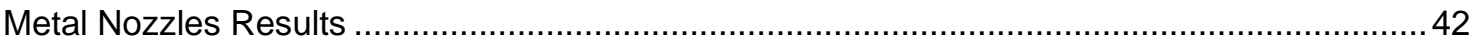

Chamber Pressure and Turn Angle Results ............................................................. 44

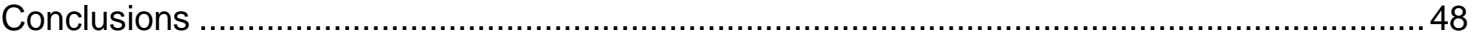

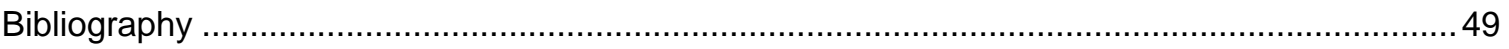

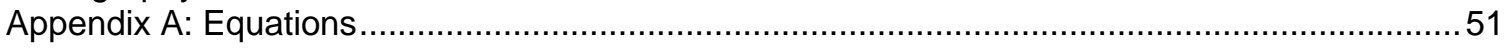

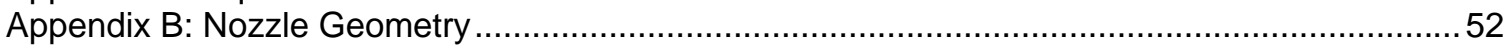

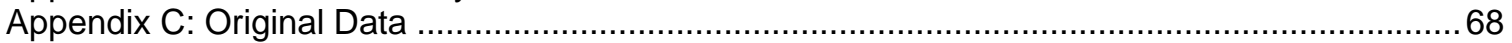




\section{List of Tables}

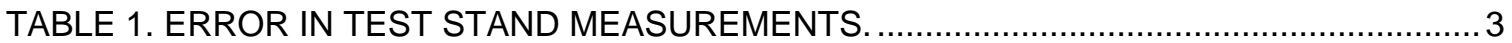

TABLE 2. PRESSURE DISTRIBUTION ALONG NOZZLE WALL........................................ 17

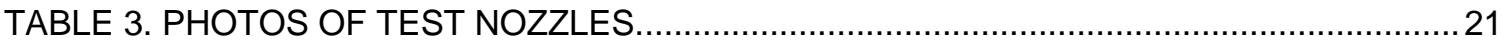

TABLE 4. PHOTOS OF METAL TEST AEROSPIKE NOZZLES .............................................. 22

TABLE 5. CALCULATED AND MEASURED COMPOUND NOZZLE FORCES AND TURN

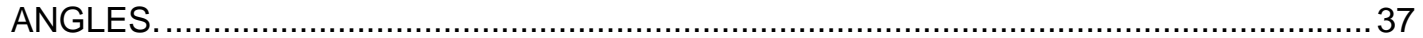

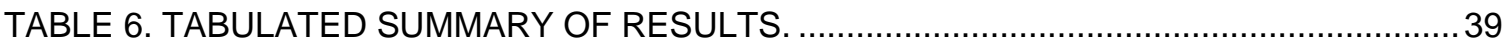




\section{List of Figures}

FIGURE 1. LAYOUT OF SUPPLY AIR SYSTEM SHOWING INDIVIDUAL COMPONENTS. .........8 FIGURE 2. TEST STAND SHOWING BELLOWS, PLENUM, AND A TEST NOZZLE.....................9

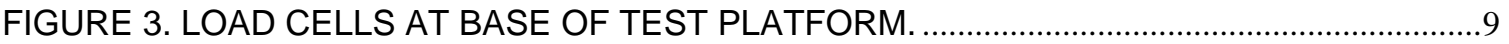

FIGURE 4. DIAGRAM OF TERMS DESCRIBING COMPOUND AEROSPIKE NOZZLE GEOMETRY.

FIGURE 5. INITIAL HOLE-TYPE COMPOUND AEROSPIKE NOZZLE CONFIGURATION.........14

FIGURE 6. "NPR20 HOLE" SCHLIEREN PHOTOGRAPH AND CROSS-SECTION DRAWING..14

FIGURE 7. PRESSURE TAP EQUIPPED NPR20 NOZZLE.

FIGURE 8. NOZZLE WALL STATIC PRESSURE VERSUS AXIAL POSITION PRESSURE TAP RESULTS.

FIGURE 9. SCHLIEREN PHOTOGRAPHS OF NON-COMPOUND AEROSPIKE NOZZLES. .....22

FIGURE 10. SCHLIEREN PHOTOGRAPHS OF NPR6 COMPOUND NOZZLES...........................23

FIGURE 11. SCHLIEREN PHOTOGRAPHS OF NPR20 COMPOUND NOZZLES, NO INLET RADIUS

FIGURE 12. SCHLIEREN PHOTOGRAPHS OF NPR50 COMPOUND AEROSPIKE NOZZLES.

FIGURE 13. SCHLIEREN PHOTOGRAPHS OF NPR20 METAL AEROSPIKE NOZZLES...........24

FIGURE 14. SCHLIEREN PHOTOGRAPHS OF NPR2O COMPOUND AEROSPIKE NOZZLES

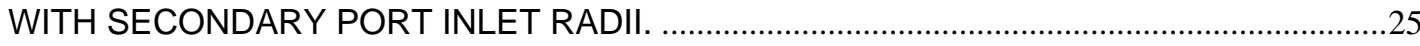

FIGURE 15. ABSOLUTE TURN ANGLE VERSUS NPR, RESULTS OF VARYING CHAMBER PRESSURE.

FIGURE 16. DIAGRAM OF COMPOUND AEROSPIKE NOZZLE FORCES.

FIGURE 17. NPR6 HOLE 3 SECONDARY PORT MEASURED AND CALCULATED RADIAL VECTORING FORCE VERSUS NPR

FIGURE 18. NPR20 HOLE 3 SECONDARY PORT MEASURED AND CALCULATED RADIAL VECTORING FORCE VERSUS NPR.

FIGURE 19. NPR20 HOLE 5 SECONDARY PORT MEASURED AND CALCULATED RADIAL

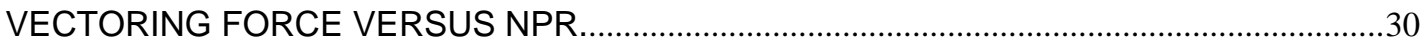

FIGURE 20. NPR50 HOLE 3 SECONDARY PORT MEASURED AND CALCULATED RADIAL VECTORING FORCE VERSUS NPR.

FIGURE 21. NPR6 HOLE 3 AEROSPIKE NOZZLE MEASURED AND CALCULATED AXIAL FORCE VERSUS NPR

FIGURE 22. NPR20 HOLE 3 AEROSPIKE NOZZLE MEASURED AND CALCULATED AXIAL FORCE VERSUS NPR.

FIGURE 23. NPR20 HOLE 5 AEROSPIKE NOZZLE MEASURED AND CALCULATED AXIAL FORCE VERSUS NPR.

FIGURE 24. NPR50 HOLE 3 AEROSPIKE NOZZLE MEASURED AND CALCULATED AXIAL FORCE VERSUS NPR.

FIGURE 25. NPR6 HOLE 3 ABSOLUTE TURN ANGLE VERSUS NPR COMPARISON OF CALCULATED AND MEASURED RESULTS.

FIGURE 26. NPR20 HOLE 3 ABSOLUTE TURN ANGLE VERSUS NPR COMPARISON OF CALCULATED AND MEASURED RESULTS.

FIGURE 27. NPR20 HOLE 5 ABSOLUTE TURN ANGLE VERSUS NPR COMPARISON OF CALCULATED AND MEASURED RESULTS.

FIGURE 28. NPR50 HOLE 3 ABSOLUTE TURN ANGLE VERSUS NPR COMPARISON OF CALCULATED AND MEASURED RESULTS.

FIGURE 29. NPR20 HOLE 2 PRESSURE DISTRIBUTION AT INLET OF SECONDARY PORT.

FIGURE 30. SCHLIEREN PHOTOGRAPHS OF TWO NPR20 METAL NOZZLES.

FIGURE 31. COMPARISON BETWEEN CALCULATED AND MEASURED TURN ANGLES FOR NPR6 NOZZLES ON A RUN-BY-RUN LEVEL.

FIGURE 32. COMPARISON BETWEEN CALCULATED AND MEASURED TURN ANGLES FOR NPR20 NOZZLES ON A RUN-BY-RUN LEVEL. 
FIGURE 33. COMPARISON BETWEEN CALCULATED AND MEASURED TURN ANGLES

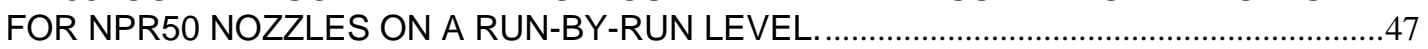

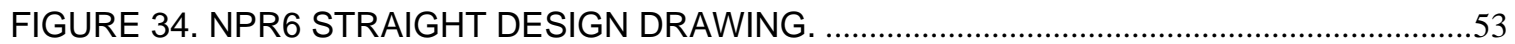

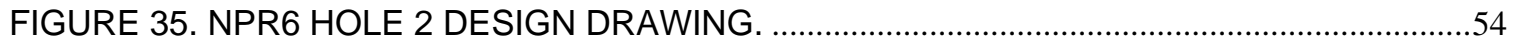

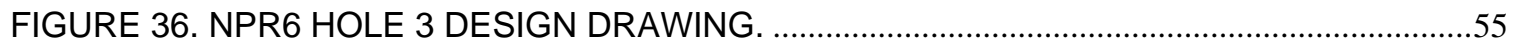

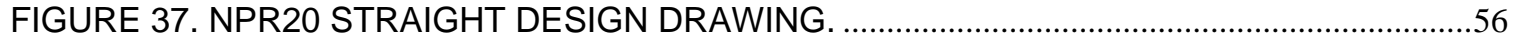

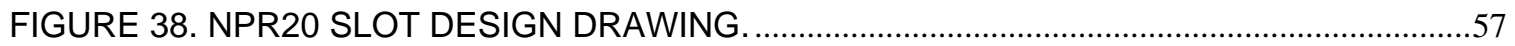

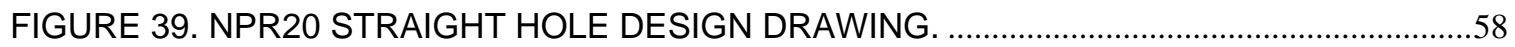

FIGURE 40. NPR20 STRAIGHT PRESSURE TAP DESIGN DRAWING ..........................................59

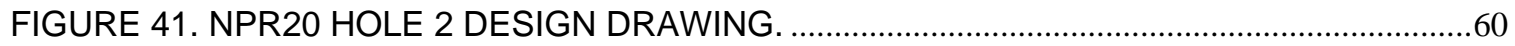

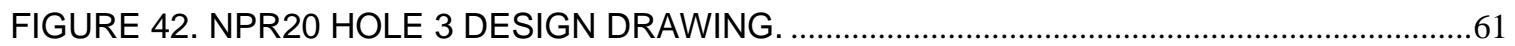

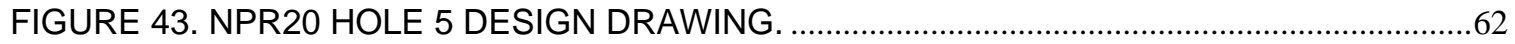

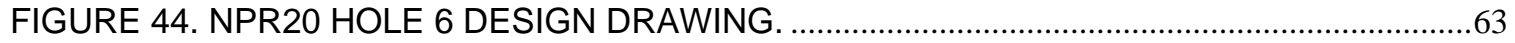

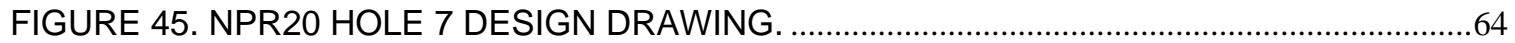

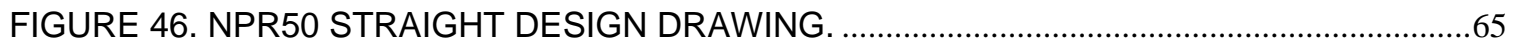

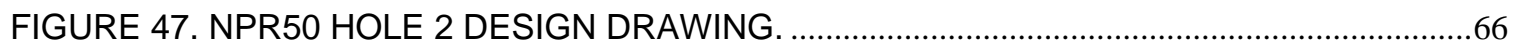

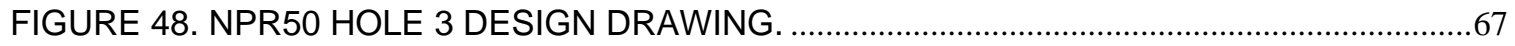




\section{Nomenclature}

Right NPR Nozzle Pressure Ratio measured on the right-hand plenum; the ratio between chamber pressure and ambient pressure.

$F_{X} \quad$ Force measured in the radial " $X$ " direction (lbf).

$F_{y} \quad$ Force measured in the radial " $Y$ " direction (lbf).

$F_{z} \quad$ Force measured in the axial " $Z$ " direction (lbf).

Mx Moment measured about the "X" axis (in-lbf).

My Moment measured about the " $Y$ " axis (in-lbf).

Mz Moment measured about the " $Z$ " axis (in-lbf).

$\mathrm{W}_{\mathrm{p}} \quad$ Measured mass flow rate of supply air $(\mathrm{lbm} / \mathrm{s})$.

$\mathrm{W}_{\mathrm{i}} \quad$ Ideal (calculated) mass flow rate of supply air (lbm/s).

$\mathrm{F}_{\mathrm{i}} \quad$ Ideal (calculated) nozzle force in the axial " $\mathrm{Z}$ " direction (lbf).

$\mathrm{F}_{\mathrm{r}} \quad$ Measured resultant force of the nozzle (lbf).

$\delta_{\text {pitch }} \quad$ Angle of pitching force generated by the thrust vectoring $\left(^{\circ}\right)$.

$\delta_{\text {yaw }}$ Angle of yawing force generated by the thrust vectoring $\left({ }^{\circ}\right)$.

$\delta_{\mathrm{r}}$ Overall resultant turn angle produced by the thrust vectoring $\left(^{\circ}\right)$. Calculated resultant turn angle $\left(^{\circ}\right)$.

$A_{t}$ Throat area $\left(\mathrm{in}^{2}\right)$.

$A_{e} \quad$ Exit area $\left(i n^{2}\right)$

$\mathrm{P}_{1} \quad$ Chamber pressure (psi)

$\mathrm{T}_{1} \quad$ Chamber temperature $\left({ }^{\circ} \mathrm{F}\right)$

F calc Calculated force produced by the hole-type compound nozzle (lbf).

$\mathrm{F}_{\text {vector }} \quad$ Measured force produced by the hole-type compound nozzle (lbf). 


\section{Introduction}

Inherent to the aerospike nozzle is high efficiency due to altitude compensation and throttling capability unique to the aerospike nozzle geometry. Very little research has been conducted regarding the thrust vectoring capability of the annular aerospike nozzle. The combination of high efficiency, throttling capability, and thrust vectoring is the ideal stepping stone to the future of commercial space access.

California Polytechnic State University, San Luis Obispo, has created a substantial research program to develop a thrust vectoring system for annular aerospike rocket nozzles. Preliminary testing has identified three potential methods for aerospike nozzle thrust vectoring: gimbaling of a finned aerospike, the addition of a slot-type secondary port, and the addition of a hole-type secondary port ${ }^{1}$. The focus of this thesis is the experimental investigation of the compound aerospike nozzle formed by the addition of a secondary port.

The hole-type secondary port redirects a portion of the combustion chamber gases before they have passed through the aerospike nozzle throat. The location of the hole-type secondary port and its geometry are evaluated in this thesis. Effects of hole size and chamber pressure are examined as well as effects of the secondary port on the aerospike nozzle flow. The importance of the secondary port inlet geometry is also observed.

\footnotetext{
1 “Optimal Thrust Vectoring for an Annular Aerospike Nozzle,” NASA STTR Grants: Phase II, Contract NND06AB82C, 06/06 - 08/08; Phase I, Contract NND05AA53C, 01/05 - 01/06.
} 


\section{Background}

Aerospike development and testing conducted at General Electric Company and Rocketdyne since the early 1960s have demonstrated the potential of the aerospike nozzle. These early tests produced thrust levels up to 250,000 lbf. Later tests done in the 1970s and until 2001 were done with a linear aerospike configuration (Sutton, 2005).

The aerospike is known to have performance advantages over the conventional bell nozzle, particularly at off-design conditions. The altitude compensating effects of the aerospike design yield significant improvements in thrust at low altitude (Ruf \& McMonnaughey, 1997).

Thrust vectoring control by some means is required to maintain flight trajectory and Erickson (1997) found thrust vectoring of a linear-type aerospike nozzle through differential throttling to be advantageous to gimbaling of the aerospike structure. Little if any research has been conducted in the past on thrust vectoring methods for annular aerospike nozzles. Thus, thrust vectoring research as well as hybrid rocket motor test capability at California Polytechnic State University, San Luis Obispo has provided an ideal setting to evaluate the thrust vectoring potential of the annular aerospike nozzle.

\section{Research Objectives}

The primary objective of this thesis is to evaluate the thrust vectoring performance of a hole-type compound aerospike nozzle. In order to be deemed effective, a thrust-vectored nozzle must produce a turn angle equivalent to a $10^{\circ}$ gimbaling of the thrust. 


\section{Facilities and Equipment}

\section{Engines Lab}

The engine test facility in Engineering Building 13 at Cal Poly is equipped with a thrust vectoring test stand designed and developed during the early 1990s under grants from the NASA Dryden Flight Research Center. The facility has been upgraded and now accommodates both hot-fire testing and cold-flow testing. Clean, dry air at ambient temperature is used for testing, termed "cold flow", and supplied to the test stand under pressure. Cold flow was used exclusively for tests reported in this thesis.

Extensive testing and calibration have been done during previous experiments (Rossi, 1994) proving the stand to be quite accurate for measuring forces and moments. Table 1 lists the measured forces and moments with their corresponding measurement error as well as the calculated pitch and yaw angles with their respective error values. Calculations showing the derivation of the forces and moments found in the Table 1, along with the physical dimensions of the test stand used for the calculations may be found in Rossi (1994).

Table 1. Error in test stand measurements.

\begin{tabular}{|l|l|}
\hline Force & Error in force \\
\hline$F_{x}$ & $+/-0.20 \mathrm{lbf}$ \\
\hline$F_{y}$ & $+/-0.13 \mathrm{lbf}$ \\
\hline$F_{z}$ & $+/-0.34 \mathrm{lbf}$ \\
\hline Moment & Error in moment \\
\hline$M_{x}$ & $+/-1.81 \mathrm{in}-\mathrm{lbf}$ \\
\hline$M_{y}$ & $+/-2.20 \mathrm{in}-\mathrm{lbf}$ \\
\hline$M_{z}$ & $+/-0.52 \mathrm{in}-\mathrm{lbf}$ \\
\hline Angle & Error in angle \\
\hline$\delta_{\text {pitch }}$ & $\pm 0.5^{\circ}$ \\
\hline$\delta_{\text {yaw }}$ & $\pm 0.5^{\circ}$ \\
\hline
\end{tabular}




\section{Rapid Prototype Manufacturing}

The rapid-prototype, or $R P$, process used to manufacture the test nozzle presents certain restrictions and limitations. Firstly and most immediately obvious is the resolution of the rendering of the models. The RP machine extrudes a small bead of molten ABS plastic as it builds each layer of the model. In particular, areas of high curvature make the layer thickness obvious. The rough surface finish of the models introduces small flow perturbations that are visible in Schlieren photographs. Another less noticeable result of the RP process is porosity, which can weaken the models and allow air to flow through the walls. The porosity must be taken into consideration when designing parts with thinsection features or small details. During testing, several instances of mechanical failures of the ABS models occurred.

\section{Flow Visualization/Schlieren}

For flow visualization, a two-mirror color Schlieren shadowgraph apparatus was used. It was found that a red-green filter provided the best images in terms of appearance. When carefully calibrated color Schlieren may be used for quantitative measurement, however, it should be noted that the Schlieren images used in this thesis were taken at different times under different conditions and are for qualitative flow visualization only.

Through most of the early testing, Schlieren video was recorded onto VHS tape by way of video camera. Still images were then captured from the VHS video recording using computer video processing hardware and software. Near 
the end of the low-pressure testing phase, a high-definition digital video camera became available for capturing Schlieren images. The high definition camera provides much higher resolution images than the VHS-based system. The high definition camera provided most of the images presented in this thesis. Note that in each compound aerospike nozzle Schlieren photograph, a black radial line has been superimposed onto the photograph to indicate the axis of symmetry of the secondary port. The axial location of the superimposed line is somewhat arbitrary, however it is placed as close axially as possible to the secondary port axis of symmetry within the resolution that the word processing software would allow.

\section{Air Supply}

A 75 horsepower Ingersoll-Rand air compressor charges two large, outdoor holding tanks to 125 psig. The tanks provide approximately 2000 cubic feet of volume. The pressurized supply air is them piped into the test lab. Here, it passes through a shut-off valve then into an ASME specification orifice flow meter calibrated to measure flow rate passing into the test stand. Air flow into the test stand is throttled by a servo-controlled ball valve. The servo-controlled ball valve is in turn controlled by computer. Figure 1 shows layout and components of the supply air system. 


\section{Test Stand}

Once through the electronic ball valve, supply air enters the test stand.

The test stand is instrumented with six miniature tension-compression load cells. Three load cells are oriented axially and three load cells are oriented radially to produce three force measurements and three moment measurements.

Significant effort has been made to decouple the test stand from the inlet air pipes through the use of externally pressurized bellows couplers and a specially designed inlet plenum to eliminate momentum and pressure effects of the supply air flow. The test stand development effort resulted in a patent on the test stand (Carpenter \& Gerhardt 1998). The plenum and test stand are shown in Figure 2 and the six-component thrust stand is shown in Figure 3.

\section{Data Acquisition}

Pressure transducers and force transducers on the test stand are monitored by a Fluke Helios Plus Data Acquisition System. A computer records and stores these measurements. The raw data files are post-processed by Microsoft Excel macros written and refined during years of previous experiments to produce meaningful results. The output of the Excel macros are the results reported in this thesis. 


\section{Testing Procedure}

A strict procedure was developed to test nozzles safely. Before any air is flowed, condensed moisture is drained from the holding tanks to prevent it from entering the test lab. Then, the servo ball valve is powered on as well as the data acquisition system and computer. Once the control equipment is running and the electronic valves are verified to be closed, the shutoff valve is opened allowing pressurized air to enter the system. Next, a test nozzle is mounted in the test stand and secured with four set screws. Immediately before the servo ball valve is activated, the computer data collection software is initialized to collect baseline measurements for later comparison. Now the servo-controlled ball valve is opened, allowing supply air to flow through the nozzle. Data is collected for 20-30 seconds at a rate of one data point per second across all channels after pressure stabilizes to allow enough readings for good averaging. The data collection is stopped just before the electronic valve is closed, shutting off air flow. Additional detail is documented in cold-flow testing done by Rossi (1994). 

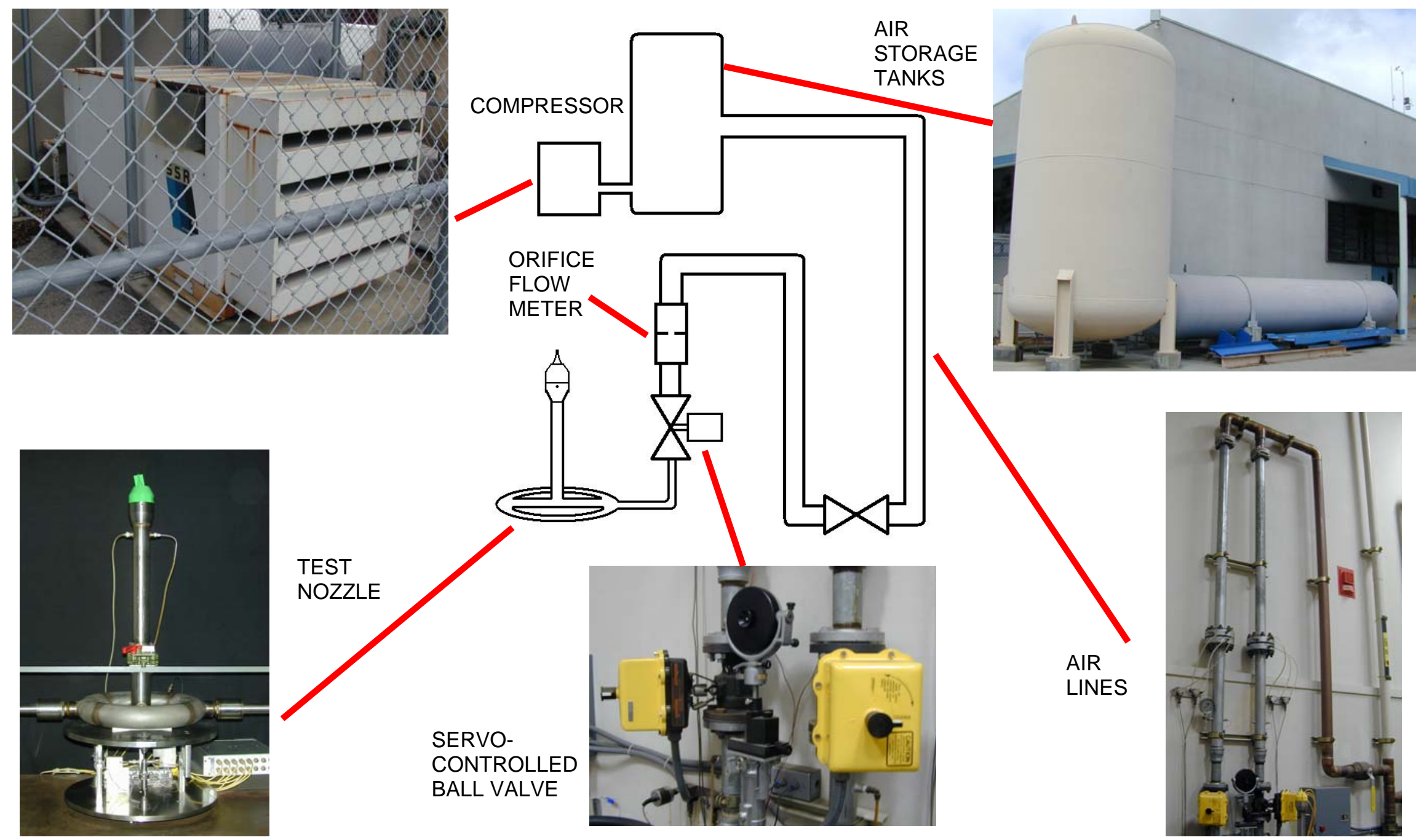

Figure 1. Layout of supply air system showing individual components. 


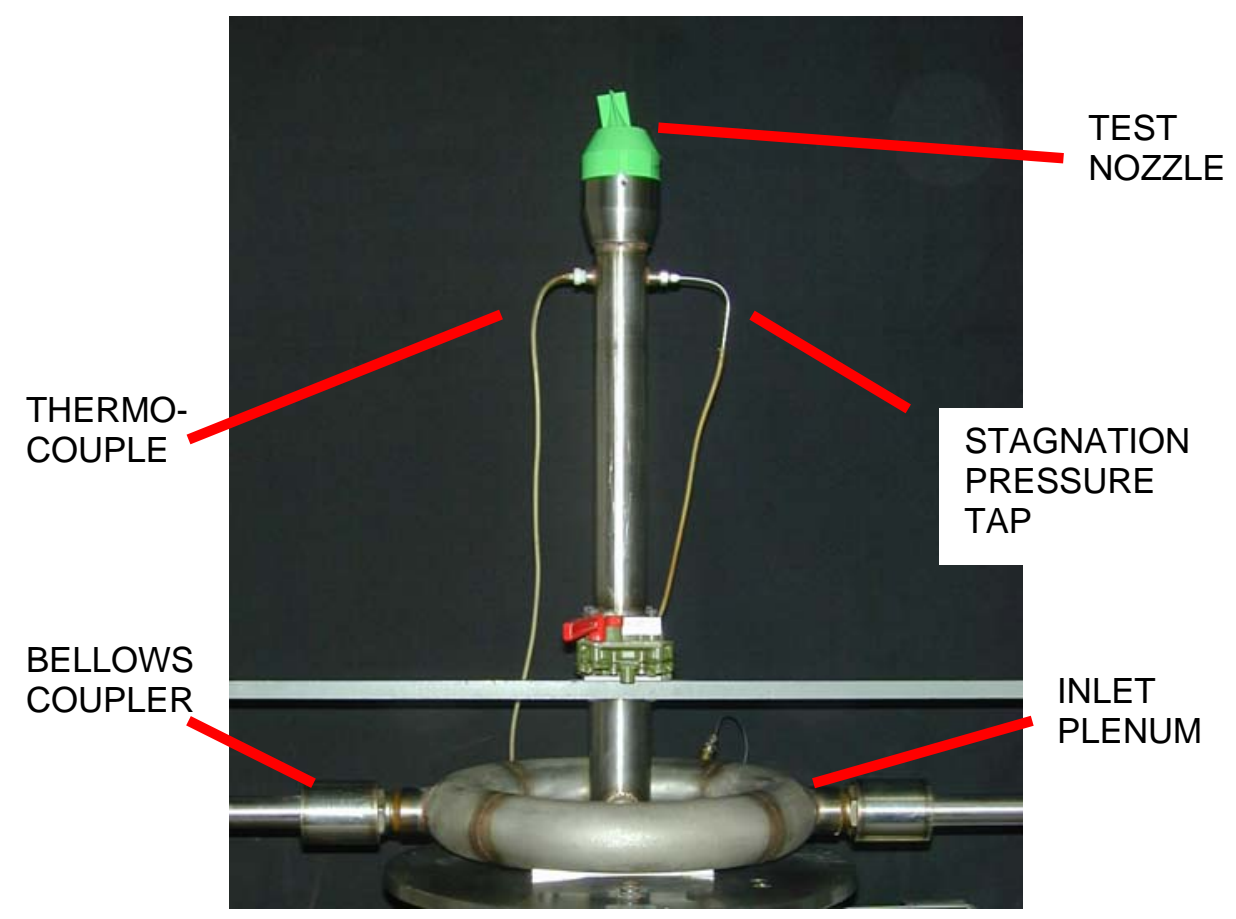

Figure 2. Test stand showing bellows, plenum, and a test nozzle mounted. Just below the nozzle can be seen stagnation pressure and temperature probes.

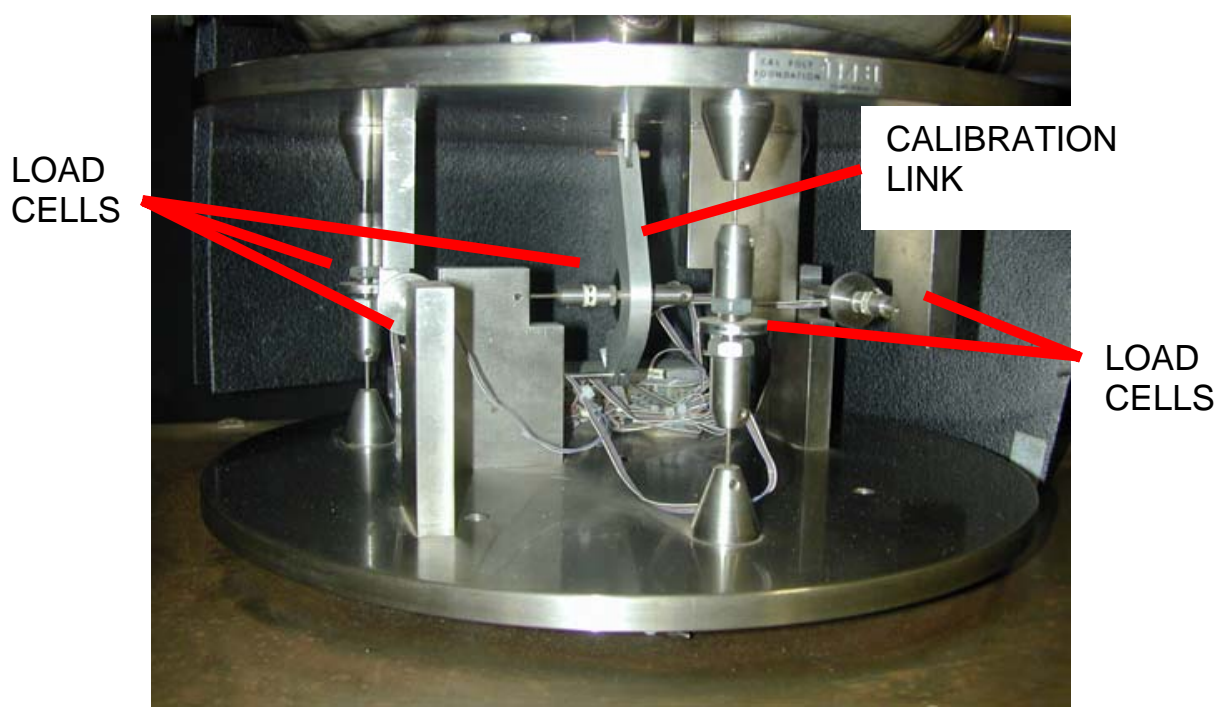

Figure 3. Load cells at base of test platform. Nozzle and plenum are supported entirely by these load cells. Hanging from the center can be seen a link from which weights are hung for calibration. 


\section{Nozzle Design}

\section{Aerospike Design/Theory}

The specific geometry of the aerospike profile is governed by the expansion of the supersonic exhaust from the nozzle. A Fortran computer program was developed by NASA in 1964 to determine the aerospike crosssection profile and published in a technical memorandum (Lee \& Thompson, 1964) and used herein. The program utilizes simplified one-dimensional isentropic Prandtl-Meyer wave expansion concepts. The program generates a list of radial and axial coordinate points defining the aerospike nozzle throat lip angle and aerospike cross-section profile from eight input parameters. The details of the Fortran program are described at length in the NASA technical memorandum. Two additional examples of aerospike cross-section approximation can be found by Rao (1961) and Greer (1960), which use similar techniques.

The aerospike nozzles used in these experiments were arbitrarily scaled to be of somewhat similar overall size to fit the test stand. The aerospike nozzles presented in this thesis are described by a dimensionless characteristic termed "nozzle pressure ratio" (NPR). Nozzle pressure ratio is the ratio of chamber pressure to ambient pressure. During data collection the NPR value was recorded as "Right NPR" to indicate it as being the NPR value recorded for the right hand inlet plenum of the dual plenum capable test stand. Since only the right hand inlet plenum was utilized during testing, "Right NPR" will simply be referred to as "NPR". 
In this thesis, all the nozzles tested were designed to operate at atmospheric pressure. Thus, if a nozzle is described as having a nozzle pressure ratio of 6 (i.e., NPR6), it is a nozzle designed for ideal operation at atmospheric pressure, a chamber pressure of 6 atmospheres and the exhaust flow is fully expanded to atmospheric pressure. Three NPRs were chosen for testing: NPR6, NPR20 and NPR50. NPR6 was chosen to provide a nozzle that could be tested at full design pressure of around $88 \mathrm{psig}$. Parenthetically, the large aerospike throat area of the NPR6 nozzles proved to be at the upper flow rate limit of the flow bench. The NPR20 design was chosen to provide preliminary data for future high-pressure and hot-fire testing planned during later phases of the STTR. The NPR50 was chosen to share the design parameter of solid-fuel aerospike rocket flight tests done by Trong Bui from NASA's Dryden Flight Research Center in March, 2004 (NASA 2004). The highest test NPR value recorded during testing was approximately 7.7 and thus the NPR20 and NPR50 nozzles are considered to be operating at over-expanded conditions. Technical drawings of the test nozzles are included in Appendix C.

\section{Thrust Vectoring Design}

Initial thrust-vectoring experiments with gimbaled aerospike nozzles (Rohlik, 2008) showed that the addition of fins to the aerospike were required for gimbaling to produce effective thrust vectoring. However, the annular geometry of the aerospike nozzle design makes thrust vectoring by gimbaling a finned aerospike significantly more complex than gimbaling a conventional nozzle. The 
support of the aerospike in particular presents a challenge due to high mechanical and thermal stresses. A non-gimbaled aerospike would avoid these complexities and it was felt that a compound aerospike nozzle formed by the addition of a secondary port would provide a more effective and simple solution, and further tests were conducted. 


\section{Initial Testing}

\section{Initial Hole-Type Compound Aerospike Nozzle}

Shown in Figure 4 is a diagram to clarify the terms that will be used to describe the compound aerospike nozzle geometric features.

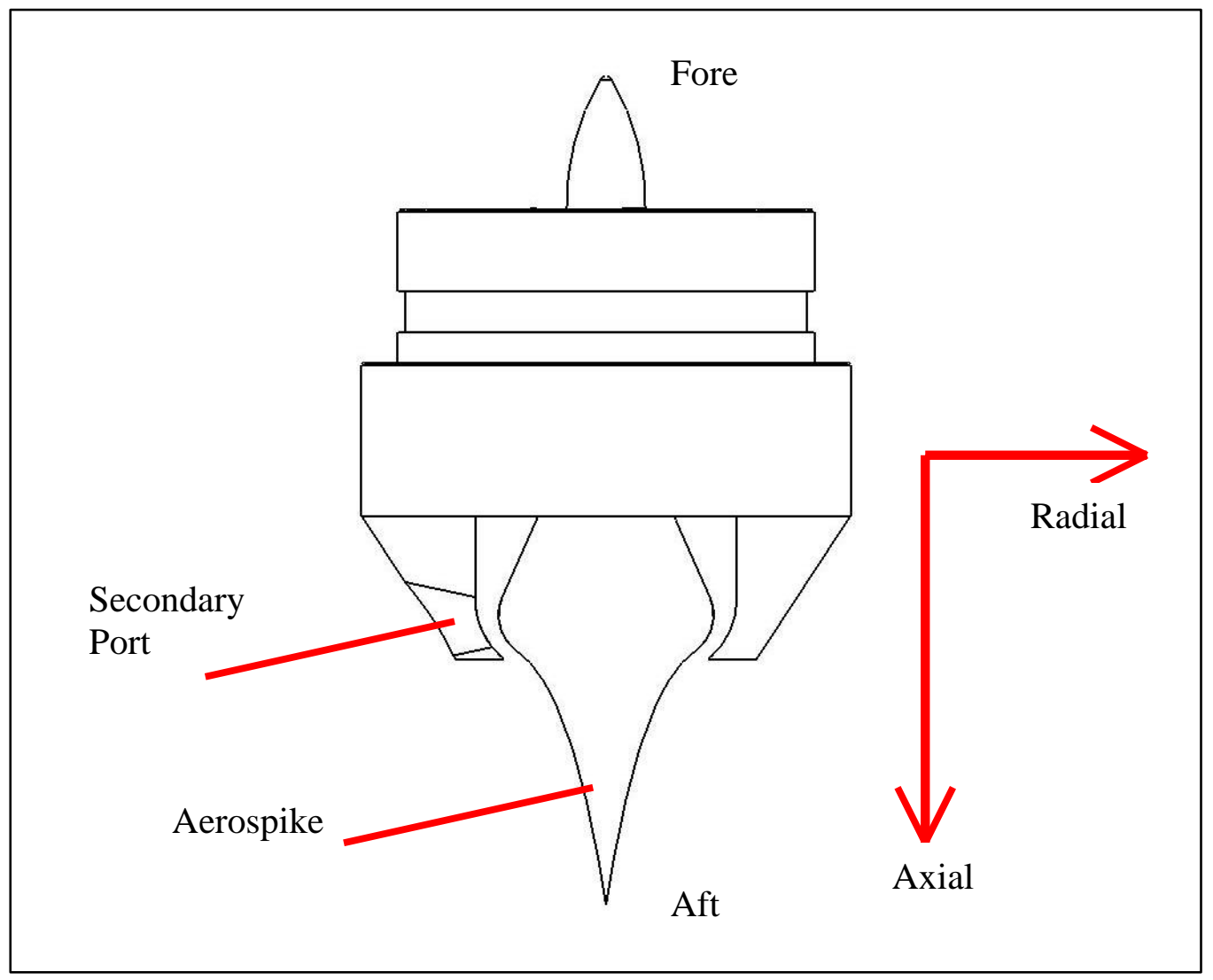

Figure 4. Diagram of terms describing compound aerospike nozzle geometry.

The initial configuration of hole-type compound aerospike nozzle, named "NPR20 Hole", is shown in Figure 5. The axial location and geometry of the secondary port features were chosen somewhat arbitrarily. A Schlieren photograph and a cross-section drawing of NPR20 Hole are shown in Figure 6. The secondary port is axisymmetric with its central axis oriented radially with a 
$3.1^{\circ}$ divergence half-angle. A technical drawing of NPR2O Hole is included in Appendix B to show geometric details of the nozzle.

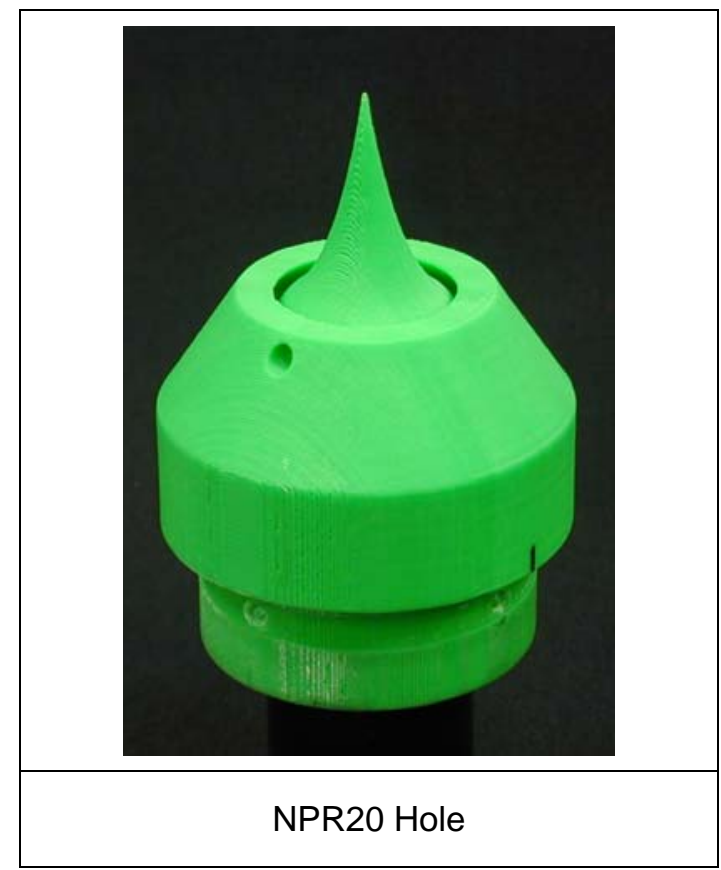

Figure 5. Initial hole-type compound aerospike nozzle configuration.

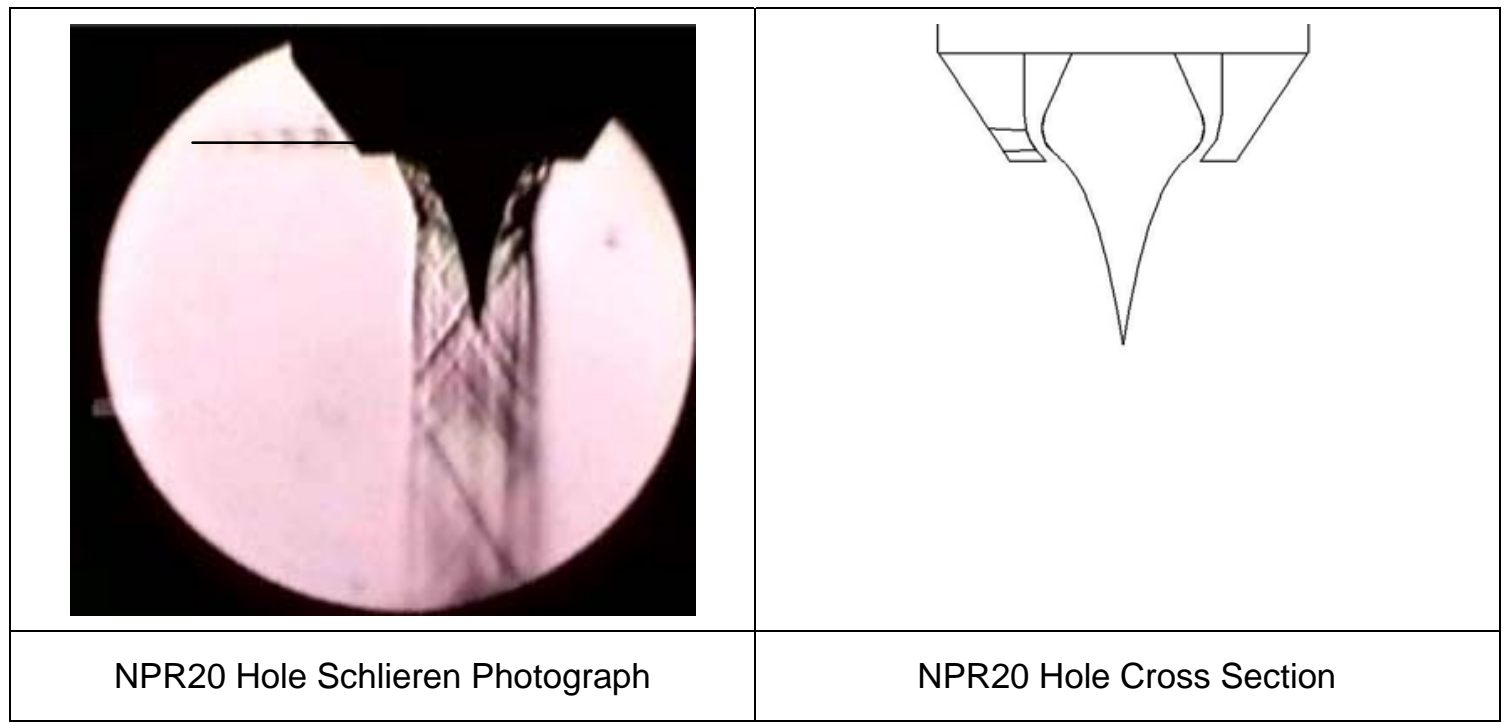

Figure 6. "NPR20 Hole" Schlieren photograph and cross-section drawing represents the initial configuration of hole-type aerospike compound nozzle. Secondary port is a $3.1^{\circ}$ half-angle nozzle. 
Visible in the Schlieren photograph of Figure 6, the secondary port is experiencing supersonic flow as evidenced by the pattern of shock waves. NPR20 Hole produced approximately $3.6^{\circ}$ of resultant turn angle, which is well short of the $10^{\circ}$ required for effective thrust vectoring. The resultant turn angle is calculated by the vector sum of forces produced by the aerospike nozzle and secondary port. Further details of resultant turn angle calculation is described in chapter seven "Nozzle Performance." It should be noted that the rough surface of the RP nozzle has introduced many small shock waves, giving the aerospike nozzle flow a "rough" appearance in the Schlieren photograph in Figure 6. 


\section{Pressure Distribution on Nozzle Wall}

In order to characterize nozzle flow approaching the aerospike throat, four test runs were performed with an aerospike nozzle equipped with ten pressure taps to measure static pressure along the outside nozzle wall. Pressure tap "P1" was located 0.036 in. axially forward of the aerospike nozzle throat lip, with each successive pressure tap approximately 0.05 in. forward from the previous. The pressure tap instrumented nozzle is shown in Figure 7. Pressure tap data are presented in Table 2 and these data are shown graphically in Figure 8. It can be observed that the static pressure measured at the nozzle wall decreases as the flow approaches the throat, which is expected as the velocity increases. 


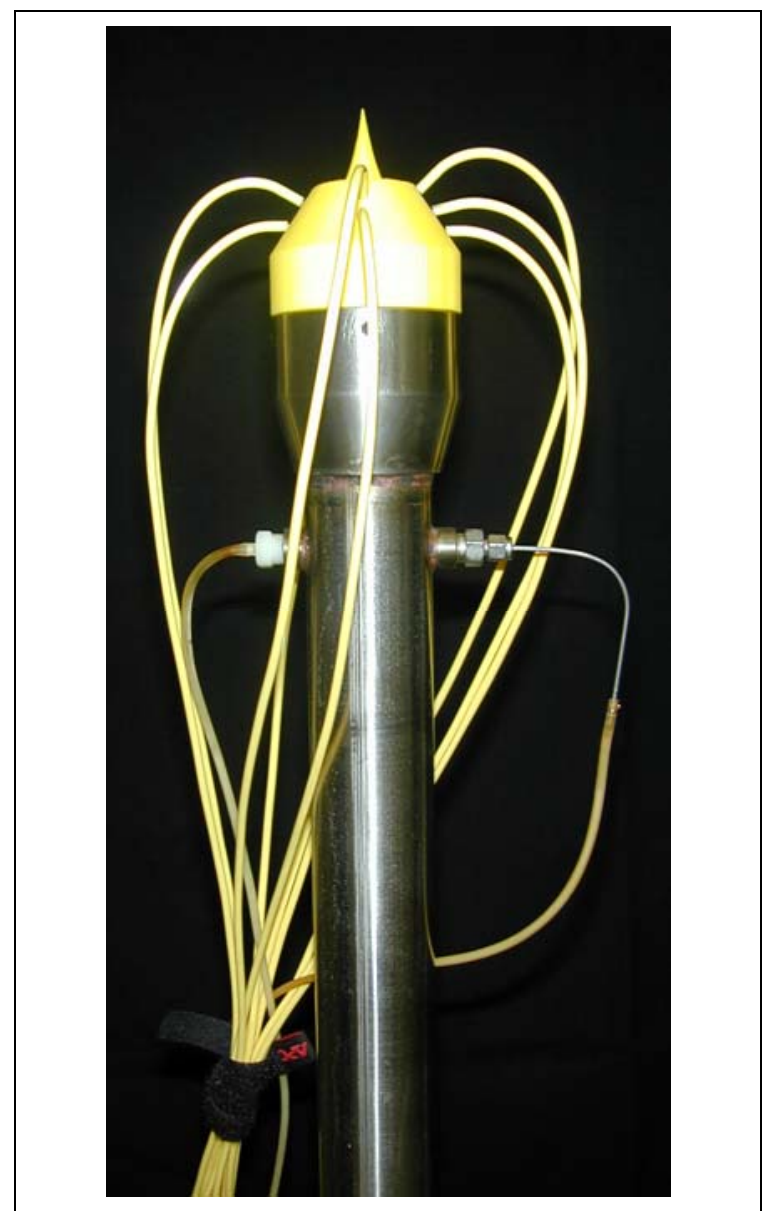

Figure 7. Pressure tap equipped NPR20 nozzle.

Table 2. Pressure distribution along nozzle wall.

\begin{tabular}{|l|c|c|c|c|c|c|c|c|c|c|}
\hline & $\begin{array}{c}\text { P1 } \\
\text { (psig) }\end{array}$ & $\begin{array}{c}\text { P2 } \\
\text { (psig) }\end{array}$ & $\begin{array}{c}\text { P3 } \\
\text { (psig) }\end{array}$ & $\begin{array}{c}\text { P4 } \\
\text { (psig) }\end{array}$ & $\begin{array}{c}\text { P5 } \\
\text { (psig) }\end{array}$ & $\begin{array}{c}\text { P6 } \\
\text { (psig) }\end{array}$ & $\begin{array}{c}\text { P7 } \\
\text { (psig) }\end{array}$ & $\begin{array}{c}\text { P8 } \\
\text { (psig) }\end{array}$ & $\begin{array}{c}\text { P9 } \\
\text { (psig) }\end{array}$ & $\begin{array}{c}\text { P10 } \\
\text { (psig) }\end{array}$ \\
\hline $\begin{array}{l}\text { Axial } \\
\text { Location (in) }\end{array}$ & 0.039 & 0.076 & 0.118 & 0.163 & 0.210 & 0.260 & 0.309 & 0.359 & 0.409 & 0.459 \\
\hline RUN \# 2105 & 58.8 & 79.6 & 80.8 & 83.7 & 84.8 & 87.3 & 87.6 & 88.2 & 89.6 & 87.7 \\
\hline RUN \# 2106 & 59.2 & 80.0 & 81.3 & 84.3 & 85.0 & 87.7 & 88.2 & 88.4 & 89.8 & 87.9 \\
\hline RUN \# 2107 & 59.4 & 80.2 & 81.0 & 84.0 & 85.2 & 87.7 & 87.9 & 88.5 & 89.9 & 87.9 \\
\hline RUN \# 2108 & 59.6 & 80.1 & 80.8 & 84.2 & 85.3 & 87.6 & 88.1 & 88.4 & 89.8 & 87.6 \\
\hline
\end{tabular}




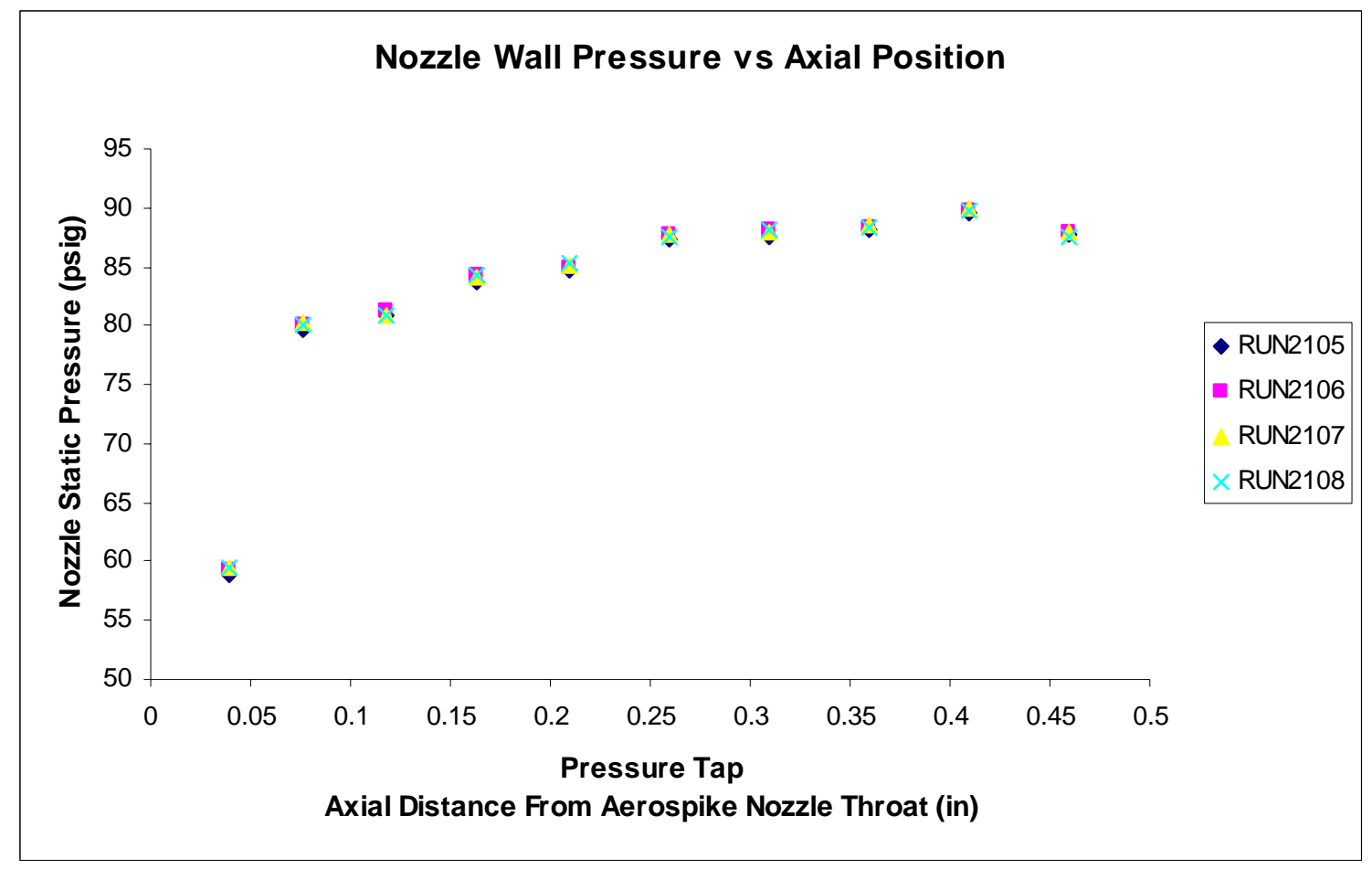

Figure 8. Nozzle Wall Static Pressure versus Axial Position Pressure Tap Results.

The absence of flow disturbances or a localized region of high pressure on the nozzle wall allows placement of the compound nozzle where geometric or other considerations allow. These pressure tap data also show that the static pressure of the flow as it approaches the throat is decreasing in relation to the total (chamber) pressure, especially nearing 0.05 in. upstream of the throat. The drop in static pressure indicates that the flow is developing kinetic energy. Chamber pressure during these tests measured about 104 psig, which translates to approximately Mach 0.57 at pressure tap "P2" and approximately Mach 0.85 at pressure tap "P1" which indicates that the flow is nearing the transonic range. It should be noted that these pressure readings are not meant to determine the actual velocity within the chamber, but instead to identify any regions of localized, unexpected high pressure (none were found). 


\section{Test Nozzles}

After initial testing showed promising results for the hole-type compound aerospike nozzle configurations, an array of test nozzles was designed. At each of the three NPR values two compound aerospike nozzles were designed and built such that one had twice the secondary port throat area of the other (0.026 in. ${ }^{2}$ vs 0.051 in. ${ }^{2}$ ), while axial location of the radially oriented central axis was held constant. All secondary ports were designed to have a $12^{\circ}$ half angle conical divergent section. Having the same secondary port geometries would allow direct comparison of the nozzles among themselves and at different NPRs. The array of compound aerospike nozzles along with the non-compound aerospike nozzle of each of the three NPR values is shown in Table 3. Schlieren photographs are shown in Figure 9, Figure 10, Figure 11, and Figure 12. Using the superimposed radial line as reference, it can be noted that the direction of the secondary port flow does not follow the secondary port axis of symmetry, and can be noted in many of the compound aerospike nozzles. The observation that the secondary port flow does not follow the axis of symmetry of the secondary port is further discussed in the Results section of this thesis.

Three NPR20 aerospike test nozzles were machined from aluminum and stainless steel. The aerospike nozzle "NPR20 Straight Metal" was made by Cal Poly ME Master Technician Jim Gerhardt, while the aerospike nozzles "NPR20 Straight Metal (Stan 1)" and "NPR20 Metal Port (Stan 2)" were fabricated by the author and are very similar to Mr. Gerhardt's. Both of the authors nozzles were made at the same time and are identical with the exception of the hole-type 
secondary port machined into the side of "NPR20 Metal Port (Stan 2)". The intention of "NPR20 Metal Port (Stan 2)" was to duplicate "NPR20 Hole 3" however, a machining error resulted in an unknown secondary port throat diameter. The secondary port throat of "NPR20 Metal Port (Stan 2) is particularly sharp and no effort was made to provide it with a radius. Photographs of the metal NPR20 test aerospike nozzles are shown in Table 4. Schlieren photographs of the three metal test aerospike nozzles are shown in Figure 13. The lack of flow perturbations caused by RP surface roughness in the aerospike nozzle flow can be noted in the Schlieren photographs of the metal nozzles. Also in the Schlieren photograph of compound aerospike nozzle "NPR20 Metal Port (Stan 2)" the axisymmetric, radial direction of the secondary port flow and the introduction of small flow perturbations into the aerospike nozzle flow can be seen. Metal nozzle results are further discussed in the Results section of this thesis. 
Table 3. Photos of test nozzles.

\begin{tabular}{|l|c|c|c|}
\hline & NPR 6 Nozzles & NPR 20 Nozzles & NPR 50 Nozzles \\
\hline $\begin{array}{l}\text { Non- } \\
\text { Compound } \\
\text { Aerospike } \\
\text { Nozzles }\end{array}$ & & & \\
\hline
\end{tabular}


Table 4. Photos of metal test aerospike nozzles
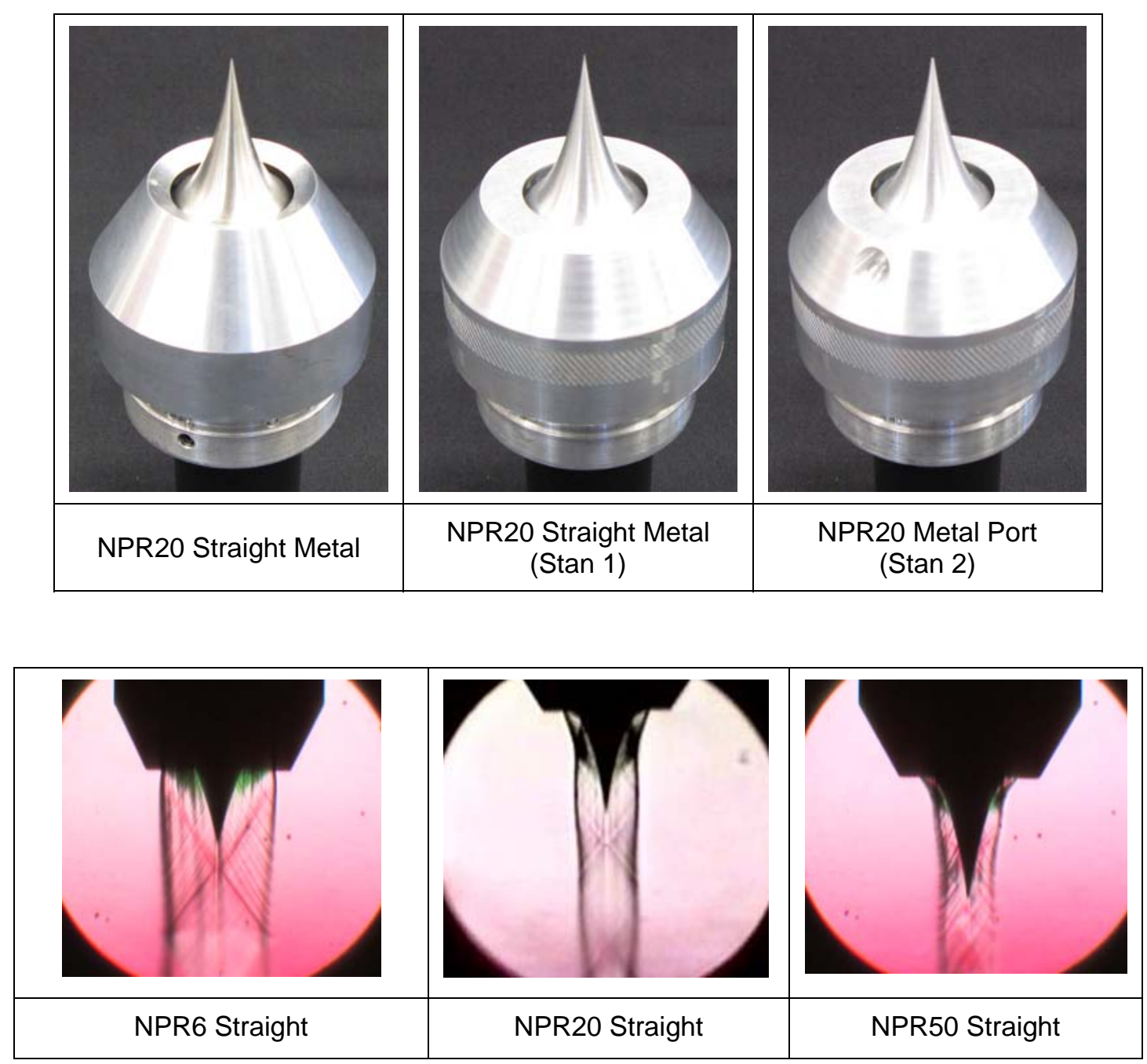

Figure 9. Schlieren photographs of non-compound aerospike nozzles. 


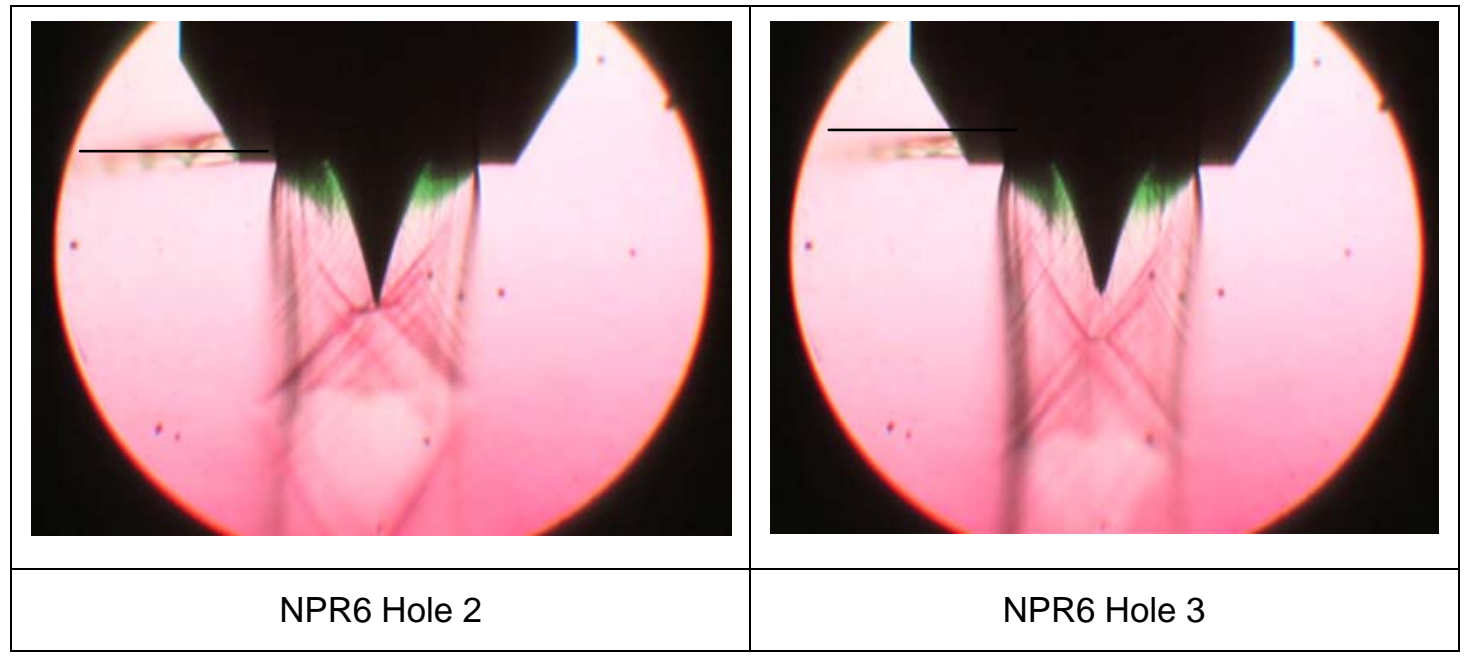

Figure 10. Schlieren photographs of NPR6 compound nozzles. Note non-radial flow direction of secondary port.

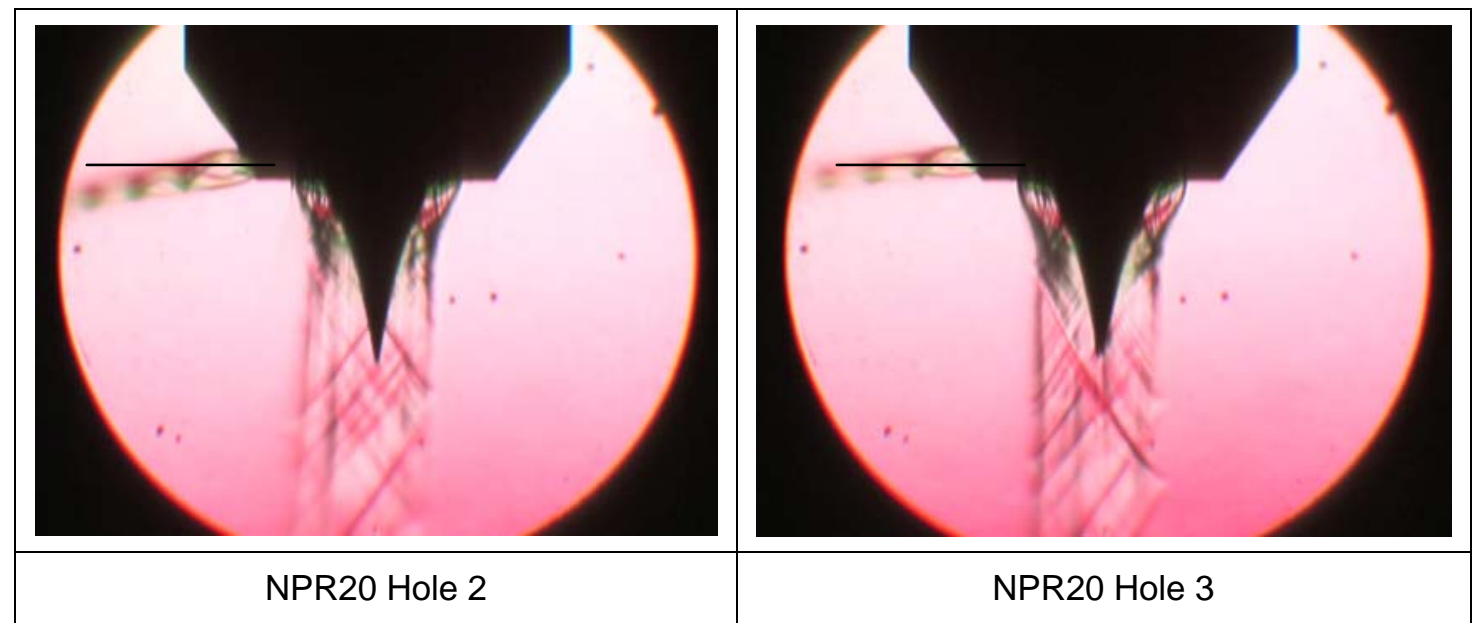

Figure 11. Schlieren photographs of NPR20 compound nozzles, no inlet radius. Note non-radial flow direction of secondary port. 


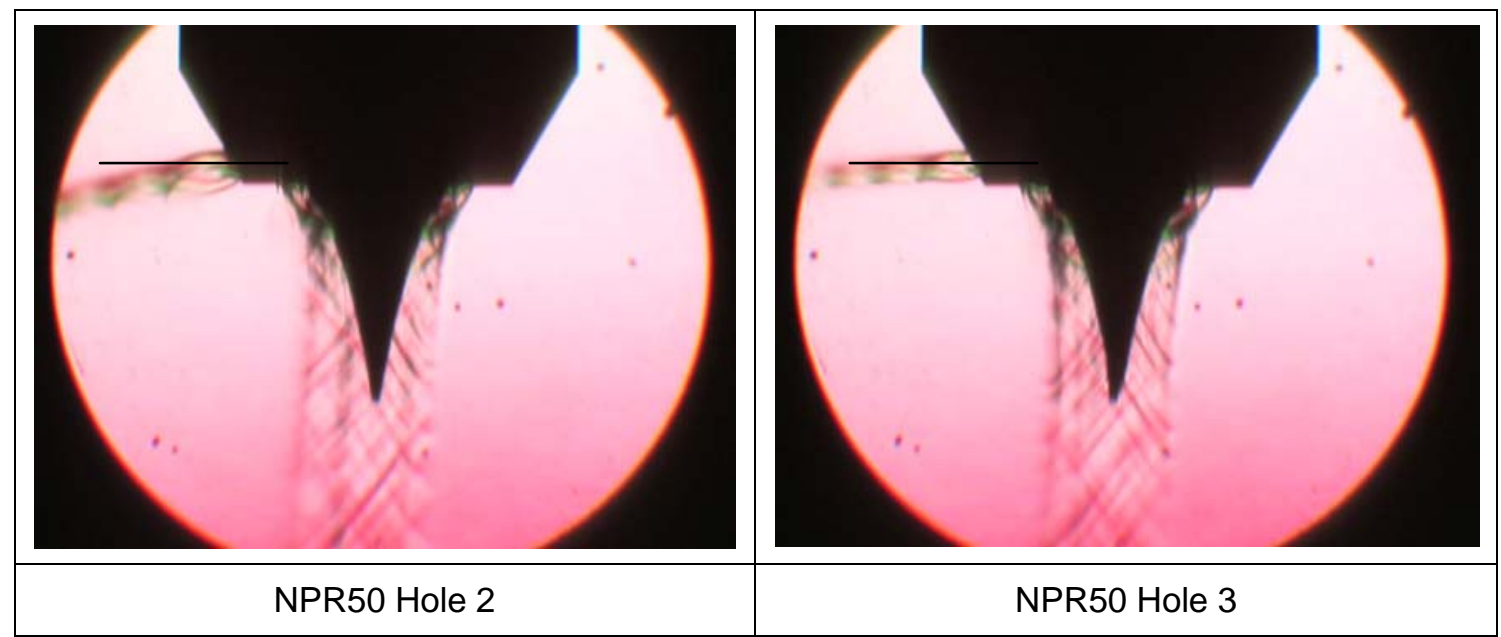

Figure 12. Schlieren photographs of NPR50 compound aerospike nozzles. Note the non-radial direction of secondary port flow.

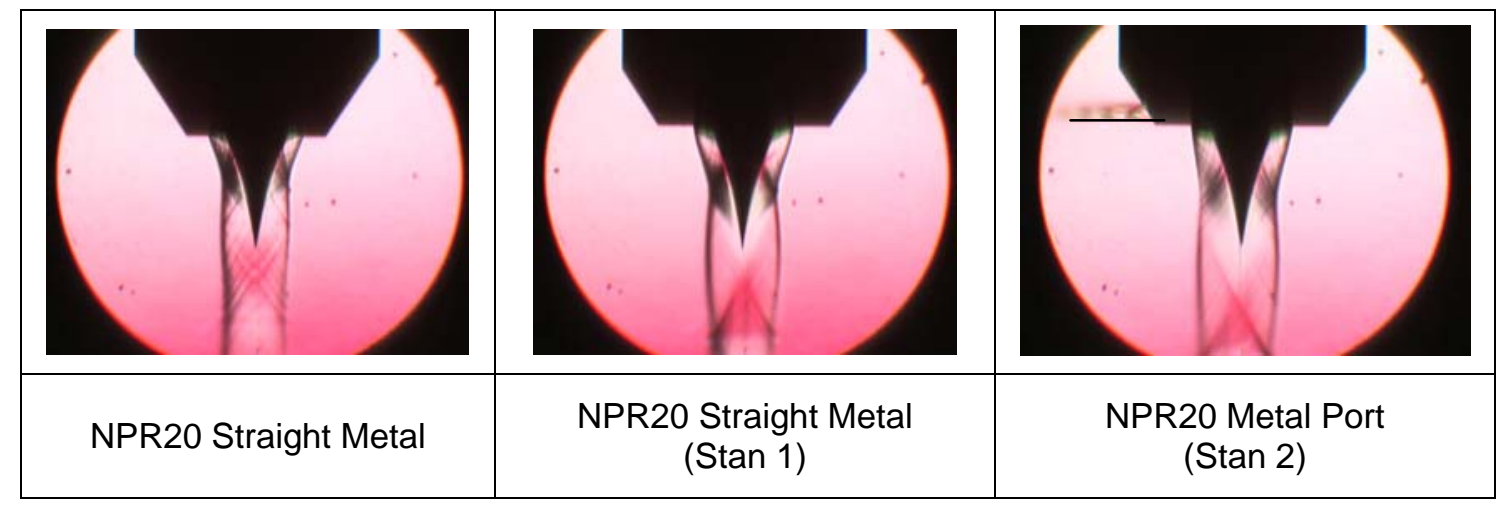

Figure 13. Schlieren photographs of NPR20 metal aerospike nozzles. Aerospike nozzle "NPR20 Straight Metal (Stan 1)" and compound aerospike nozzle "NPR20 Metal Port (Stan 2)" are of the same design and construction with the exception of the addition of a hole-type secondary port to "NPR20 Metal Port (Stan 2)".

The intersection of the secondary port and the aerospike nozzle inner wall is of particular importance as the throat of the secondary port is defined by the geometry in this location. The secondary port inlet is also formed by a sharp edge. With the addition of aerodynamic disturbances near the throat of the secondary port, it is unknown how this will affect the transonic secondary port flow. 
In order to observe the effect of minimizing the sharp inlet region of the secondary port, a set of test nozzles was made with a radius provided on the inlet of the secondary port. Nozzle "NPR20 Hole 3" was modified to have secondary port inlet radii of 0.025 in., 0.050 in., and 0.075 in. to become "NPR20 Hole 7", "NPR20 Hole 5", and "NPR20 Hole 6", respectively. The outward appearance of these compound aerospike nozzles is identical, thus individual photos have been omitted for the sake of brevity. Figure 14 shows the Schlieren photographs of the compound aerospike nozzles with secondary port inlet radii.

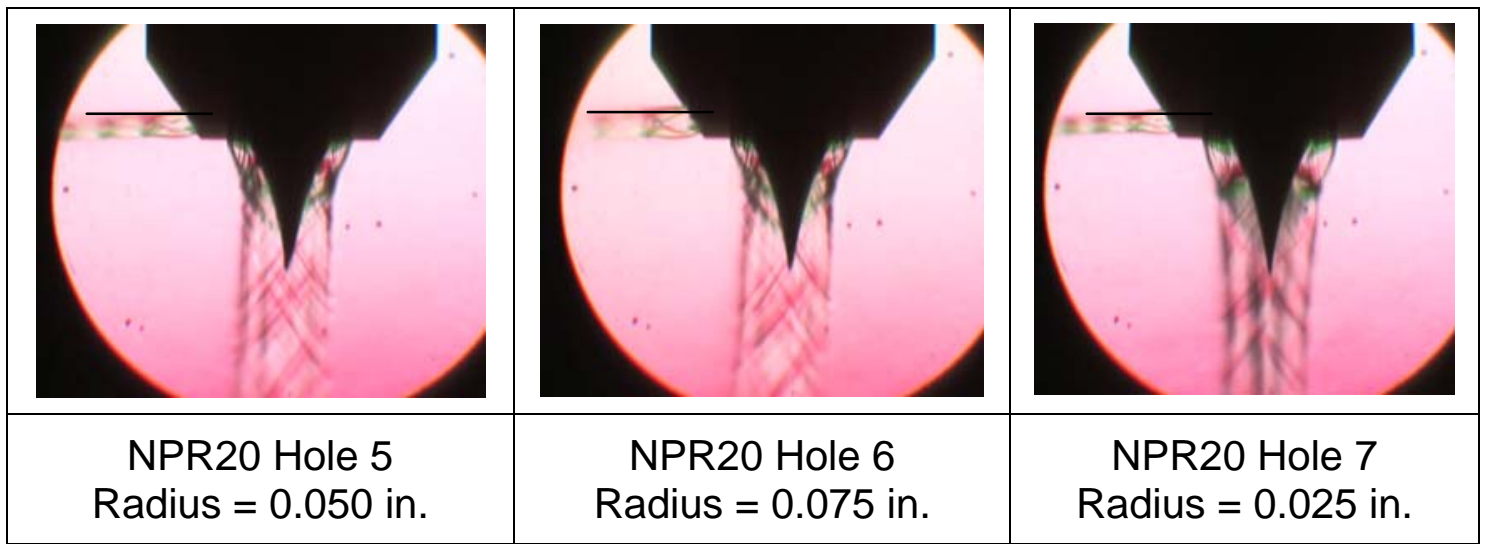

Figure 14. Schlieren photographs of NPR20 compound aerospike nozzles with secondary port inlet radii. Note improvement in radial direction of secondary port flow. 


\section{Nozzle Performance}

\section{Chamber Pressure Variations}

For each compound and non-compound aerospike nozzle, a series of tests was performed in which the servo-controlled ball valve was used to throttle the air flow into the test stand. Throttled air flow resulted in a change in nozzle chamber pressure. Five increments of chamber pressure were tested that ranged from the smallest possible flow through the servo-controlled ball valve to fully open. The results of these experiments are shown in Figure $\mathbf{1 5}$ as a graph of resultant turn angle versus chamber pressure (NPR). It should be noted that the servo-controlled ball valve positions were chosen without consideration of the resultant chamber pressure as the qualitative behavior of the compound aerospike nozzle in response to varying chamber pressure was the desired result of this experiment. 


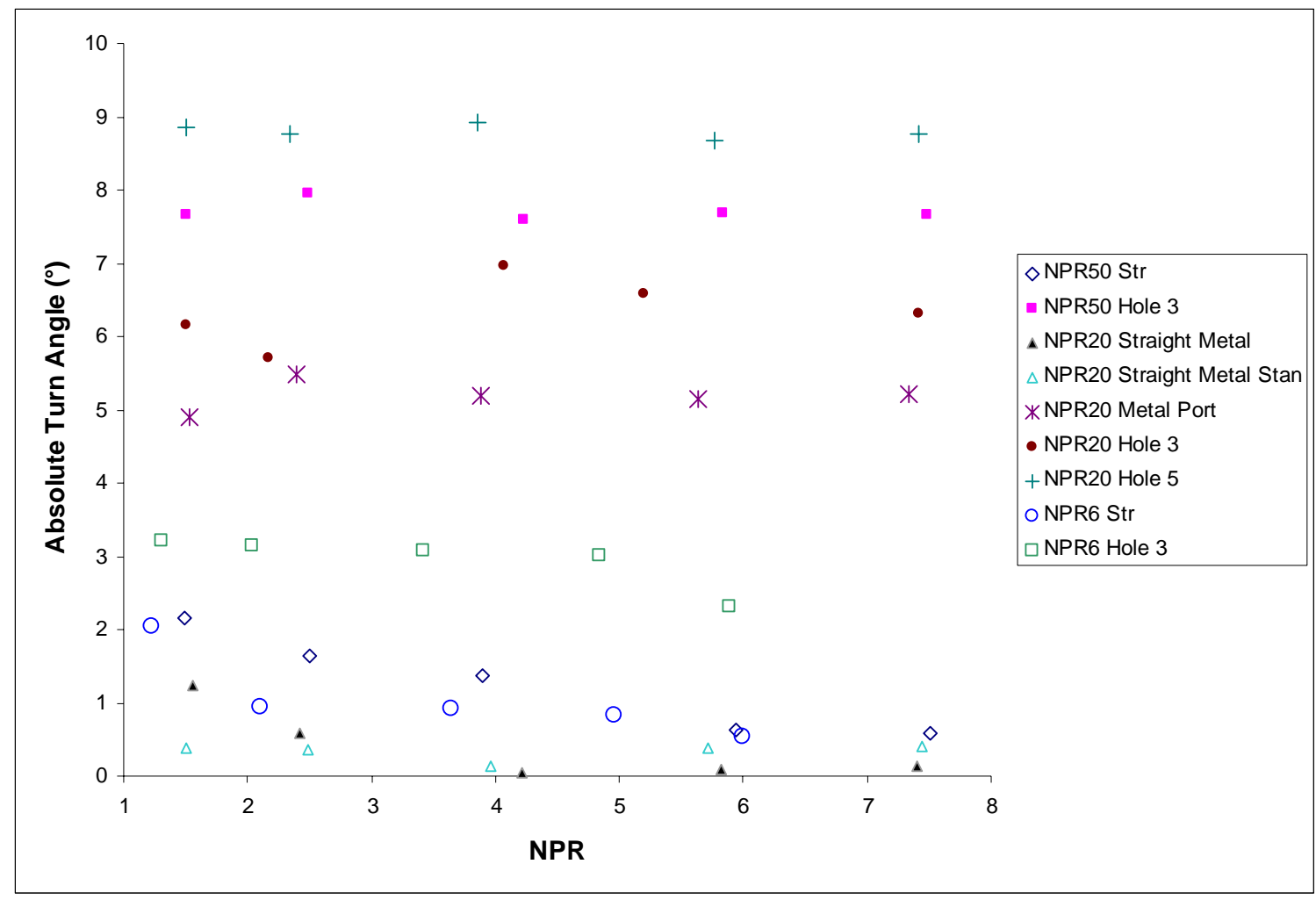

Figure 15. Absolute Turn Angle versus NPR, results of varying chamber pressure.

\section{Turn Angle Prediction}

Resultant turn angle $\left(\delta_{\mathrm{r}}\right)$ is determined by the angle of the resultant vector sum of the aerospike axial force $\left(F_{z}\right)$ and secondary port radial vectoring force ( $\left.F_{\text {vector}}\right)$ and is calculated as follows:

Equation 1. $\delta_{r}=\tan ^{-1}\left(\frac{F_{\text {vector }}}{F_{z}}\right)$

A diagram showing the orientation of the aerospike nozzles axial force $\left(F_{z}\right)$ and secondary port radial vectoring force $\left(F_{\text {vector }}\right)$ relative to the compound aerospike nozzle is shown in Figure 16. 


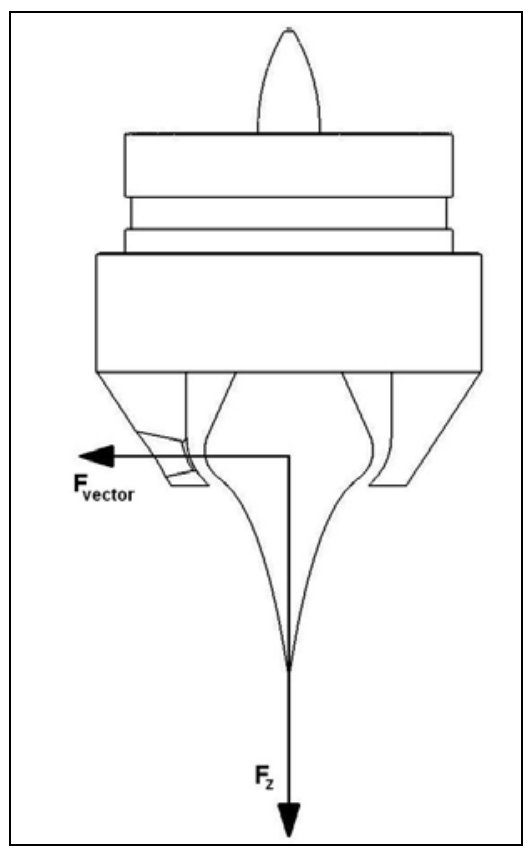

Figure 16. Diagram of compound aerospike nozzle forces (not to scale).

To estimate the resultant turn angle of the compound aerospike nozzles, the CAD models of the nozzles were used to measure secondary port throat area $\left(A_{t}\right)$ and exit area $\left(A_{e}\right)$. Using the measured areas together with the measured chamber pressure $\left(P_{1}\right)$ and chamber temperature $\left(T_{1}\right)$, the radial vectoring force produced by the secondary port $\left(\mathrm{F}_{\text {calc }}\right)$ can be calculated using the equations in Appendix $\mathrm{A}$ for each run and compared with the measured radial vectoring force $\left(F_{\text {vector }}\right)$.

Using NPR values measured during the experiment that varied chamber pressure, the results of these calculations for secondary port radial vectoring force are shown in Figure 17 through Figure 20. Similarly for the aerospike nozzle, using the throat area obtained from the CAD model the axial force produced by the aerospike nozzle $\left(F_{z}\right)$ may be calculated for the actual test NPR values that were also used in calculating secondary port radial vectoring force. 
The results of these calculations for aerospike axial force are shown in Figure $\mathbf{2 1}$ through Figure 24. Also shown in each figure is a dashed line that represents the critical pressure above which choked flow may form. The critical pressure value $(N P R=1.89)$ was also used in the calculated turn set and is the lowest NPR value used in the calculations as any lower pressure will not result in supersonic flow.

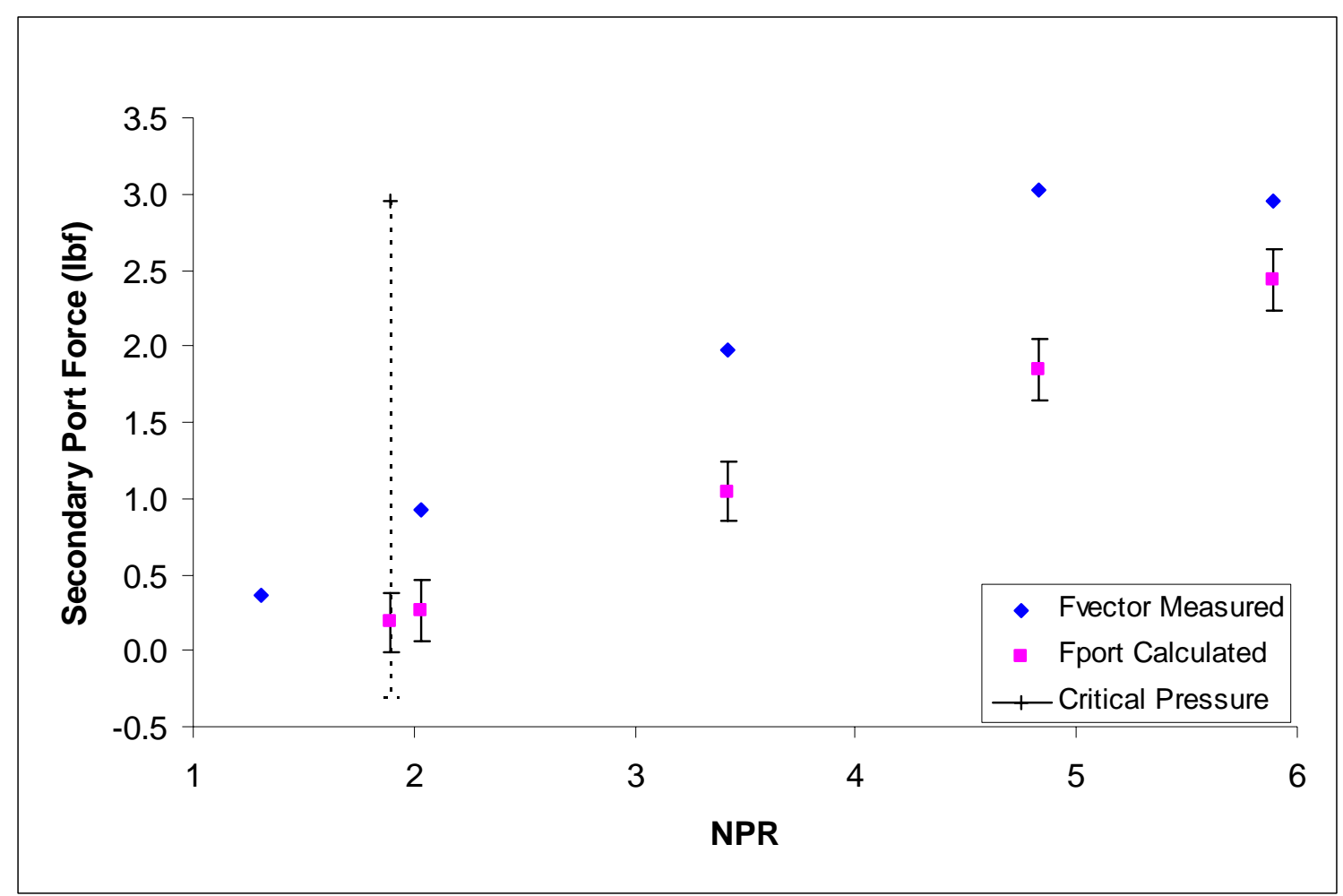

Figure 17. NPR6 Hole 3 Secondary Port Measured and Calculated Radial Vectoring Force versus NPR. 


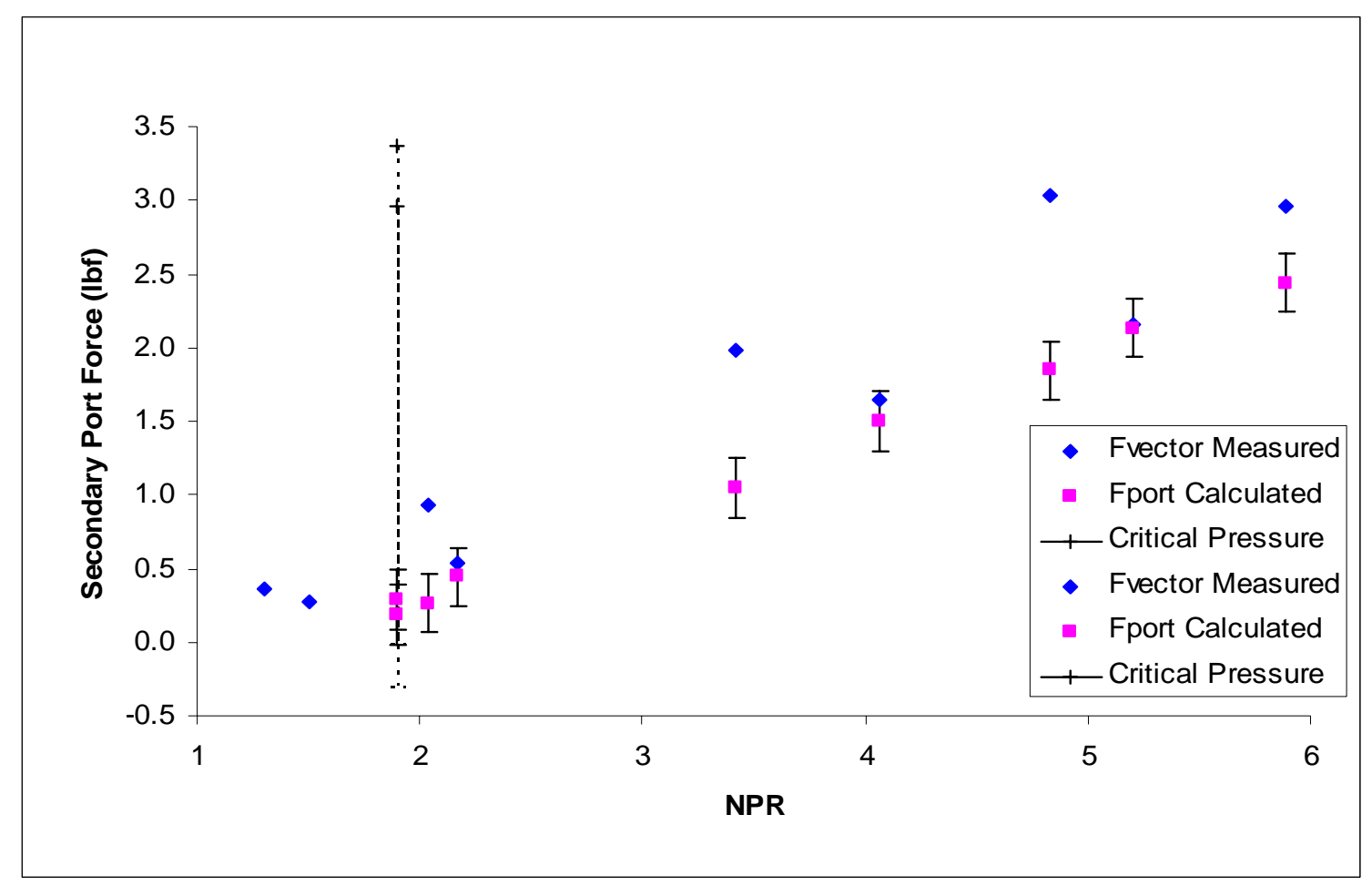

Figure 18. NPR20 Hole 3 Secondary Port Measured and Calculated Radial Vectoring Force versus NPR.

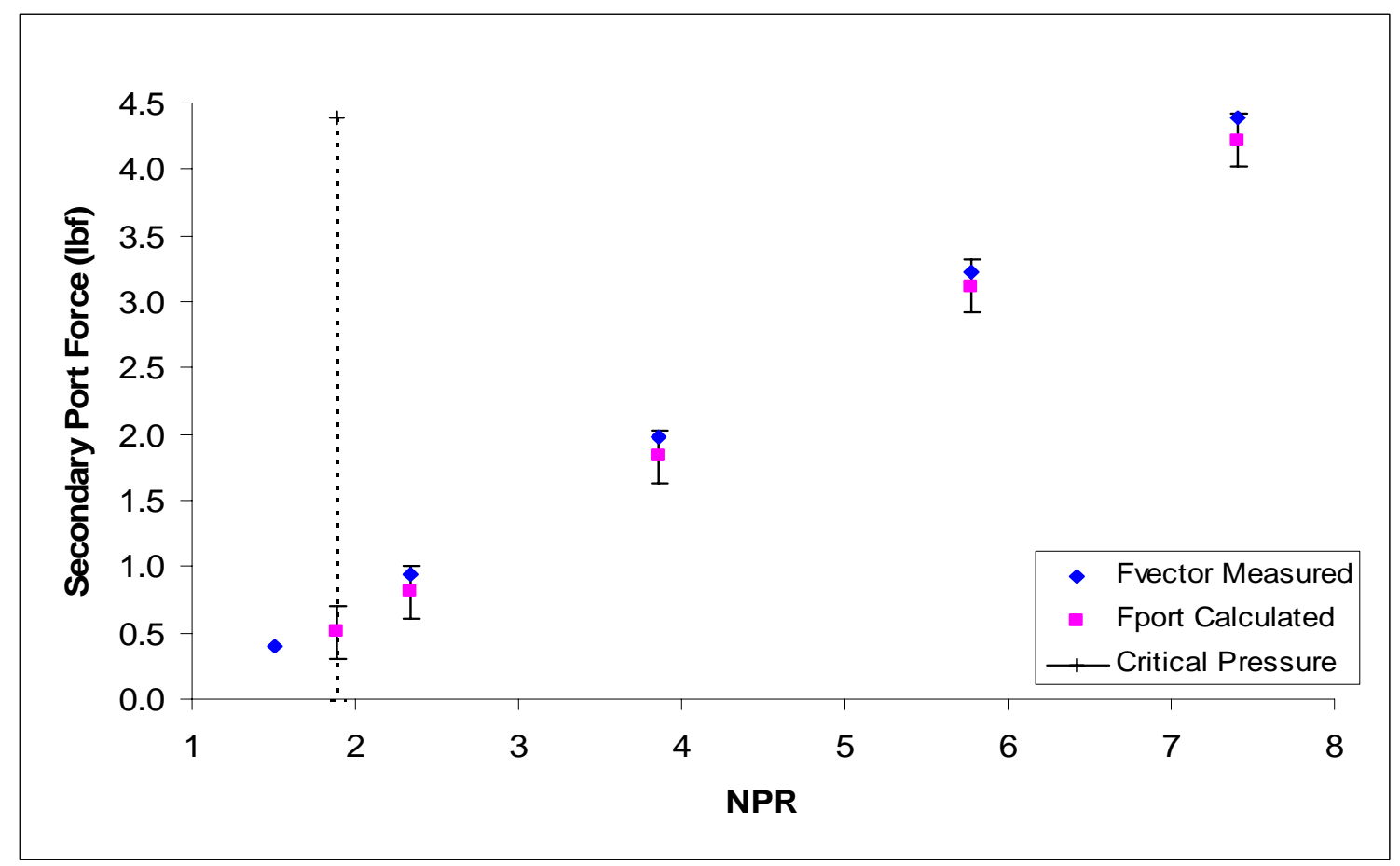

Figure 19. NPR20 Hole 5 Secondary Port Measured and Calculated Radial Vectoring Force versus NPR. 


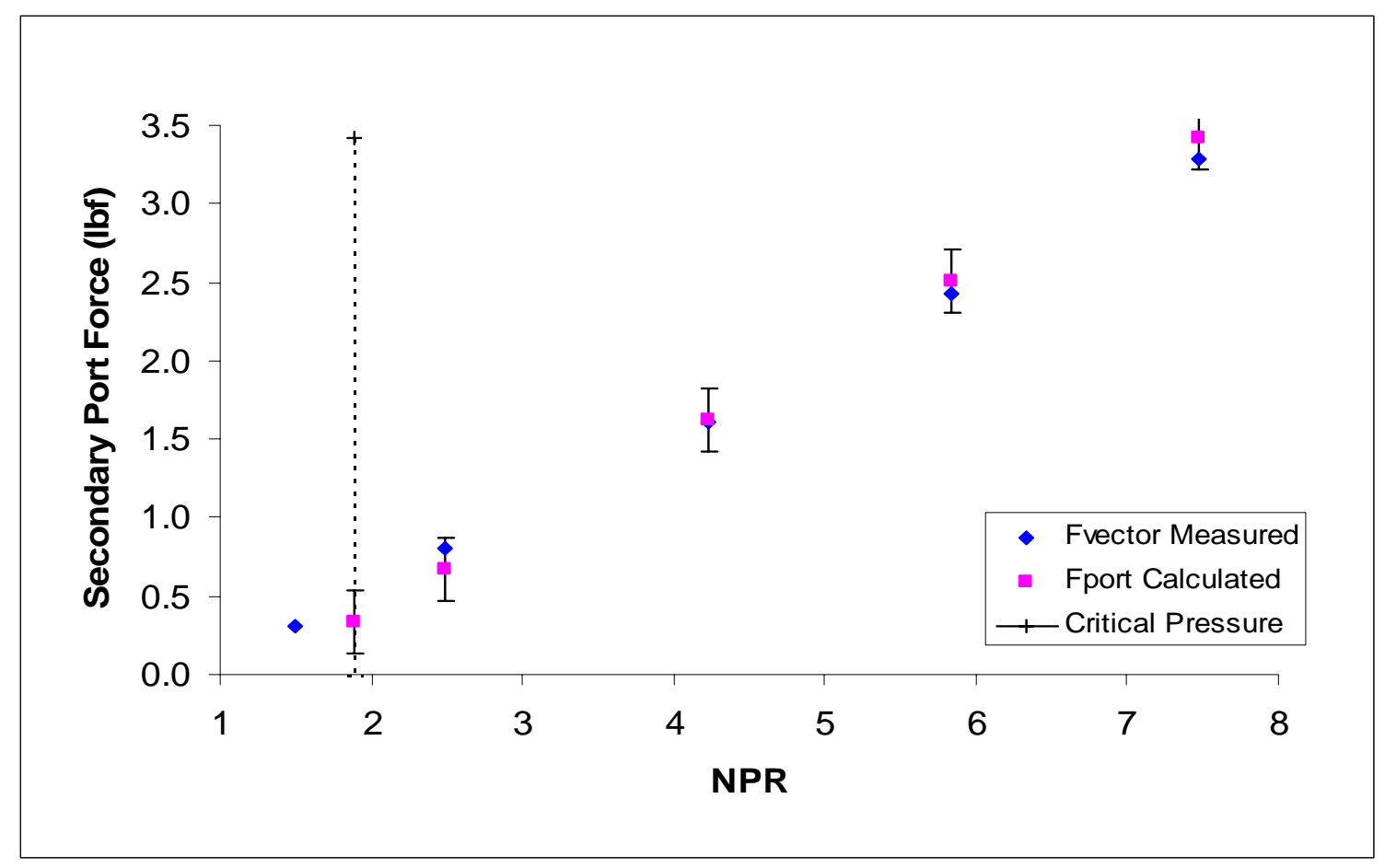

Figure 20. NPR50 Hole 3 Secondary Port Measured and Calculated Radial Vectoring Force versus NPR.

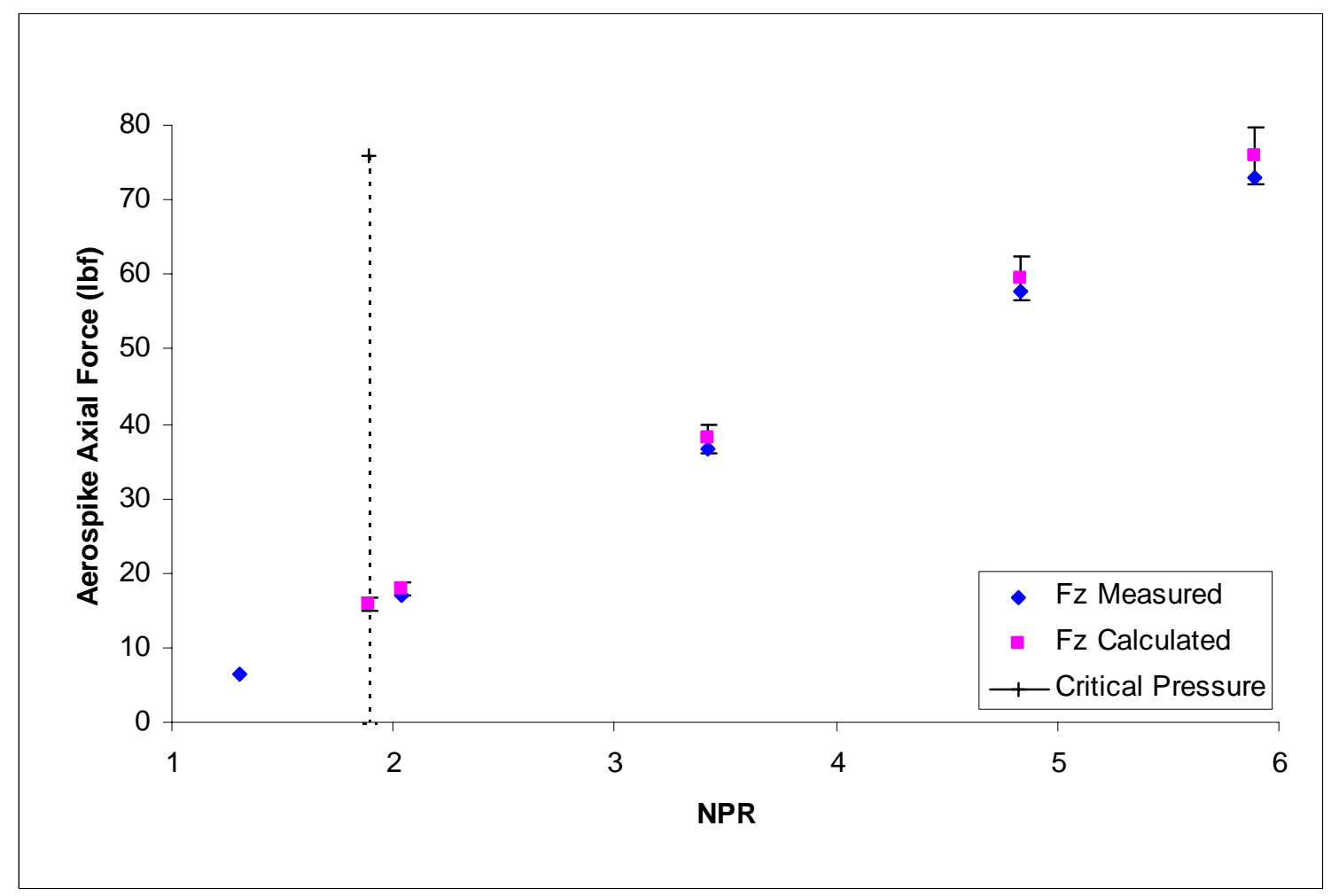

Figure 21. NPR6 Hole 3 Aerospike Nozzle Measured and Calculated Axial Force versus NPR. 


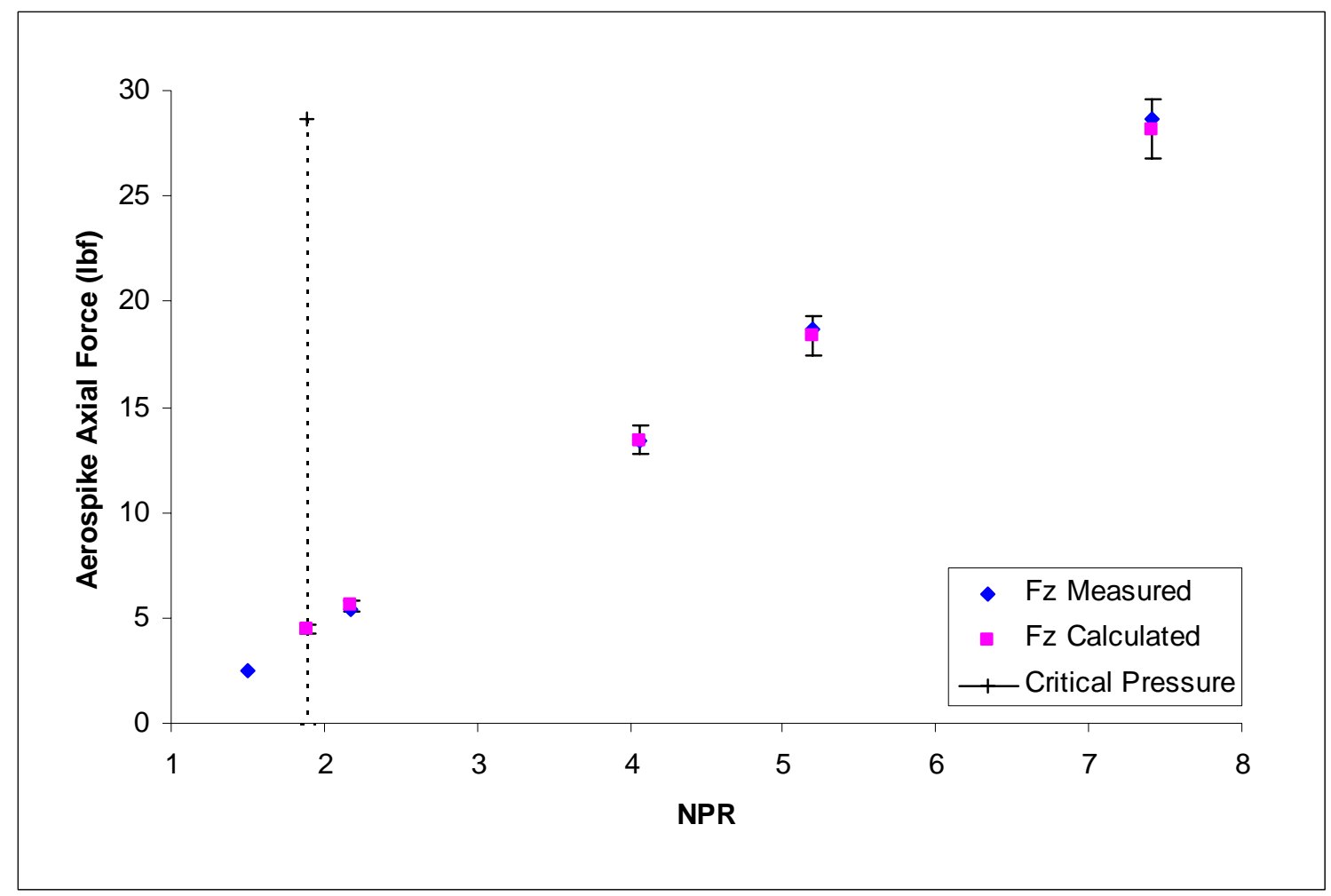

Figure 22. NPR20 Hole 3 Aerospike Nozzle Measured and Calculated Axial Force versus NPR.

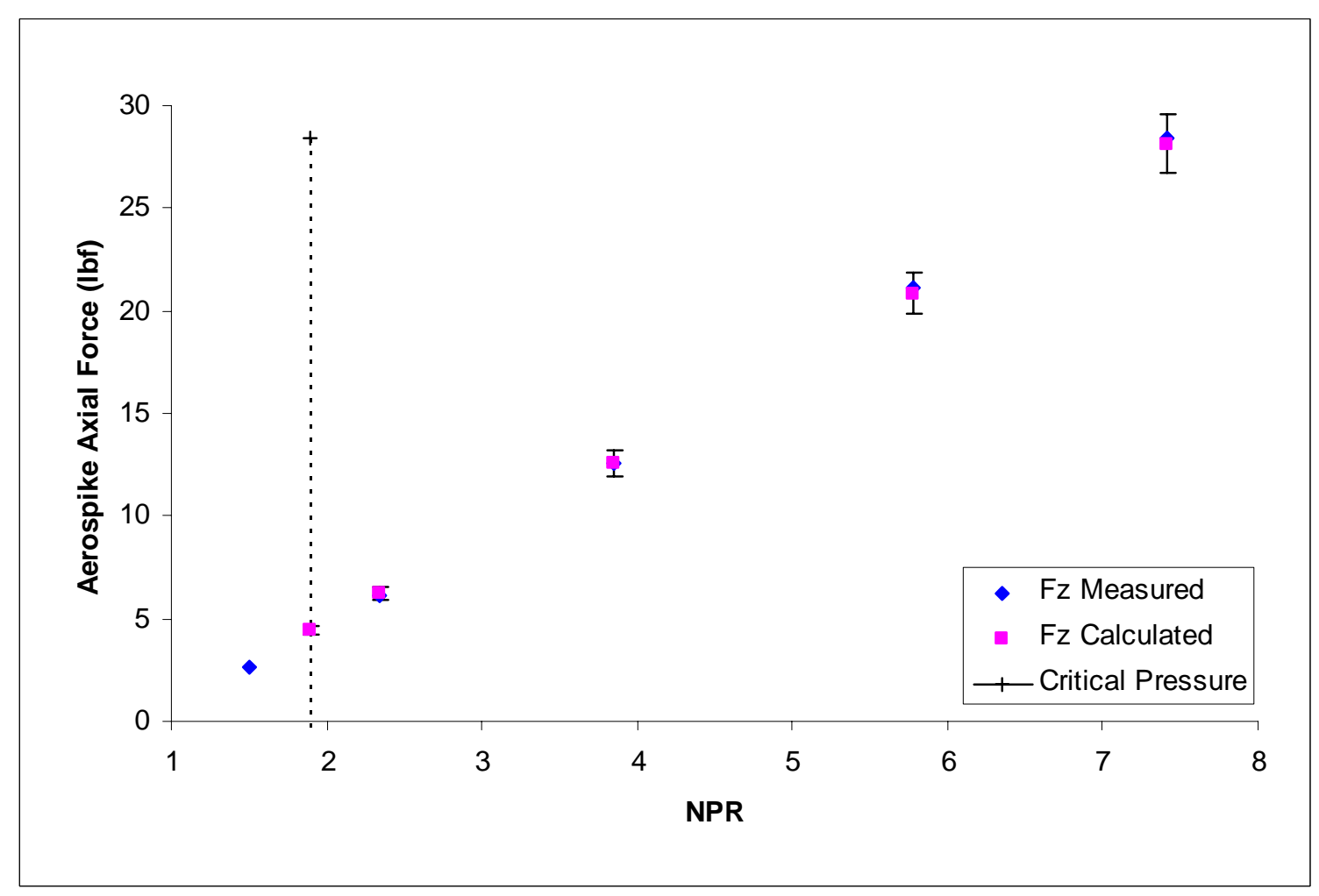

Figure 23. NPR20 Hole 5 Aerospike Nozzle Measured and Calculated Axial Force versus NPR. 


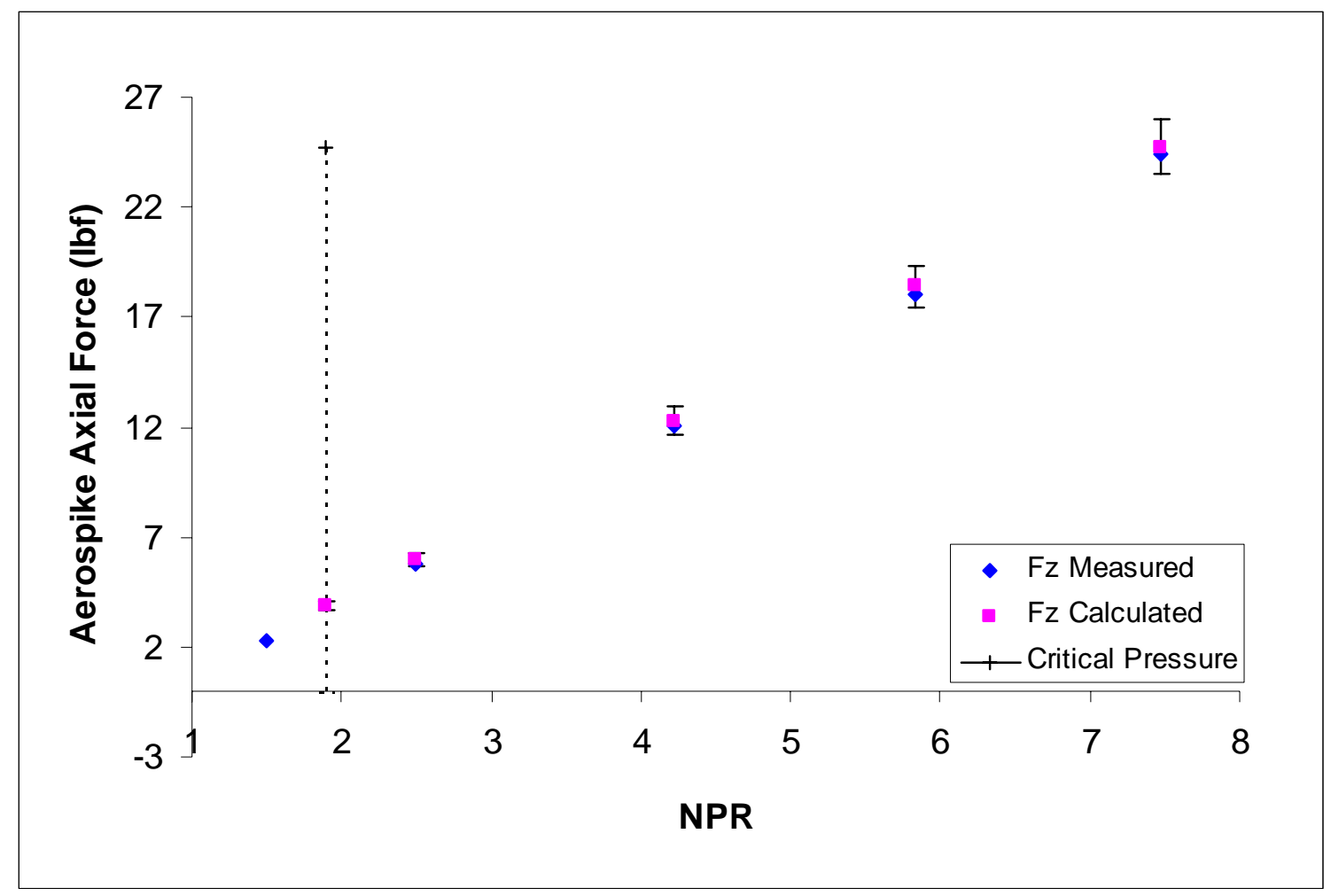

Figure 24. NPR50 Hole 3 Aerospike Nozzle Measured and Calculated Axial Force versus NPR. 
To observe the effect of chamber pressure on compound aerospike nozzle resultant turn angle, resultant turn angle $\left(\delta_{\text {calc }}\right)$ was calculated for each NPR value recorded during the experiment that varied chamber pressure. The calculated aerospike compound nozzle resultant turn angle $\left(\delta_{\text {calc }}\right)$ is graphed against NPR alongside the measured absolute values of resultant turn angle ( $\delta r)$ for aerospike compound nozzles: NPR6 Hole 3, NPR20 Hole 3, NPR20 Hole 5, NPR50 Hole 3 and shown as Figure 25, Figure 26, Figure 27, and Figure 28, respectively.

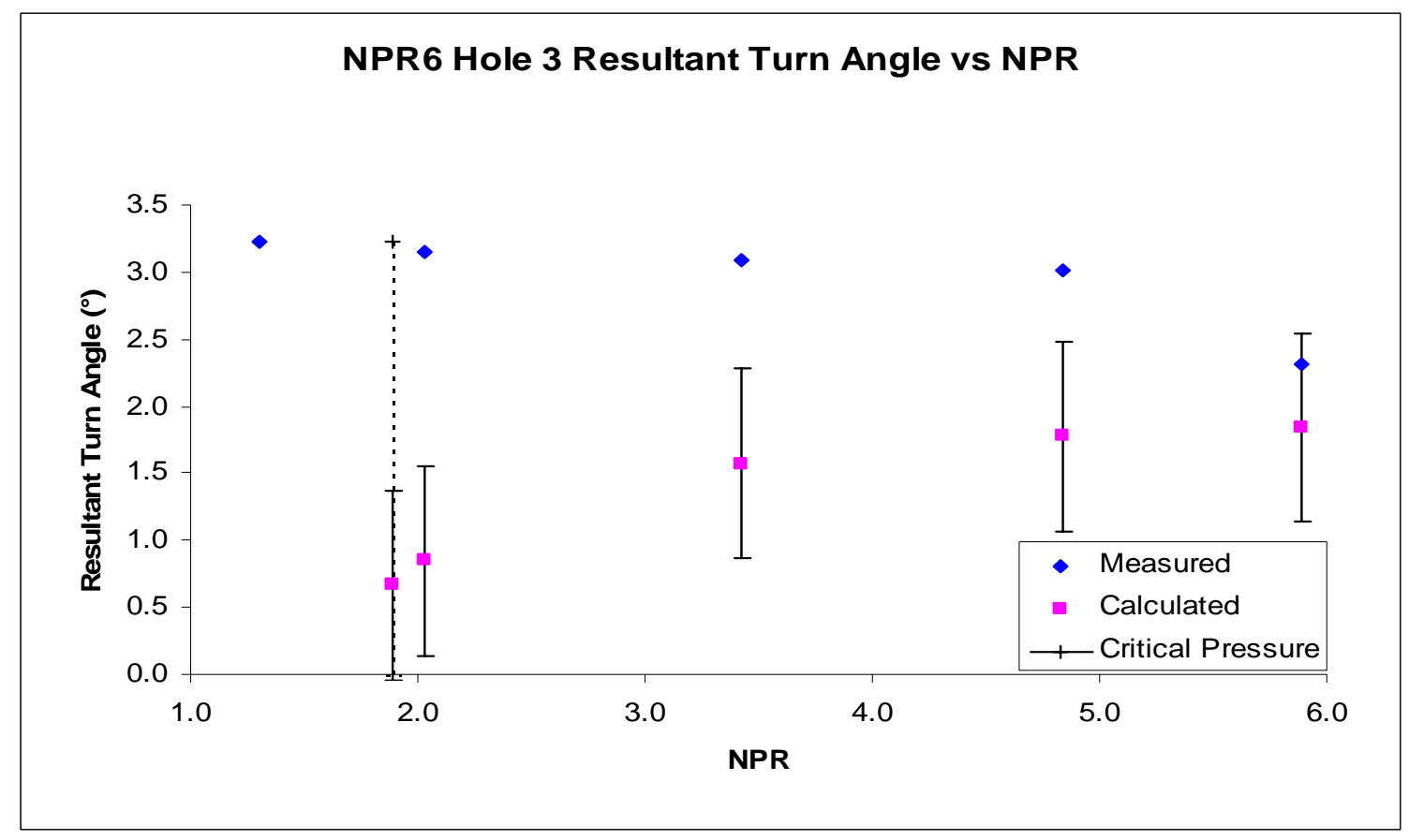

Figure 25. NPR6 Hole 3 Absolute Turn Angle versus NPR comparison of calculated and measured results. 


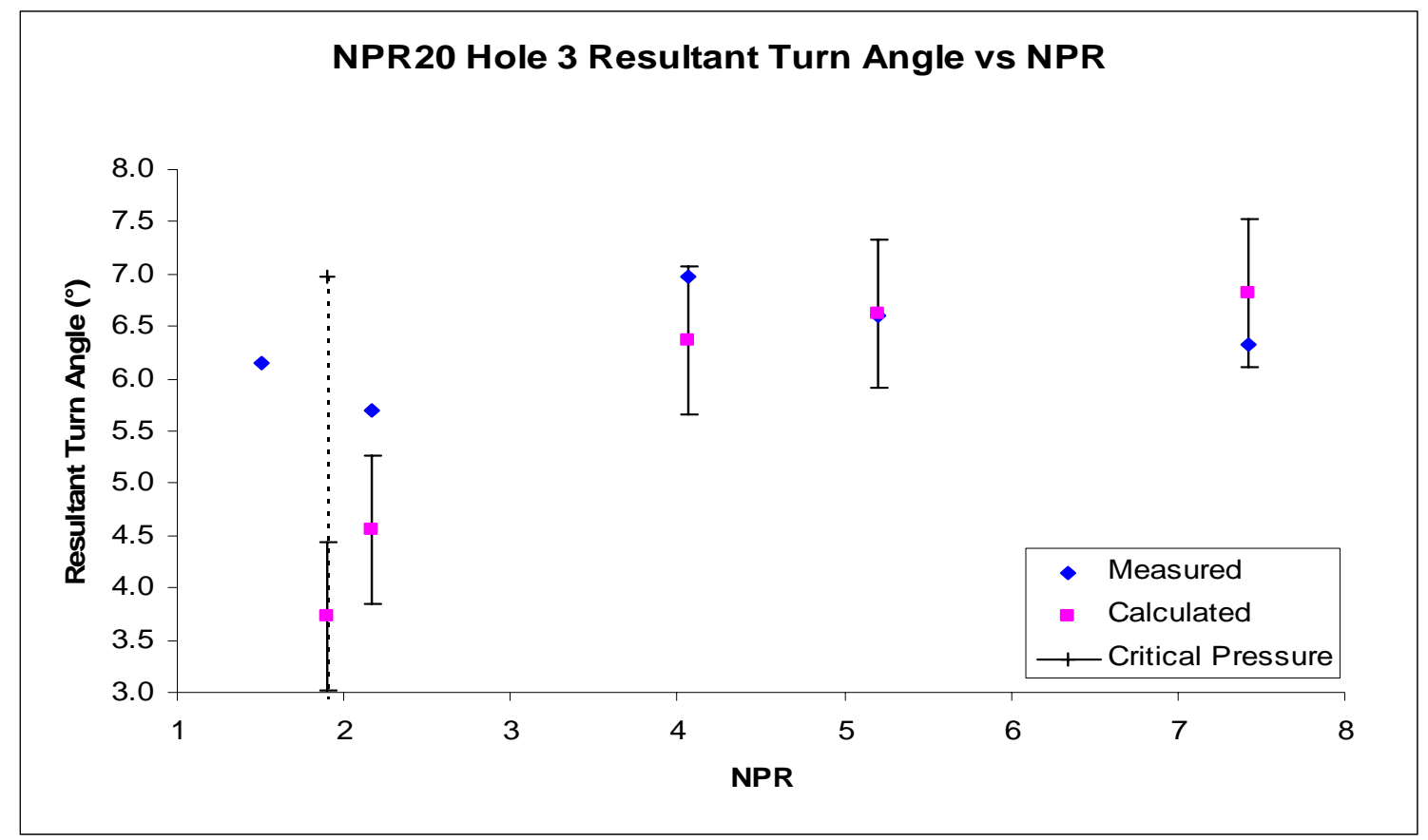

Figure 26. NPR20 Hole 3 Absolute Turn Angle versus NPR comparison of calculated and measured results.

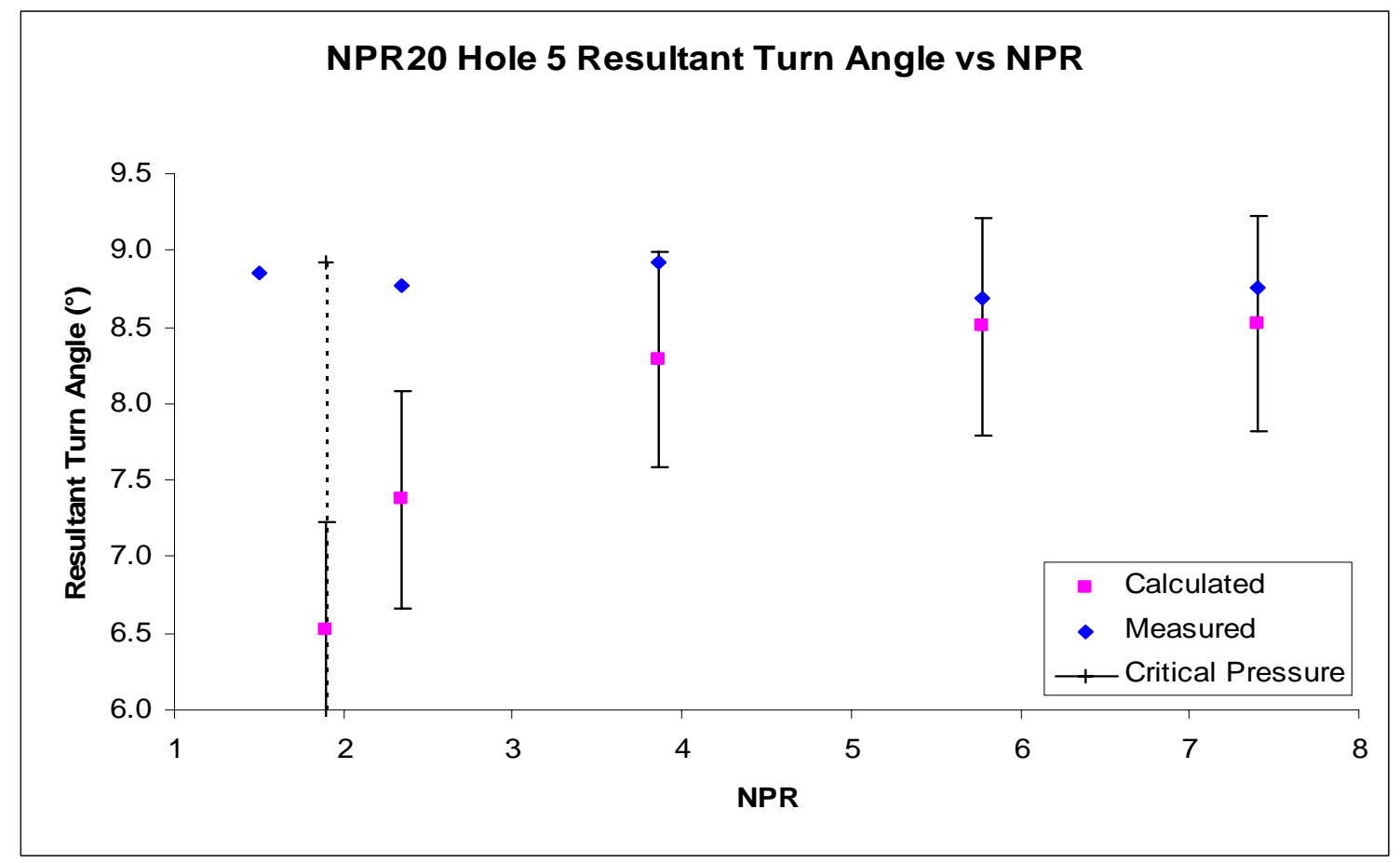

Figure 27. NPR20 Hole 5 Absolute Turn Angle versus NPR comparison of calculated and measured results. 


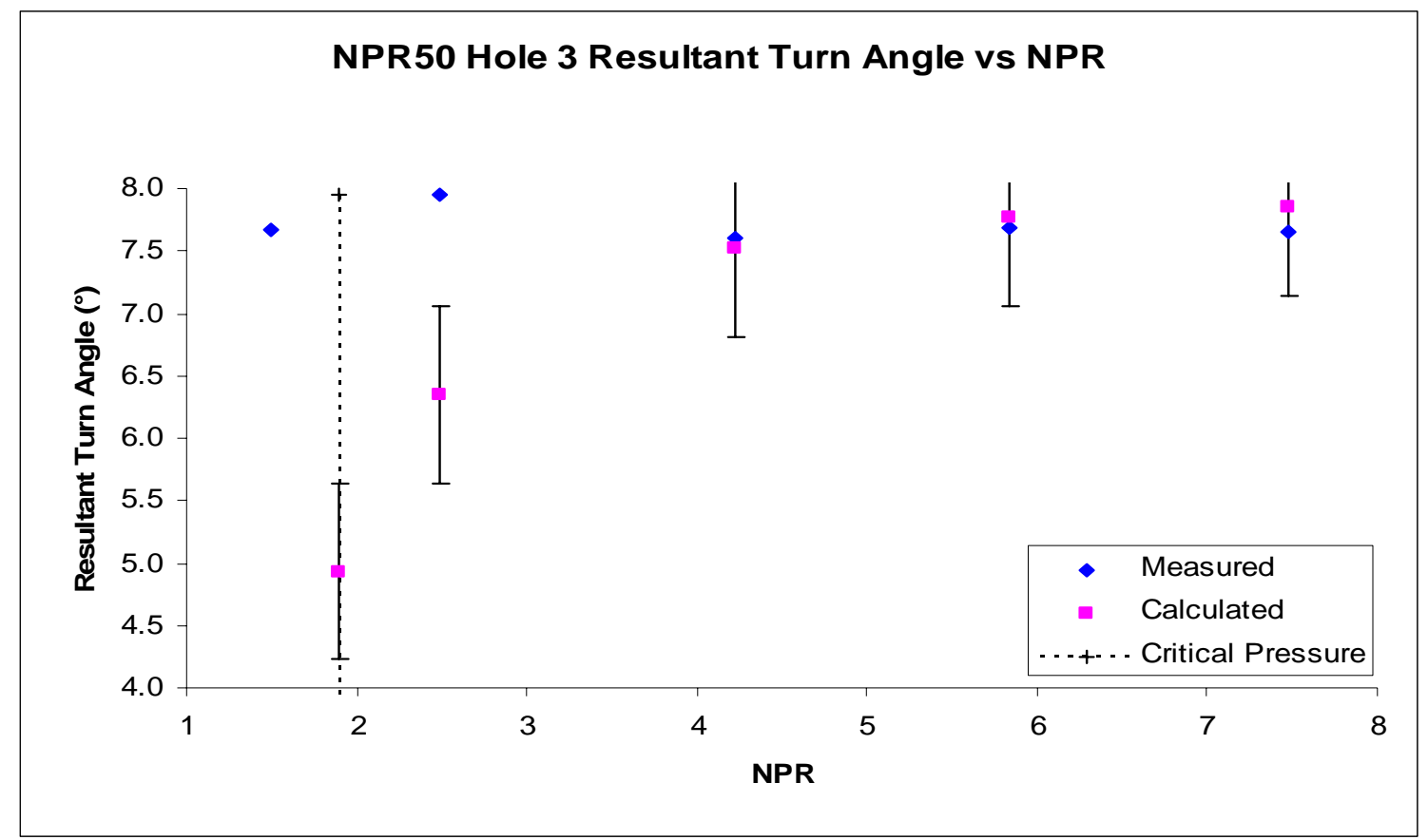

Figure 28. NPR50 Hole 3 Absolute Turn Angle versus NPR comparison of calculated and measured results.

For direct comparison, the calculated secondary port radial vectoring force $\left(F_{\text {calc }}\right)$ is translated into calculated resultant turn angle $\left(\delta_{\text {calc }}\right)$ by using the calculated aerospike axial force $\left(F_{z}\right.$ Calc $)$ and then compared to the measured aerospike axial force $\left(F_{z}\right)$, measured secondary port vectoring force $\left(F_{\text {vector }}\right)$ and measured resultant turn angle $\left(\delta_{r}\right)$. The results for these measured and calculated compound aerospike nozzle forces at each specific NPR value recorded during each test run are shown in Table 5. 
Table 5. Calculated and measured compound nozzle forces and turn angles.

\begin{tabular}{|c|c|c|c|c|c|c|c|c|c|c|}
\hline Run & Nozzle & $A_{e}$ & $A_{t}$ & $\mathrm{~T}_{1}$ & $\mathbf{P}_{1}$ & $F_{\text {calc }}$ & $F_{z \text { Calc }}$ & $F_{\text {vector }}$ & $\delta_{\mathrm{r}}$ & $\delta_{\text {calc }}$ \\
\hline & & $\mathrm{in}^{2}$ & $\mathrm{in}^{2}$ & ${ }^{\circ} \mathrm{F}$ & psi & $\mathrm{lbf}$ & lbf & lbf & $\circ$ & $\circ$ \\
\hline 2169 & NPR6 Hole 2 & 0.089 & 0.052 & 68.43 & 86.66 & 5.093 & -76.199 & 5.400 & 4.229 & 3.824 \\
\hline 2170 & NPR6 Hole 2 & 0.089 & 0.052 & 69.21 & 80.86 & 4.665 & -69.993 & 4.728 & 4.009 & 3.813 \\
\hline 2171 & NPR6 Hole 3 & 0.060 & 0.026 & 69.89 & 87.88 & 2.498 & -77.444 & 3.434 & 2.644 & 1.847 \\
\hline 2172 & NPR6 Hole 3 & 0.060 & 0.026 & 71.59 & 82.25 & 2.282 & -71.467 & 3.643 & 3.020 & 1.829 \\
\hline 2177 & NPR20 Hole 2 & 0.083 & 0.050 & 71.17 & 109.26 & 6.568 & -28.312 & 5.453 & 10.777 & 13.060 \\
\hline 2178 & NPR20 Hole 2 & 0.083 & 0.050 & 71.59 & 108.92 & 6.543 & -28.204 & 5.447 & 10.704 & 13.062 \\
\hline 2179 & NPR20 Hole 2 & 0.083 & 0.050 & 71.86 & 108.79 & 6.534 & -28.170 & 5.335 & 10.587 & 13.059 \\
\hline 2180 & NPR20 Hole 3 & 0.052 & 0.026 & 72.05 & 108.86 & 3.358 & -28.189 & 3.172 & 6.227 & 6.794 \\
\hline 2181 & NPR20 Hole 3 & 0.052 & 0.026 & 71.32 & 108.99 & 3.363 & -28.222 & 3.120 & 6.132 & 6.796 \\
\hline 2182 & NPR20 Hole 3 & 0.052 & 0.026 & 71.50 & 109.01 & 3.364 & -28.226 & 2.944 & 5.839 & 6.796 \\
\hline 2219 & NPR20 Hole 5 & 0.052 & 0.032 & 72.79 & 109.28 & 4.238 & -28.297 & 4.330 & 8.509 & 8.518 \\
\hline 2220 & NPR20 Hole 5 & 0.052 & 0.032 & 71.50 & 108.92 & 4.224 & -28.203 & 4.390 & 8.641 & 8.518 \\
\hline 2221 & NPR20 Hole 6 & 0.052 & 0.036 & 73.20 & 108.68 & 4.608 & -28.096 & 4.868 & 9.710 & 9.315 \\
\hline 2222 & NPR20 Hole 6 & 0.052 & 0.036 & 73.42 & 109.70 & 4.659 & -28.429 & 4.789 & 9.417 & 9.307 \\
\hline 2223 & NPR20 Hole 7 & 0.052 & 0.029 & 73.80 & 109.31 & 3.829 & -28.304 & 4.373 & 8.699 & 7.703 \\
\hline 2224 & NPR20 Hole 7 & 0.052 & 0.029 & 74.51 & 109.15 & 3.822 & -28.264 & 4.310 & 8.573 & 7.701 \\
\hline 2191 & NPR50 Hole 2 & 0.079 & 0.051 & 72.88 & 110.04 & 6.782 & -24.800 & 5.189 & 11.755 & 15.294 \\
\hline 2192 & NPR50 Hole 2 & 0.079 & 0.051 & 73.18 & 110.22 & 6.795 & -24.883 & 5.336 & 12.035 & 15.275 \\
\hline 2193 & NPR50 Hole 2 & 0.079 & 0.051 & 73.53 & 109.66 & 6.755 & -24.716 & 5.275 & 12.015 & 15.286 \\
\hline 2194 & NPR50 Hole 3 & 0.048 & 0.026 & 73.59 & 109.71 & 3.415 & -24.725 & 3.065 & 7.110 & 7.863 \\
\hline 2195 & NPR50 Hole 3 & 0.048 & 0.026 & 73.91 & 109.17 & 3.394 & -24.604 & 3.206 & 7.496 & 7.855 \\
\hline 2196 & NPR50 Hole 3 & 0.048 & 0.026 & 73.18 & 110.77 & 3.454 & -25.006 & 3.251 & 7.486 & 7.865 \\
\hline 2197 & NPR50 Hole 3 & 0.048 & 0.026 & 73.38 & 110.41 & 3.441 & -24.926 & 3.153 & 7.275 & 7.860 \\
\hline
\end{tabular}




\section{Results and Conclusions}

\section{Summary of Results}

Table 6 is a summary of results from the many experiments performed over the course of the research. Each row represents an average of all the data collected for that nozzle. The original data may be found in Appendix C. 
Table 6. Tabulated summary of results.

\begin{tabular}{|c|c|c|c|c|c|c|c|c|c|c|c|c|c|c|}
\hline $\begin{array}{c}\text { Nozzle } \\
\text { Description }\end{array}$ & NPR & $F_{x}$ & $F_{y}$ & $F_{z}$ & $\mathbf{W}_{\mathrm{p}}$ & $\mathbf{W}_{\mathrm{i}}$ & $F_{i}$ & $F_{r}$ & $F_{r} / F_{i}$ & $F_{z} / F_{i}$ & $\mathbf{W}_{\mathrm{p}} / \mathbf{W}_{\mathrm{i}}$ & $\delta_{\text {pitch }}$ & $\delta_{\text {yaw }}$ & $\delta_{\mathrm{r}}$ \\
\hline & & $\mathrm{Ib}_{\mathrm{f}}$ & $\mathrm{Ib}_{\mathrm{f}}$ & $\mathrm{Ib}_{\mathrm{f}}$ & $\mathrm{Ib}_{\mathrm{m}} / \mathrm{s}$ & $\mathrm{Ib}_{\mathrm{m}} / \mathrm{s}$ & $\mathrm{Ib}_{\mathrm{f}}$ & $\mathrm{Ib}_{\mathrm{f}}$ & & & & $\circ$ & $\circ$ & $\circ$ \\
\hline NPR6 Straight & 5.995 & -0.419 & -0.561 & -75.152 & 1.368 & 1.408 & 75.051 & 75.155 & 1.001 & -1.001 & 0.971 & 0.428 & 0.319 & -0.534 \\
\hline NPR6 Hole 1 & 3.614 & -3.935 & -0.206 & -68.098 & 1.443 & 0.939 & 62.719 & 68.213 & 1.089 & -1.087 & 1.543 & 0.177 & 3.317 & -3.323 \\
\hline NPR6 Hole 2 & 5.742 & -5.055 & -0.220 & -70.248 & 1.489 & 1.489 & 73.154 & 70.430 & 0.963 & -0.960 & 1.000 & 0.173 & 4.112 & -4.119 \\
\hline NPR6 Hole 3 & 5.851 & -3.337 & -0.215 & -72.115 & 1.519 & 1.532 & 74.347 & 72.193 & 0.971 & -0.970 & 0.991 & 0.170 & 2.656 & -2.662 \\
\hline $\begin{array}{l}\text { NPR20 Straight } \\
\text { Metal }\end{array}$ & 7.490 & -0.014 & -0.032 & -25.484 & 0.489 & 0.548 & 25.352 & 25.484 & 1.006 & -1.006 & 0.892 & 0.072 & 0.032 & -0.144 \\
\hline NPR20 Straight & 7.411 & -0.021 & -0.014 & -27.548 & 0.546 & 0.542 & 28.331 & 27.549 & 0.974 & -0.974 & 1.008 & 0.032 & 0.042 & -0.451 \\
\hline NPR20 Hole & 7.502 & -1.776 & -0.100 & -27.829 & 0.572 & 0.550 & 29.694 & 27.885 & 0.939 & -0.937 & 1.041 & 0.260 & 3.652 & -3.658 \\
\hline NPR20 Hole 2 & 7.472 & -5.411 & 0.079 & -28.669 & 0.649 & 0.544 & 33.681 & 29.175 & 0.866 & -0.851 & 1.193 & -0.158 & 10.687 & -10.689 \\
\hline NPR20 Hole 3 & 7.459 & -3.139 & 0.113 & -28.923 & 0.630 & 0.544 & 32.704 & 29.093 & 0.890 & -0.885 & 1.158 & -0.224 & 6.194 & -6.199 \\
\hline NPR20 Hole 5 & 7.448 & -4.358 & 0.280 & -28.757 & 0.640 & 0.545 & 33.192 & 29.087 & 0.877 & -0.867 & 1.174 & -0.558 & 8.618 & -8.636 \\
\hline NPR20 Hole 6 & 7.463 & -4.828 & 0.226 & -28.691 & 0.630 & 0.544 & 32.742 & 29.095 & 0.889 & -0.876 & 1.158 & -0.451 & 9.553 & -9.563 \\
\hline NPR20 Hole 7 & 7.465 & -4.336 & 0.211 & -28.586 & 0.652 & 0.544 & 33.946 & 28.914 & 0.852 & -0.842 & 1.200 & -0.424 & 8.626 & -8.636 \\
\hline $\begin{array}{l}\text { NPR20 Straight } \\
\text { Metal (Stan 1) }\end{array}$ & 7.453 & -0.098 & -0.032 & -29.831 & 0.582 & 0.546 & 30.126 & 29.832 & 0.991 & -0.991 & 1.066 & 0.062 & 0.188 & -0.200 \\
\hline $\begin{array}{l}\text { NPR20 Straight } \\
\text { Metal (Stan 2) }\end{array}$ & 7.460 & -0.053 & 0.050 & -32.488 & 0.608 & 0.546 & 31.512 & 32.488 & 1.032 & -1.032 & 1.114 & -0.088 & 0.092 & -0.164 \\
\hline $\begin{array}{l}\text { NPR20 Metal } \\
\text { Port (Stan 2) }\end{array}$ & 7.331 & -2.890 & 0.000 & -31.668 & 0.655 & 0.542 & 33.641 & 31.799 & 0.945 & -0.941 & 1.209 & 0.000 & 5.214 & -5.214 \\
\hline NPR50 STR4 & 7.600 & -0.029 & -0.038 & -23.266 & 0.475 & 0.483 & 24.840 & 23.268 & 0.937 & -0.937 & 0.985 & 0.091 & 0.069 & -0.614 \\
\hline $\begin{array}{l}\text { NPR50 Straight } \\
\text { Hole }\end{array}$ & 7.616 & -1.944 & 0.313 & -23.445 & 0.511 & 0.480 & 26.841 & 23.527 & 0.877 & -0.874 & 1.064 & -0.766 & 4.740 & -4.801 \\
\hline NPR50 Hole 2 & 7.539 & -5.266 & -0.045 & -24.915 & 0.591 & 0.476 & 30.765 & 25.466 & 0.828 & -0.810 & 1.239 & 0.102 & 11.934 & -11.935 \\
\hline NPR50 Hole 3 & 7.529 & -3.179 & 0.273 & -24.556 & 0.543 & 0.478 & 28.203 & 24.762 & 0.878 & -0.871 & 1.136 & -0.636 & 7.376 & -7.404 \\
\hline
\end{tabular}

NOTE: "NPR20 Straight Metal (Stan 2)" was modified by the addition of a hole to become "NPR20 Metal Port (Stan 2)". 


\section{Flow Behavior and Inlet Radius Results}

Axisymmetric, uniform flow from the secondary port has been

demonstrated. A radius on the secondary port inlet serves to minimize deflection of the secondary flow off of the radial axis of symmetry.

Schlieren photographs of many of the secondary ports show the secondary port flow angled slightly aft of the radial direction. With the addition of an inlet radius, it is immediately obvious from examining Schlieren photographs that the secondary port flow exhibits improved axial flow symmetry. The Schlieren photographs of radiused-inlet nozzles are shown in Figure 14.

The exact cause for the non-radial secondary port flow seen in the nozzles with sharp secondary port inlet edges is not known. It should be noted that all of the sharp inlet secondary port RP compound aerospike test nozzles exhibit some degree of non-radial, aft-deflection of the secondary port flow with larger secondary port throat diameters showing more deflection than the smaller secondary port throat diameters. However, the metal compound aerospike test nozzle "NPR20 Metal Port (Stan 2)" does not show any appreciable deflection of the secondary port flow off of the radial direction, despite the fact that the secondary port inlet is quite sharp.

There is the potential for a pressure gradient to exist across the secondary port inlet. Examination of the CAD models shows the largest NPR20 hole-type secondary port ("NPR20 Hole 2") to have the secondary port aft throat edge $0.061 \mathrm{in.} \mathrm{forward} \mathrm{of} \mathrm{the} \mathrm{aerospike} \mathrm{nozzle} \mathrm{throat} \mathrm{lip.} \mathrm{Recalling} \mathrm{the} \mathrm{pressure} \mathrm{tap}$ discussion and results shown in Figure 8, at the aft edge of the secondary port throat chamber air velocity is beginning to increase. Figure 29 shows the 40 
location of the secondary port throat edges of NPR20 Hole 2 relative to the pressure tap data.

Static pressure readings in the chamber of 90 psig equates to a velocity of approximately Mach 0.43 based on the stagnation pressure reading of approximately 104 psig taken immediately forward of the compound aerospike nozzle attachment on the thrust stand. The location of the stagnation pressure tap can be seen on the right in Figure 7. The highest pressure from stagnation of any flow entering the secondary port is 104 psig for a difference of 14 psi relative to the 90 psig static chamber pressure reading. Whether or not 14 psi of stagnation pressure gradient within the secondary port is sufficient to redirect the secondary port flow off of the radial axis (as evidenced in the Schlieren photographs in Figure $\mathbf{1 0}$ through Figure 12) has not been evaluated and is beyond the scope of this work.

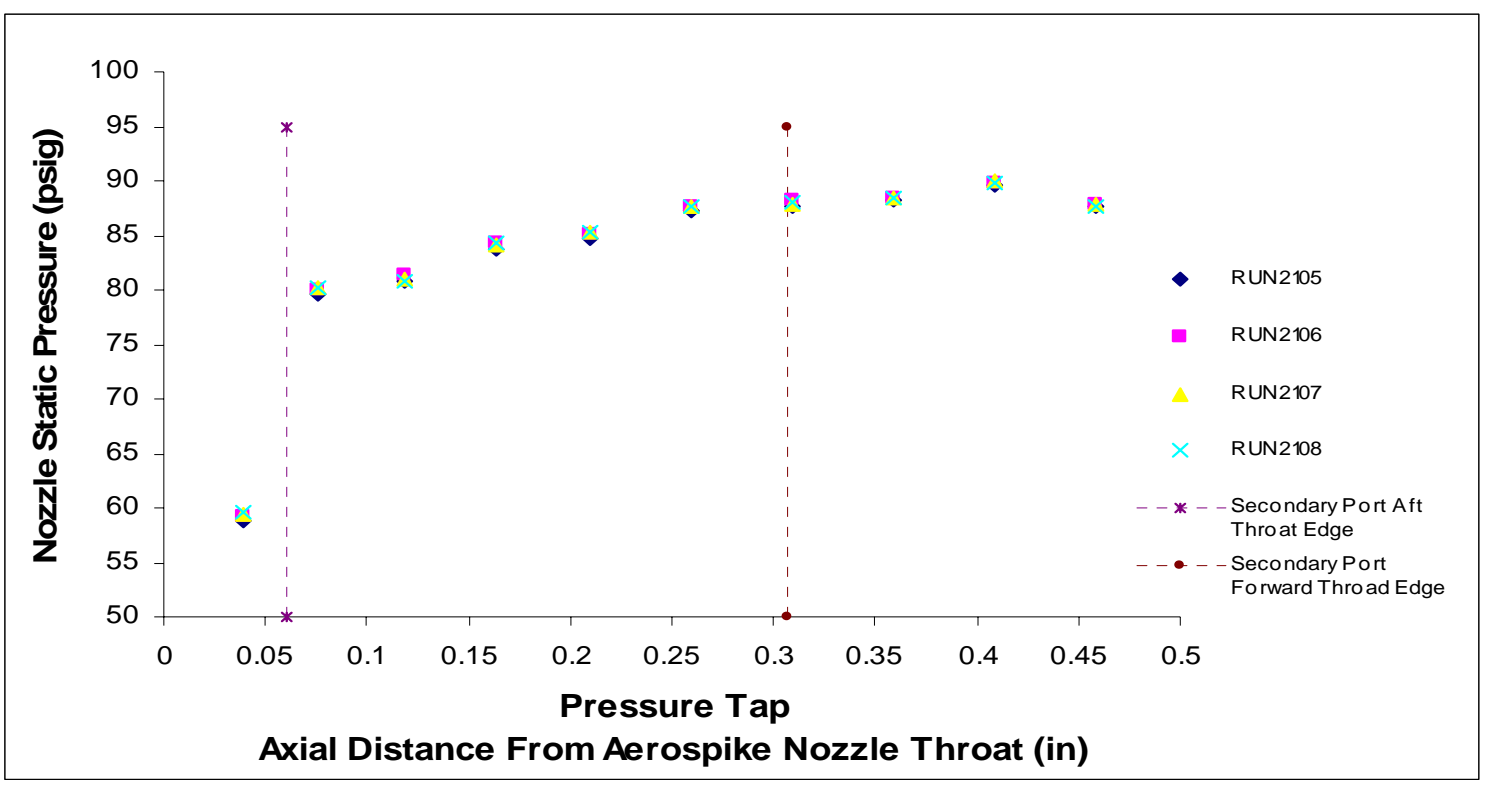

Figure 29. NPR20 Hole 2 pressure distribution at inlet of secondary port. Dashed lines show location of secondary port throat aft and forward edges. Note the possibility of a pressure gradient across the secondary port throat. 


\section{Metal Nozzles Results}

Special attention should be paid to the shock patterns of the Schlieren photographs in Figure 30 of "NPR20 Straight Metal (Stan 1)" and "NPR20 Metal Port (Stan 2)". It appears that "NPR20 Metal Port (Stan 2)" has incurred additional disturbances with a greater number of shock waves visible midway aft on the aerospike. It also appears that the aerospike nozzle flow is no longer radially symmetrical. It is unknown whether these disturbances are the result of the sharp secondary port entrance or from the radially asymmetrical flow of air through the aerospike nozzle throat, as air was diverted out of the secondary port. The Schlieren images of NPR20 Straight Metal (Stan 1) and NPR20 Metal Port (Stan 2) are shown again in larger format in Figure $\mathbf{3 0}$ to show details and are identical to Schlieren photographs shown in Figure 13. 


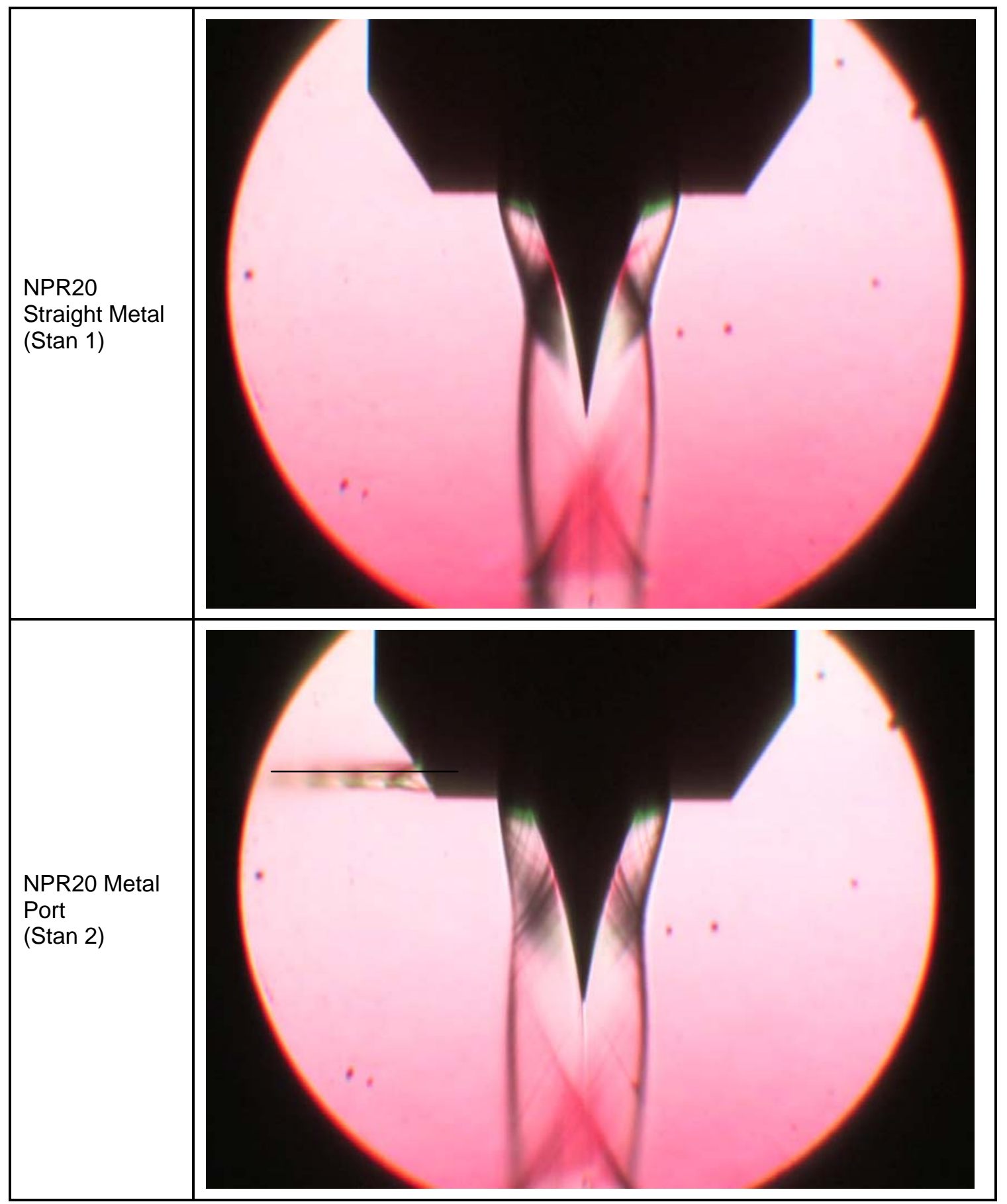

Figure 30. Schlieren photographs of two NPR20 metal nozzles. The two are of the same design and construction with the exception of the hole-type secondary port on "NPR20 Metal Port (Stan 2)". Note the additional aerospike nozzle flow perturbations on NPR20 Metal Port (Stan 2). 


\section{Chamber Pressure and Turn Angle Results}

Effective turn angle capability of the hole-type compound nozzle has been demonstrated in both NPR20 and NPR50 nozzles that produced up to $10.7^{\circ}$ and $11.9^{\circ}$ of turn, respectively. Sufficient inlet radius to provide radial flow is also necessary for good performance predictability.

Test results shown in Figure $\mathbf{1 5}$ indicate that measured turn angle is largely independent of chamber pressure. When compared to calculated turn angle results, the observed linear behavior of turn angle to changing chamber pressure is contrary to what is expected as the thrust produced by both the aerospike nozzle and the secondary port vary linearly with chamber pressure and show good correlation to calculated results. However, nozzle "NPR20 Hole 3" does exhibit a small degree of predicted drop in turn angle as chamber pressure was reduced.

Examination of the graphs of calculated versus measured aerospike nozzle axial force and secondary port radial force shown in Figure $\mathbf{1 7}$ through Figure $\mathbf{2 4}$ show excellent linearity and correlation between measured and calculated results except for NPR 6 Hole 3 secondary port radial force shown in Figure 17, which shows large differences in measured and calculated results.

The excellent correlation between measured and calculated results for aerospike nozzle axial force shown in Figure $\mathbf{2 1}$ through Figure $\mathbf{2 4}$ indicates that the secondary port has no measurable effect on aerospike nozzle performance.

It is suspected that geometrical error resulting from the rapid prototyping process is a significant contributor to poor correlation between measured and calculated results. Thin features and sharp edges are often poorly replicated 
during the RP process. The secondary port inlet area in particular is formed by a sharp edge in all but those nozzles with inlet radii. Actual measurement of the secondary port throat diameter to verify the dimension proved impossible.

Compound aerospike nozzles with secondary port inlet radii show good results in terms of predictability as well as flow symmetry. Comparisons between calculated and measured compound aerospike nozzle resultant turn angles on a run-by-run basis are shown in Table $\mathbf{5}$ are shown graphically as Figure 31 through Figure 33. Excellent correlation between measured and calculated data can be found in the nozzles with inlet radii (NPR20 Hole 5, 6, and 7) in Figure 32. The good correlation observed in nozzles equipped with secondary port inlet radii further reinforces the importance of a smooth inlet region for performance predictability and flow symmetry as also seen in the Schlieren photographs.

Interestingly, the nozzle with the best predictability (NPR20 Hole 5) is designed with the mid-sized secondary port inlet radii (0.050 in.). Without higher resolution nozzles and a test array of inlet radii models, it is uncertain if there is indeed an ideal relationship between secondary port throat size and inlet radius. 


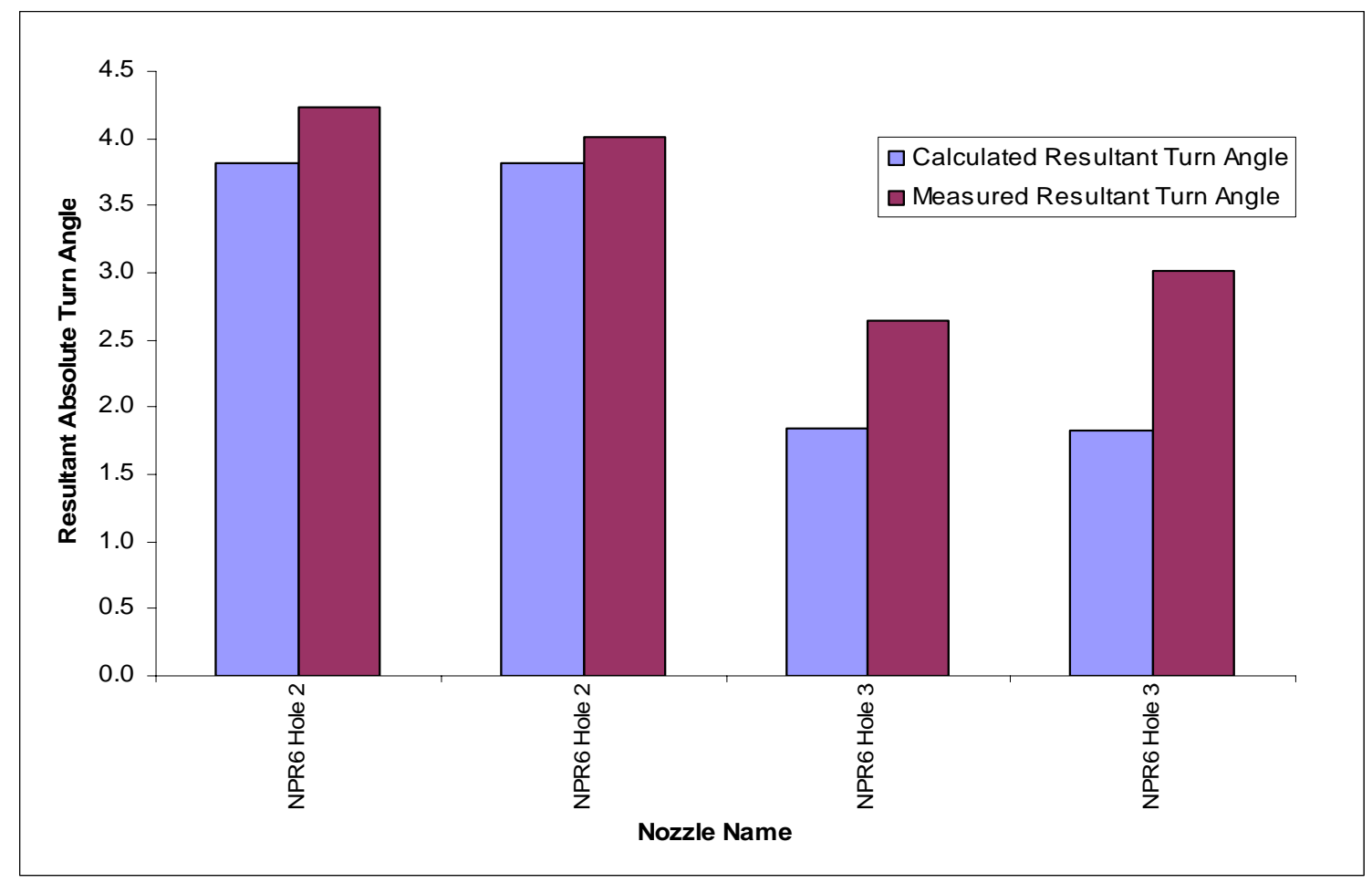

Figure 31. Comparison between calculated and measured turn angles for NPR6 nozzles on a run-by-run level.

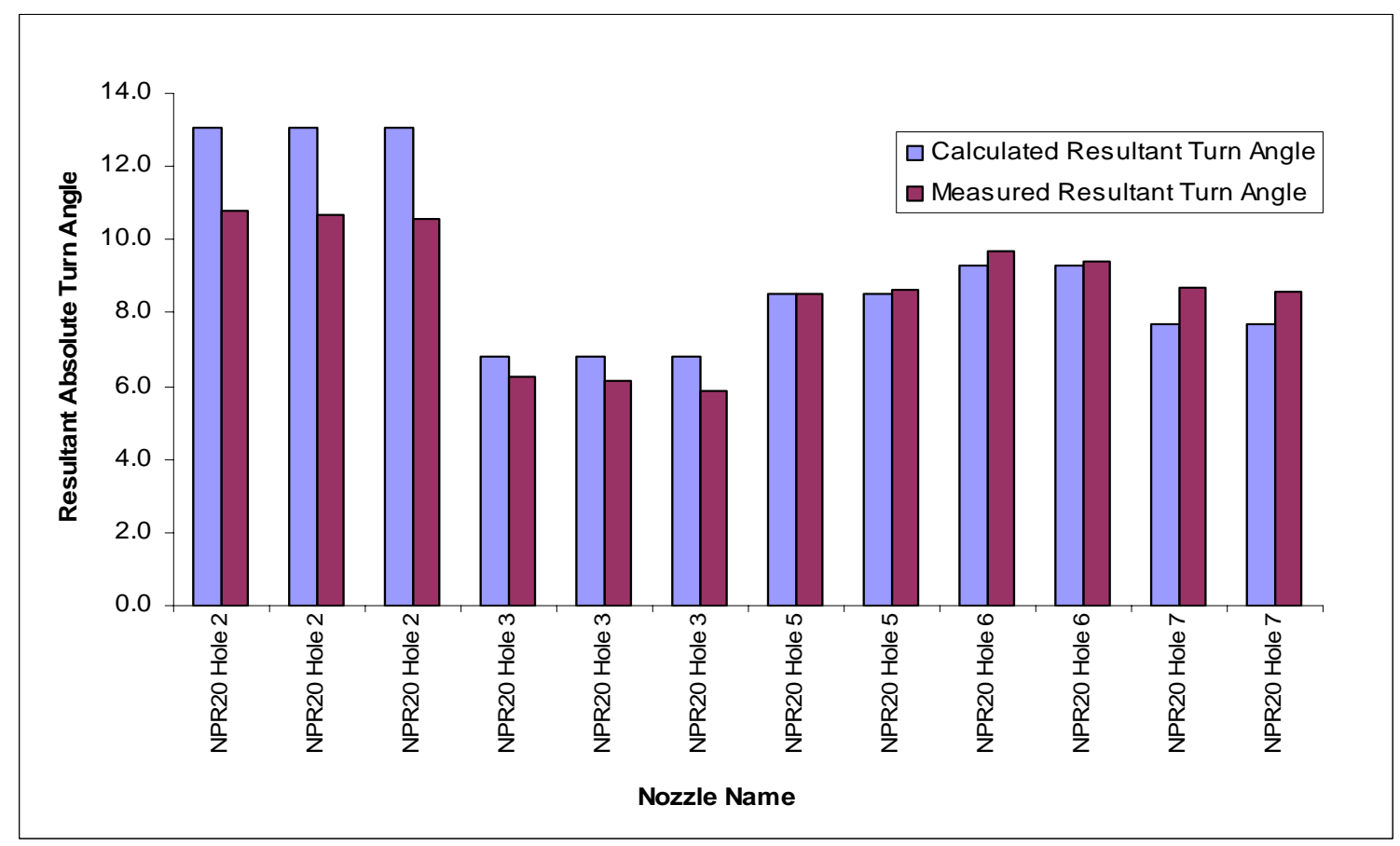

Figure 32. Comparison between calculated and measured turn angles for NPR20 nozzles on a run-by-run level. 


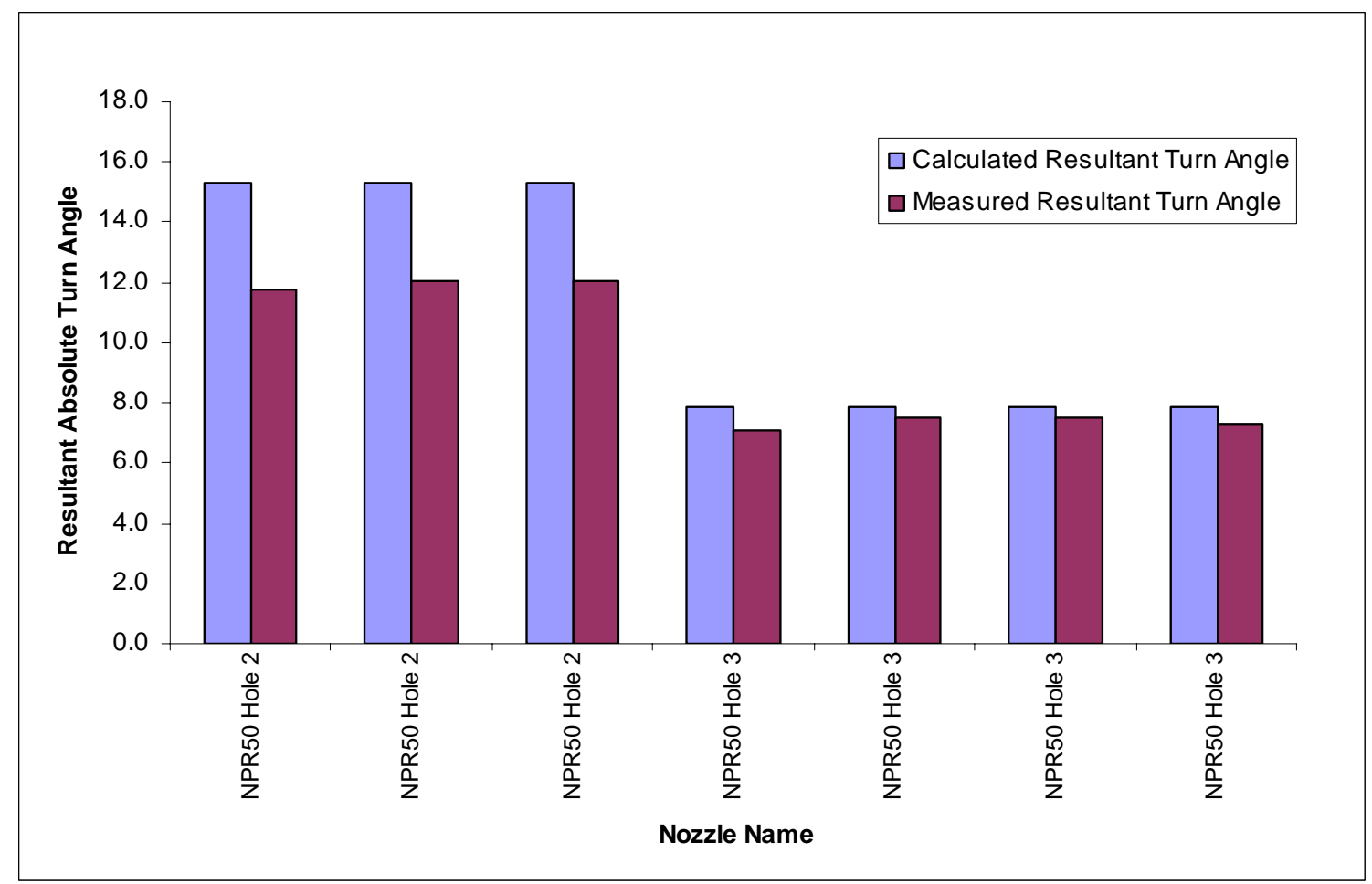

Figure 33. Comparison between calculated and measured turn angles for NPR50 nozzles on a run-by-run level. 


\section{Conclusions}

A hole-type compound aerospike nozzle was found to provide effective thrust vectoring. The addition of a secondary port did not affect aerospike nozzle axial force. The addition of an inlet radius on the secondary port provided significant improvements in the development of axisymmetric flow. Compound aerospike nozzle axial force and radial vectoring forces showed excellent correlation between measured and calculated results.

The cause of non-axisymmetric secondary port flow observed in Schlieren photographs is not known. Possible causes include the presence of a pressure gradient across the secondary port throat, flow attachment to the diverging section of the secondary port, and turning of flow through shock waves at the secondary port throat.

The poor resolution of the RP nozzle models leaves significant uncertainties in the geometry of the models at this scale. While the nozzles presented in this thesis may be sufficient for qualitative assessment, larger models or higher resolution during the RP process would be necessary for further development. 


\section{Bibliography}

Carpenter, T.W., and Gerhardt, J.A. "Nozzle Flow Thrust Vector Measurement." U.S. Patent 6032 545, 1998.

Erickson, C., "Thrust Vector Control Selection in Aerospike Engines," Proceedings of the $33^{\text {rd }}$ AIAA/ASME/SAE/ASEE Joint Propulsion Conference \& Exhibit, AIAA, Seattle, WA, 1997, AIAA Paper 1997-3307.

Greer, H., "Rapid Method for Plug Nozzle Design," ARJ Journal, Nov. 1960, pp. 560-561.

Hall, P.E., "Validation and Performance Evaluation of a Dual Flow Thrust Stand," Master's Thesis, California Polytechnic State University, 1994.

Lee, C.C., and Thompson, D.D., "Fortran Program for Plug Nozzle Design," NASA TM X-53019, 1964.

NASA Dryden Flight Research Center (2004), "Aerospike Engine Flight Test Successful," [Online]. Available at http://www.nasa.gov/centers/dryden/news/NewsReleases/2004/04-23.html (accessed 26 January 2009). Posted News Release. 
Nasuti, F., and Onofri, M., "Analysis of In-Flight Behavior of Truncated Plug Nozzles" Proceedings of the $33^{\text {rd }}$ AIAA/ASME/SAE/ASEE Joint Propulsion Conference \& Exhibit, AIAA, Seattle, WA, 1997, AIAA Paper 2000-3289.

Rao, G.V.R., "Spike Nozzle Contour for Optimum Thrust" Proceedings of the Fourth AFBMD/STL Symposium on Advances in Ballistic Missile and Space Technology, vol. 1, Permagon Press, New York, 1961, pp. 92-101.

Rohlik, N., "Thrust vector optimization of 10 degree gimbaled finned aerospike nozzles," Master's Thesis, California Polytechnic State University, 2008.

Rossi, R. A., "Undeflected Dual Flow Thrust Vectoring Nozzle Performance," Master's Thesis, California Polytechnic State University, 1994.

Ruf, J.H., and McMonnaughey, P.K., "The Plume Physics Behind Aerospike Nozzle Altitude Compensation and Slipstream Effect," Proceedings of the $33^{\text {rd }}$ AIAA/ASME/SAE/ASEE Joint Propulsion Conference \& Exhibit, AIAA, Seattle, WA, 1997, AIAA Paper 97-3218.

Sutton, G. P., "History of Liquid Propellant Rocket Engines," AIAA, Reston, VA, Nov. 2005, pp. 94-96. 


\section{Appendix A: Equations}

Thrust: $F_{\text {vector }}=\dot{m} V_{e}+\left(p_{e}-p_{o}\right) A_{e}$

Exit Velocity: $V_{e}=M_{e} \sqrt{k R T_{e}}$

Mass Flow Rate: $\dot{m}=A_{t} p_{1} \frac{k \sqrt{\left[\frac{2}{k+1}\right]^{\frac{k+1}{k-1}}}}{\sqrt{k R T_{1}}}$

Resultant Turn Angle: $\delta_{r}=\tan ^{-1}\left(\frac{F_{\text {vector }}}{F_{z}}\right)$ 


\section{Appendix B: Nozzle Geometry}

The technical drawings shown in Figure $\mathbf{3 4}$ through Figure $\mathbf{4 8}$ reveal the specific geometry of each nozzle as it was introduced to the RP machine and represents all nozzles discussed in the text. 

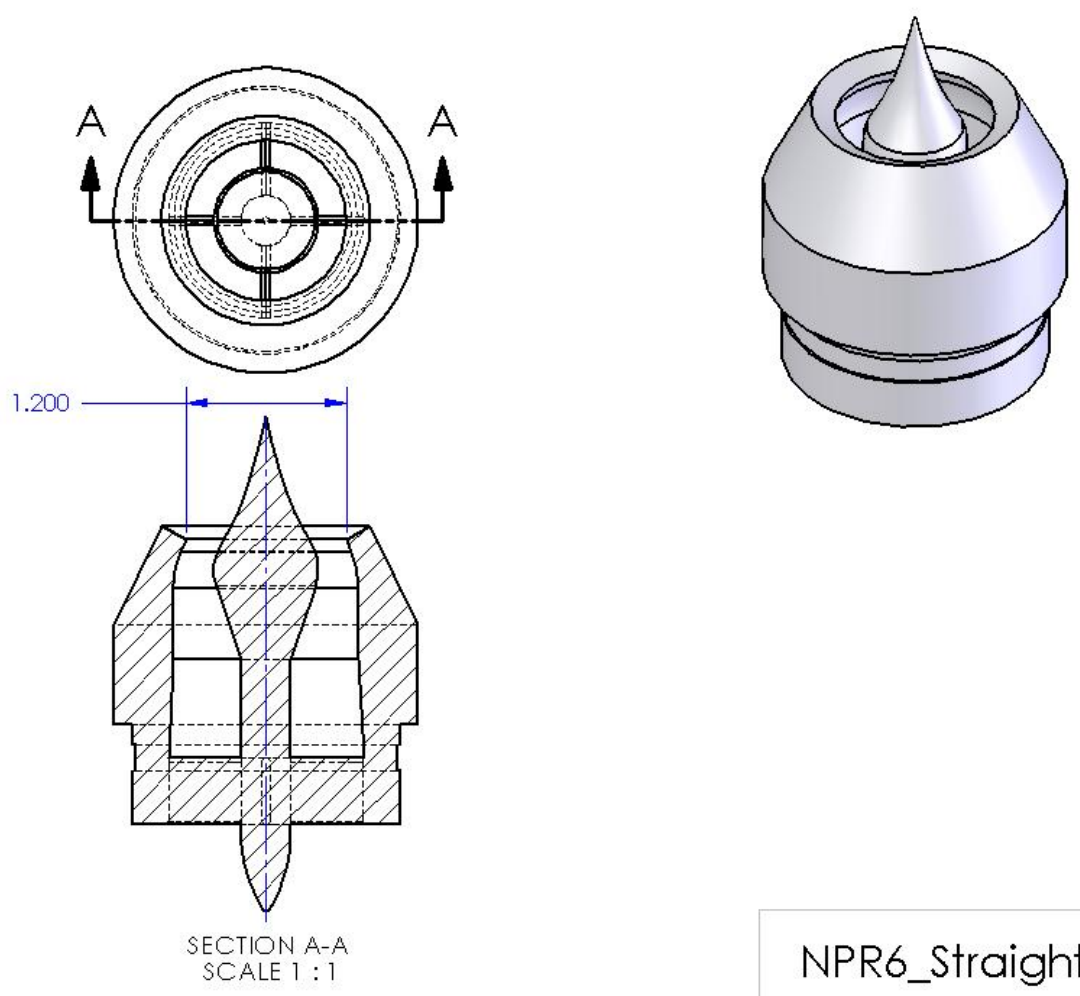

NPR6_Straight

Figure 34. NPR6 Straight design drawing. 

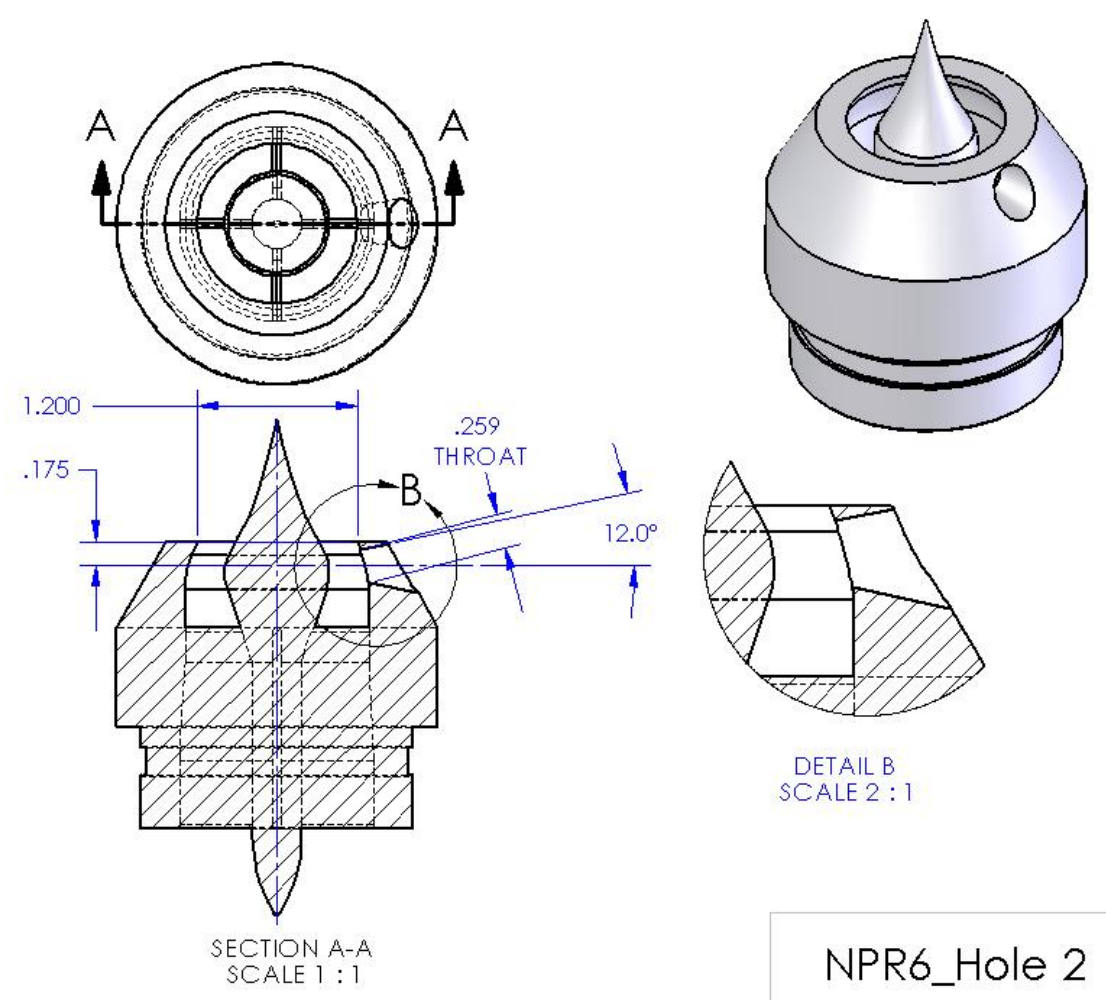

DETAIL B

SCALE $2: 1$

NPR6_Hole 2

Figure 35. NPR6 Hole 2 design drawing. 

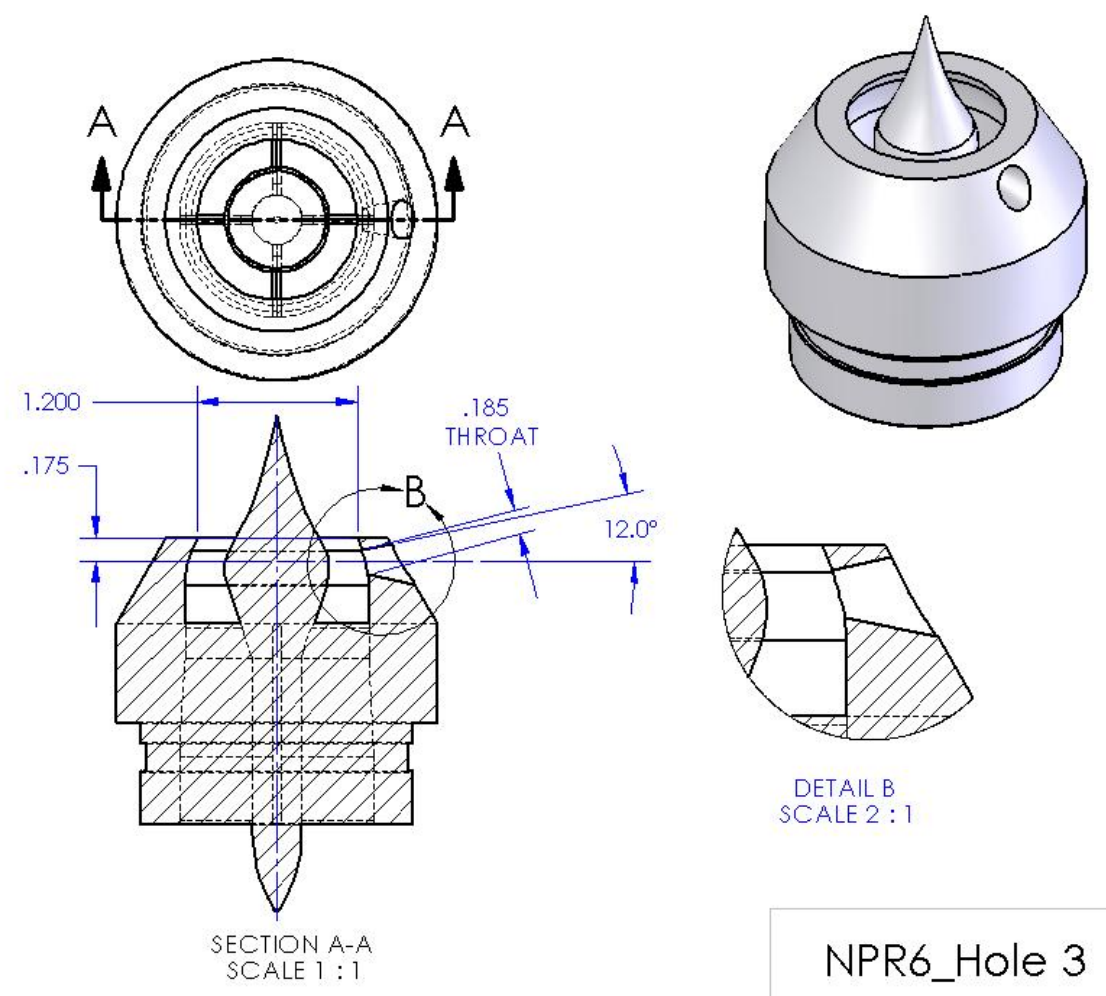

NPR6_Hole 3

Figure 36. NPR6 Hole 3 design drawing. 


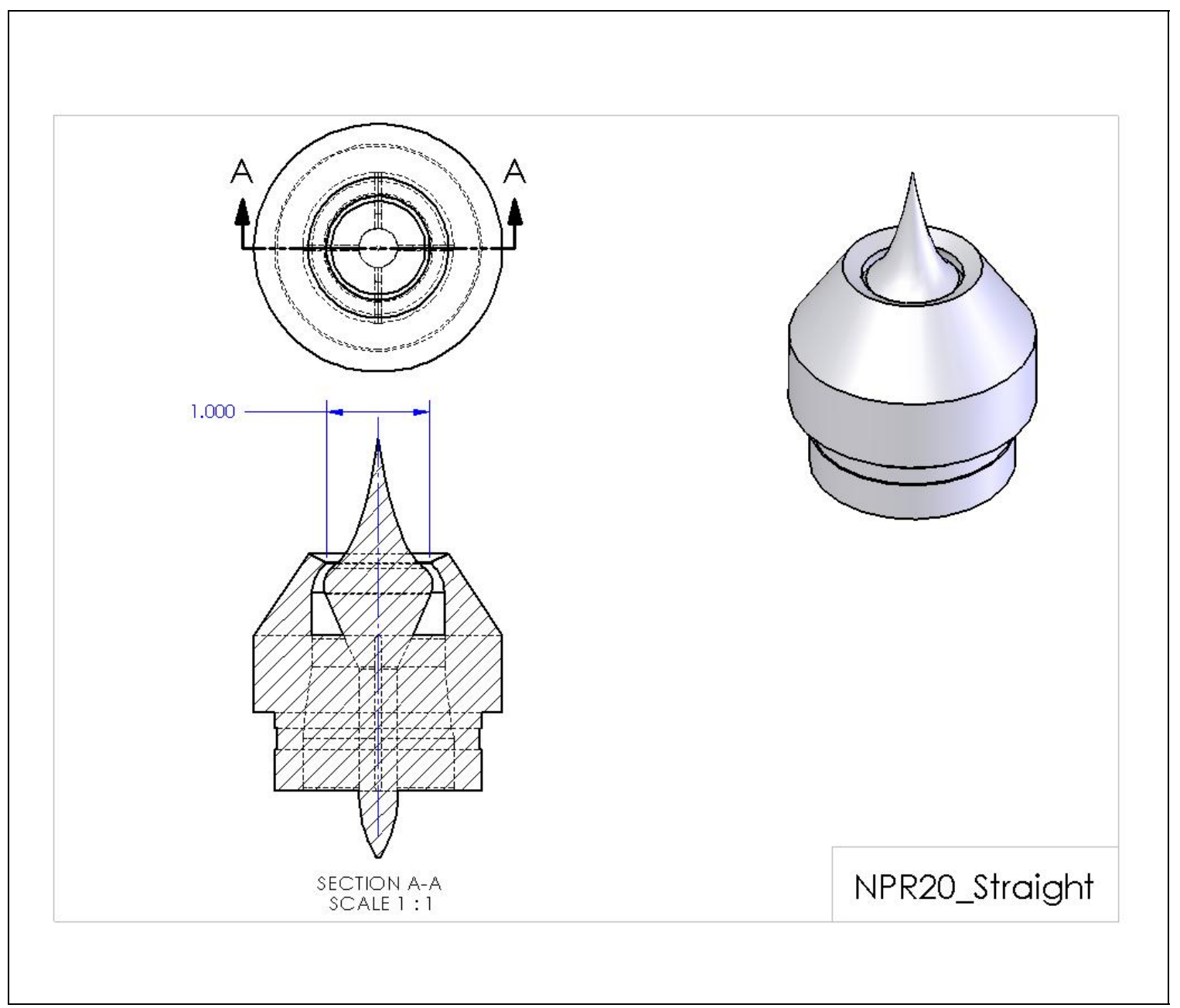

Figure 37. NPR20 Straight design drawing. 


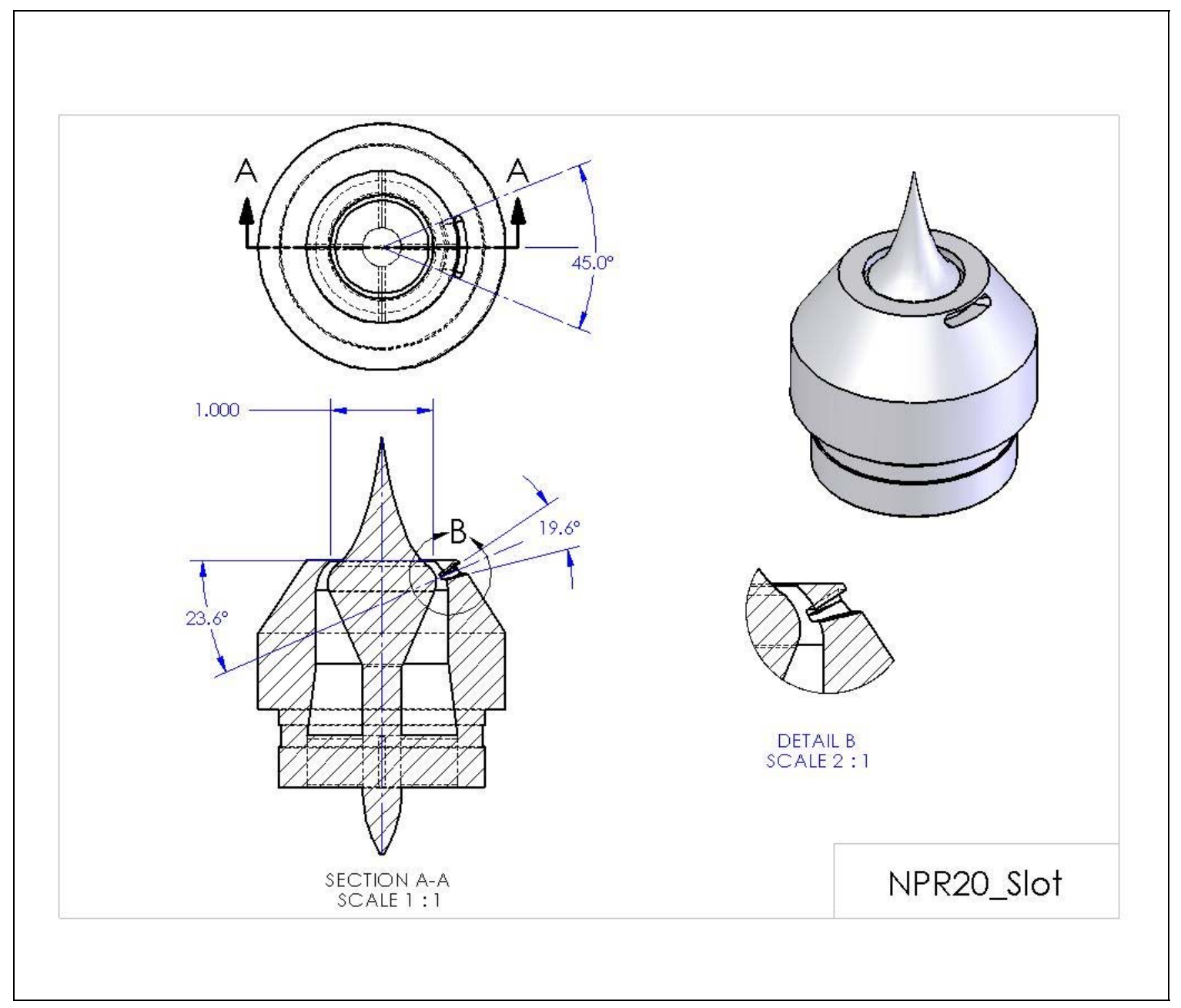

Figure 38. NPR20 Slot design drawing. 


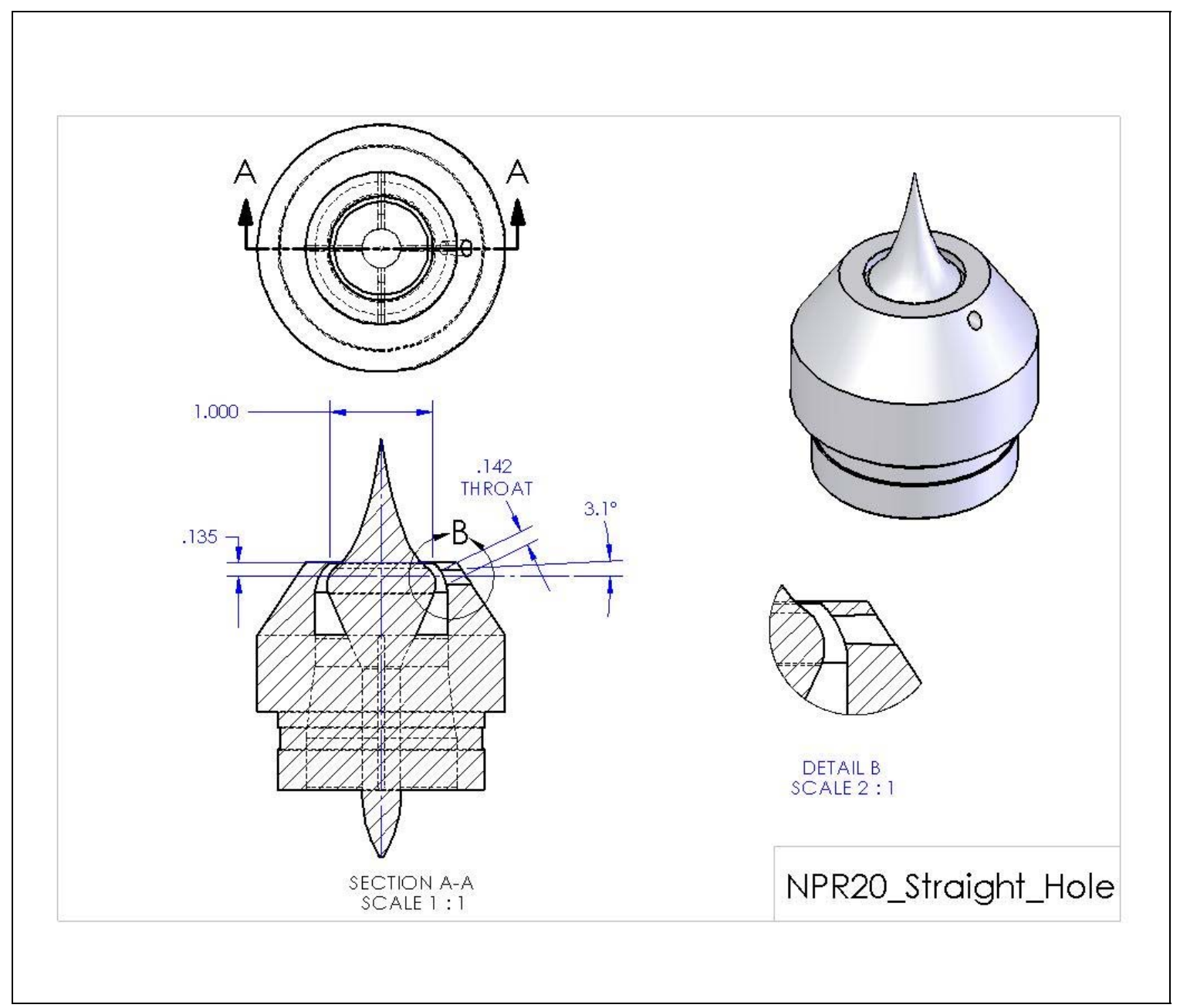

Figure 39. NPR20 Straight Hole design drawing. 


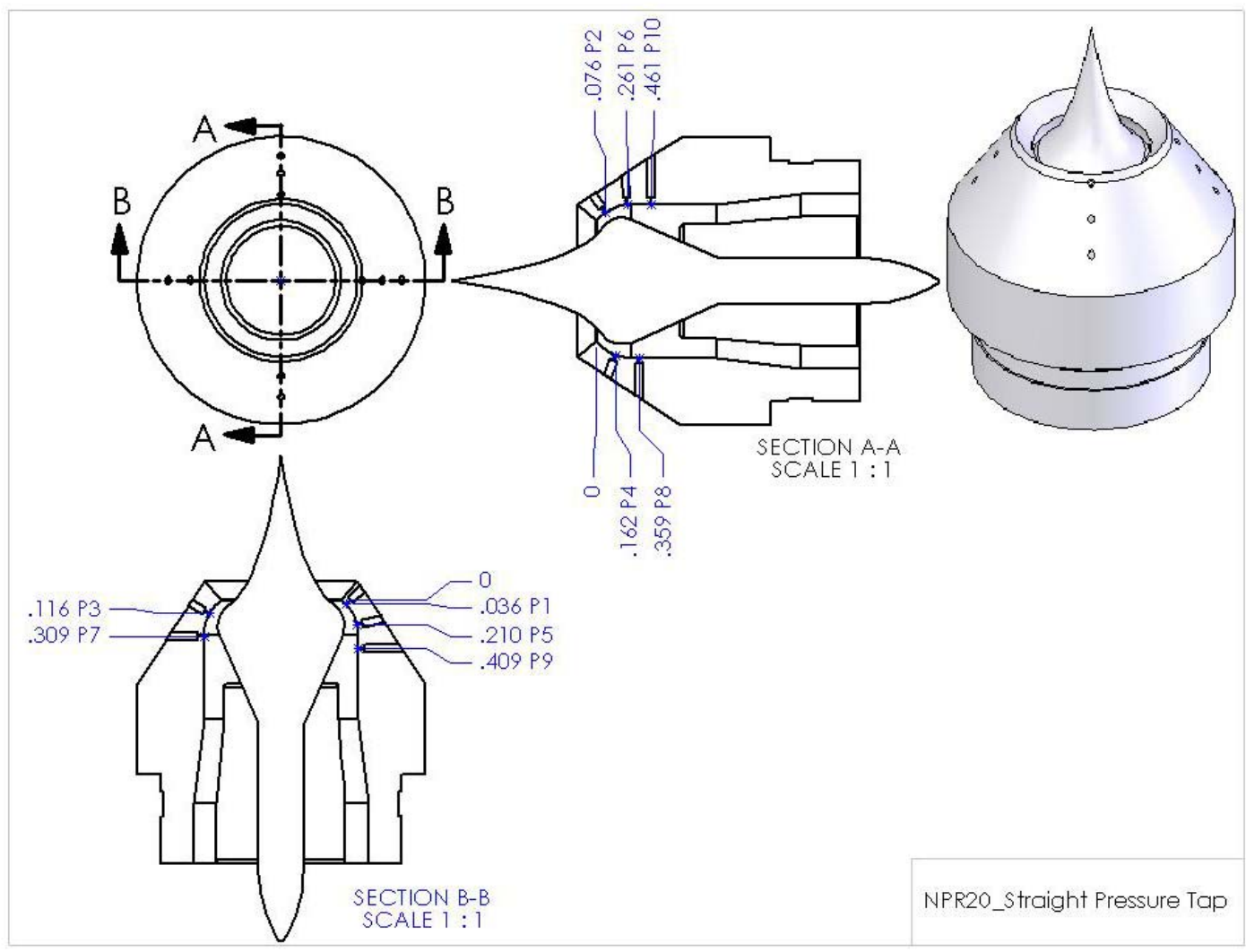

Figure 40. NPR20 Straight Pressure Tap design drawing. 


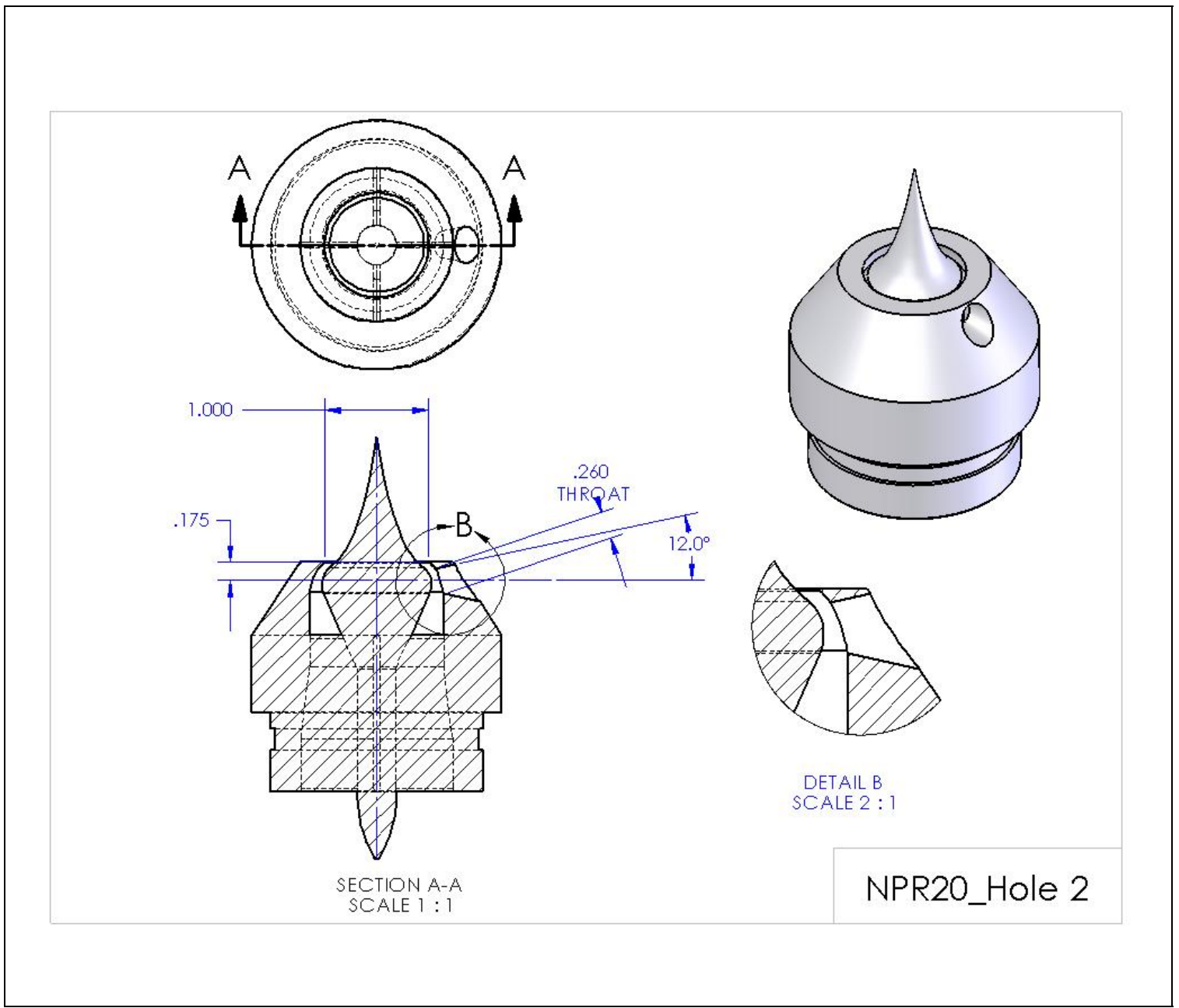

Figure 41. NPR20 Hole 2 design drawing. 


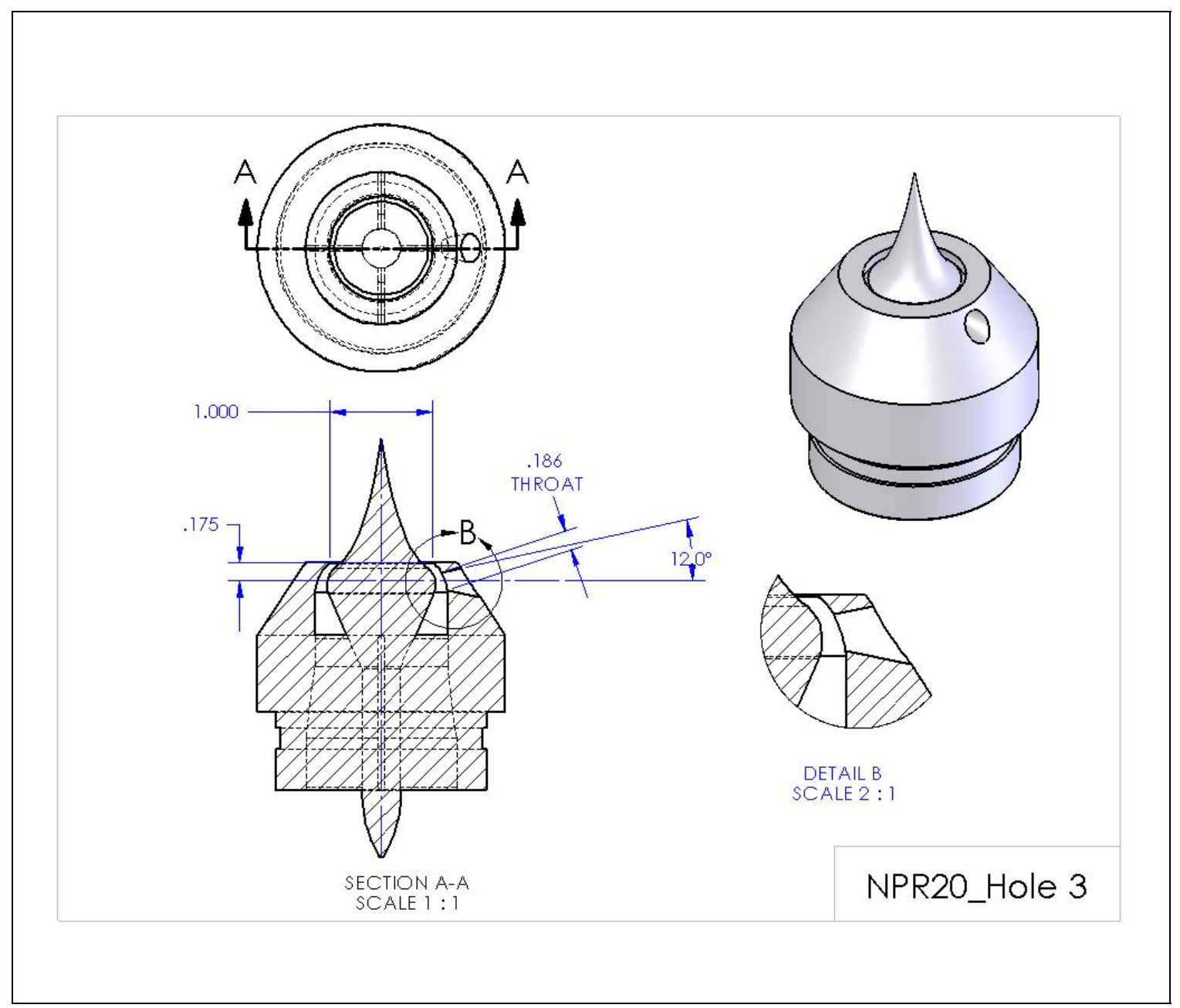

Figure 42. NPR20 Hole 3 design drawing. 


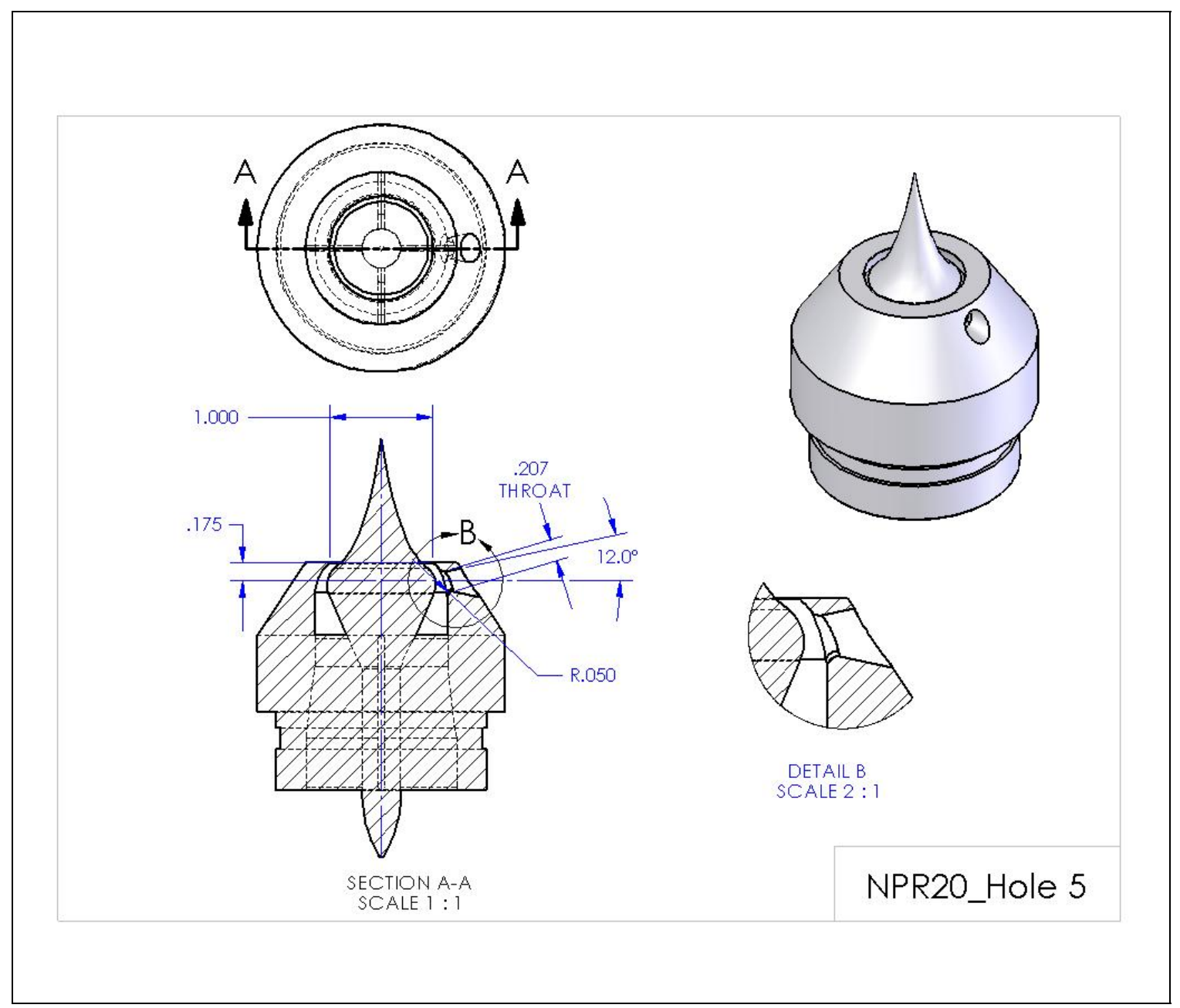

Figure 43. NPR20 Hole 5 design drawing. 


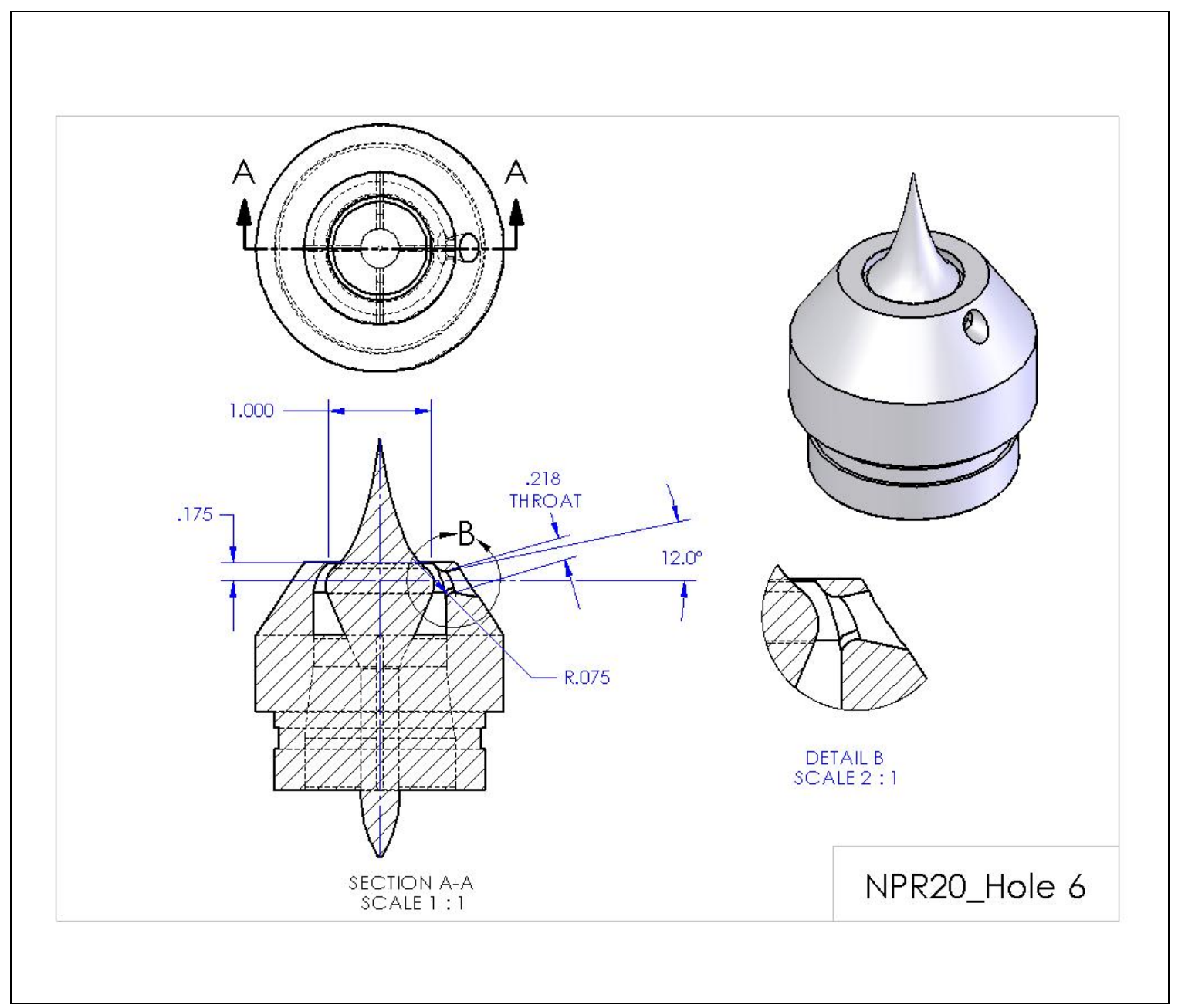

Figure 44. NPR20 Hole 6 design drawing. 


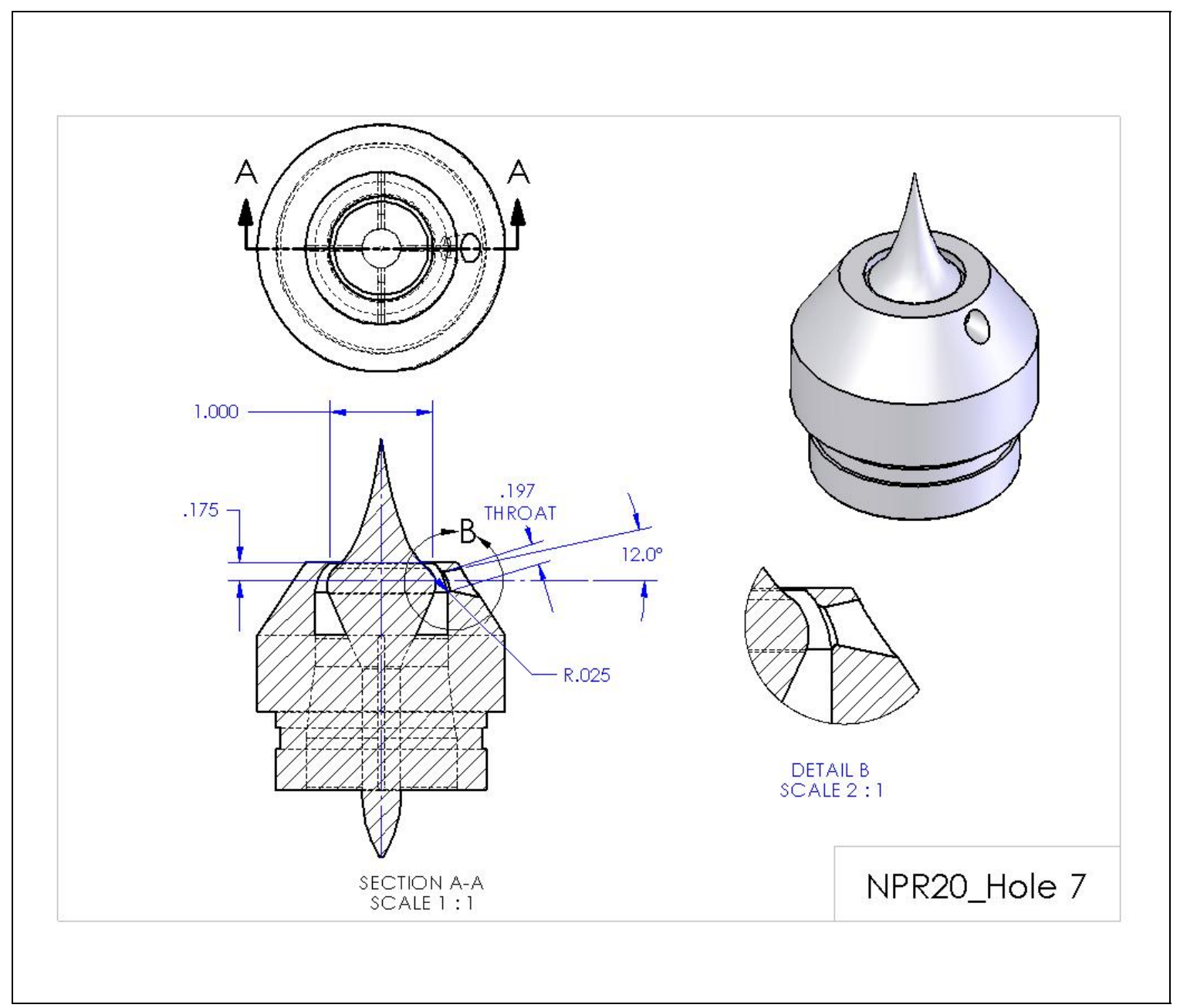

Figure 45. NPR20 Hole 7 design drawing. 


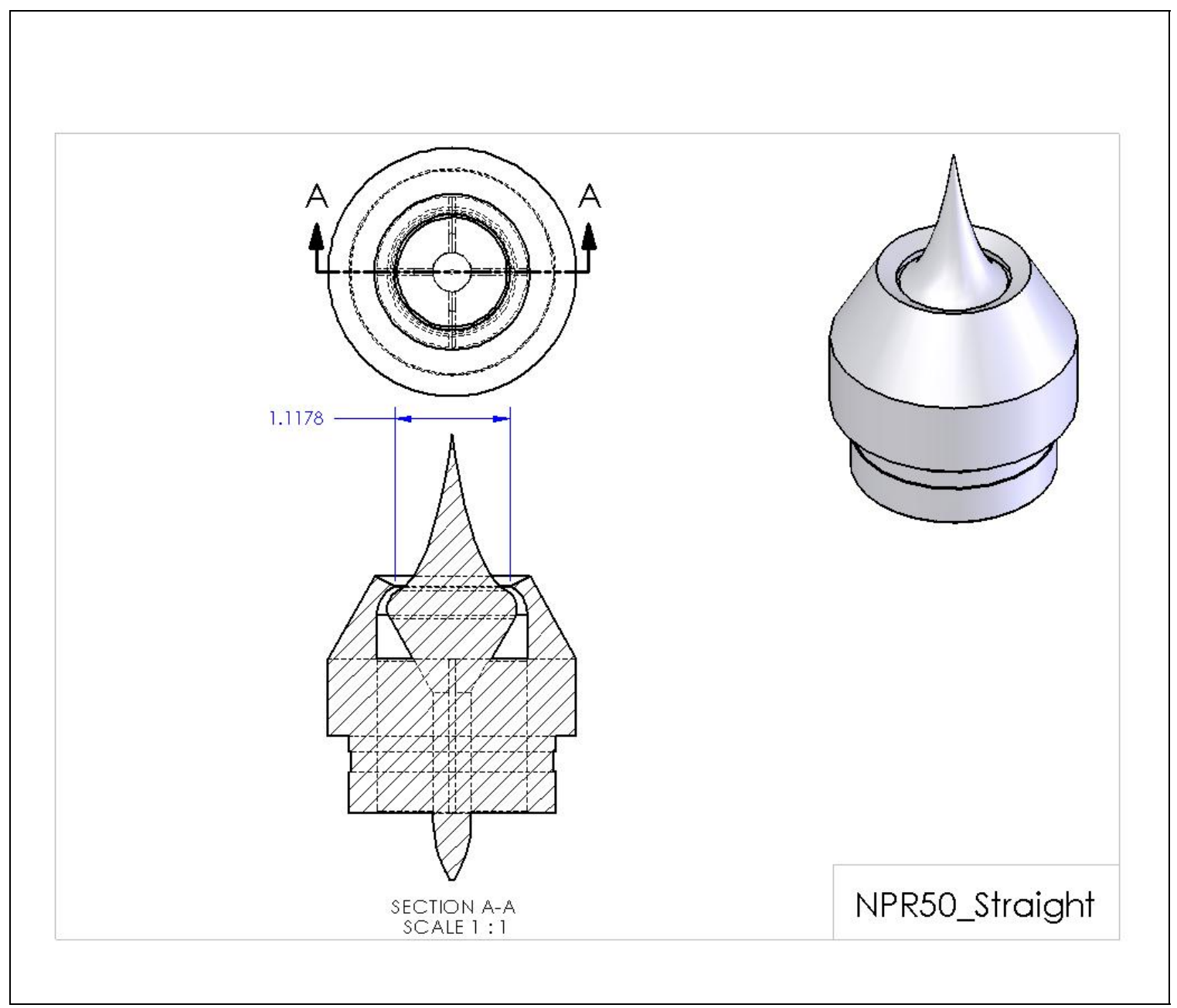

Figure 46. NPR50 Straight design drawing. 


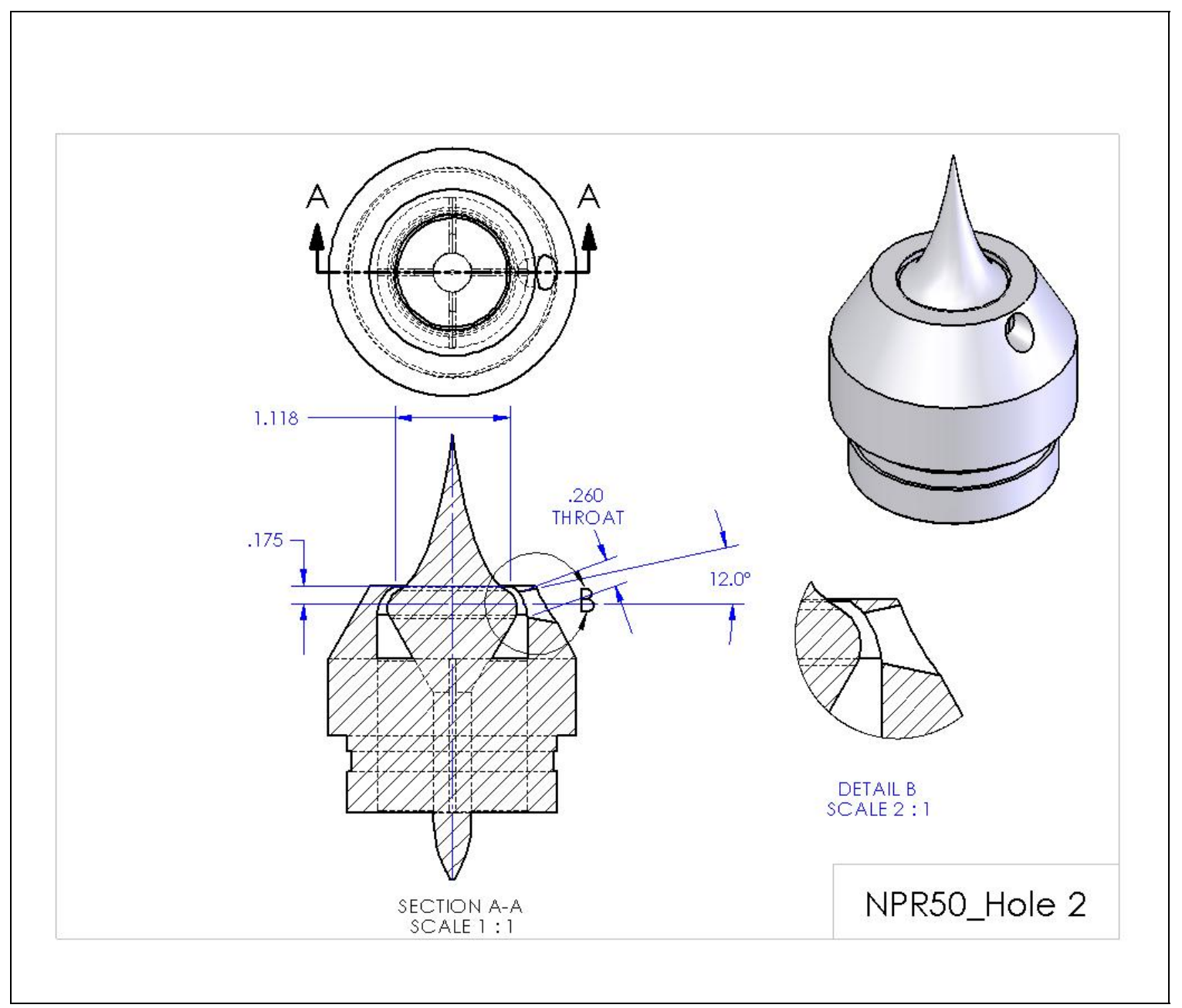

Figure 47. NPR50 Hole 2 design drawing. 


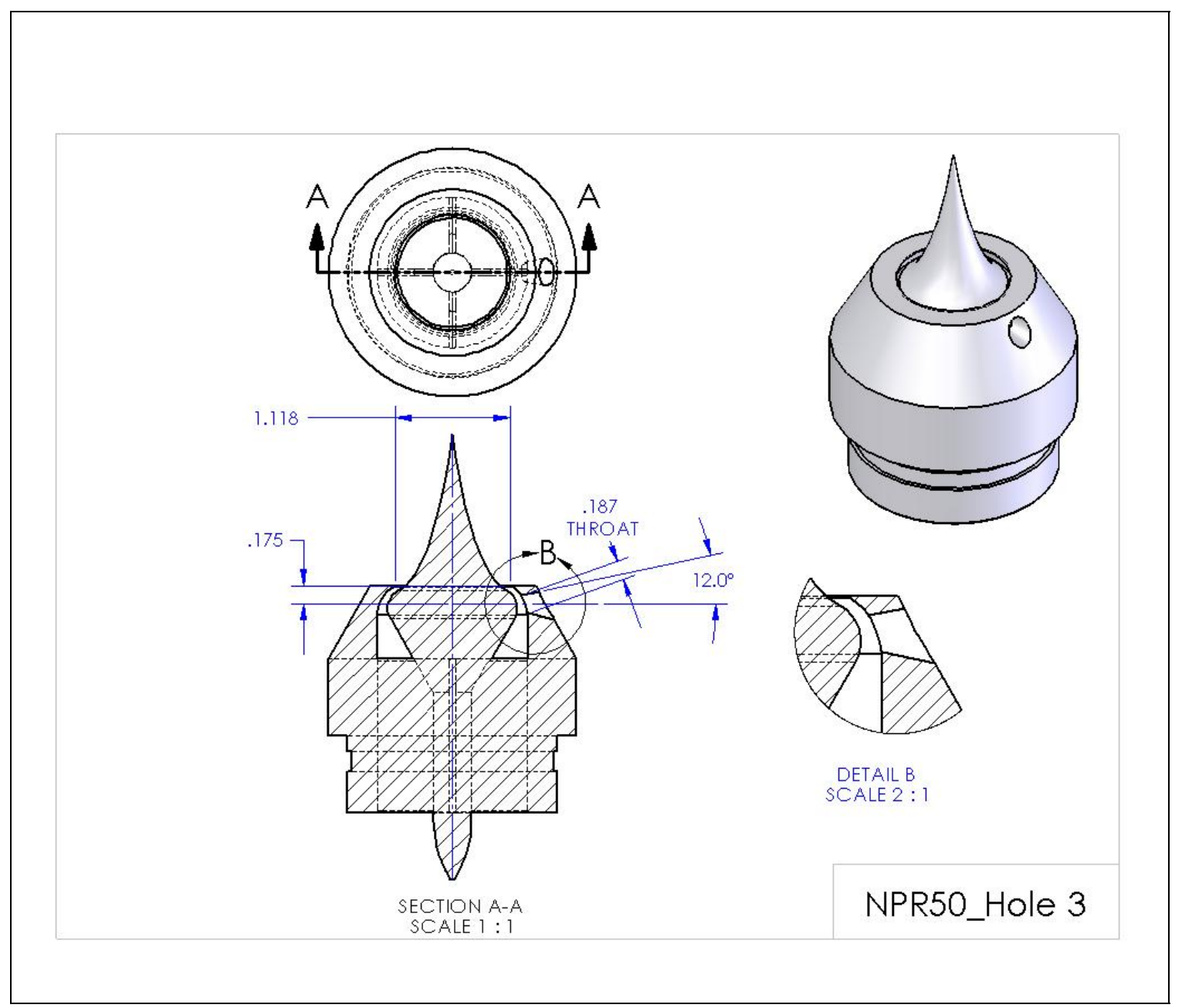

Figure 48. NPR50 Hole 3 design drawing. 


\section{Appendix C: Original Data}

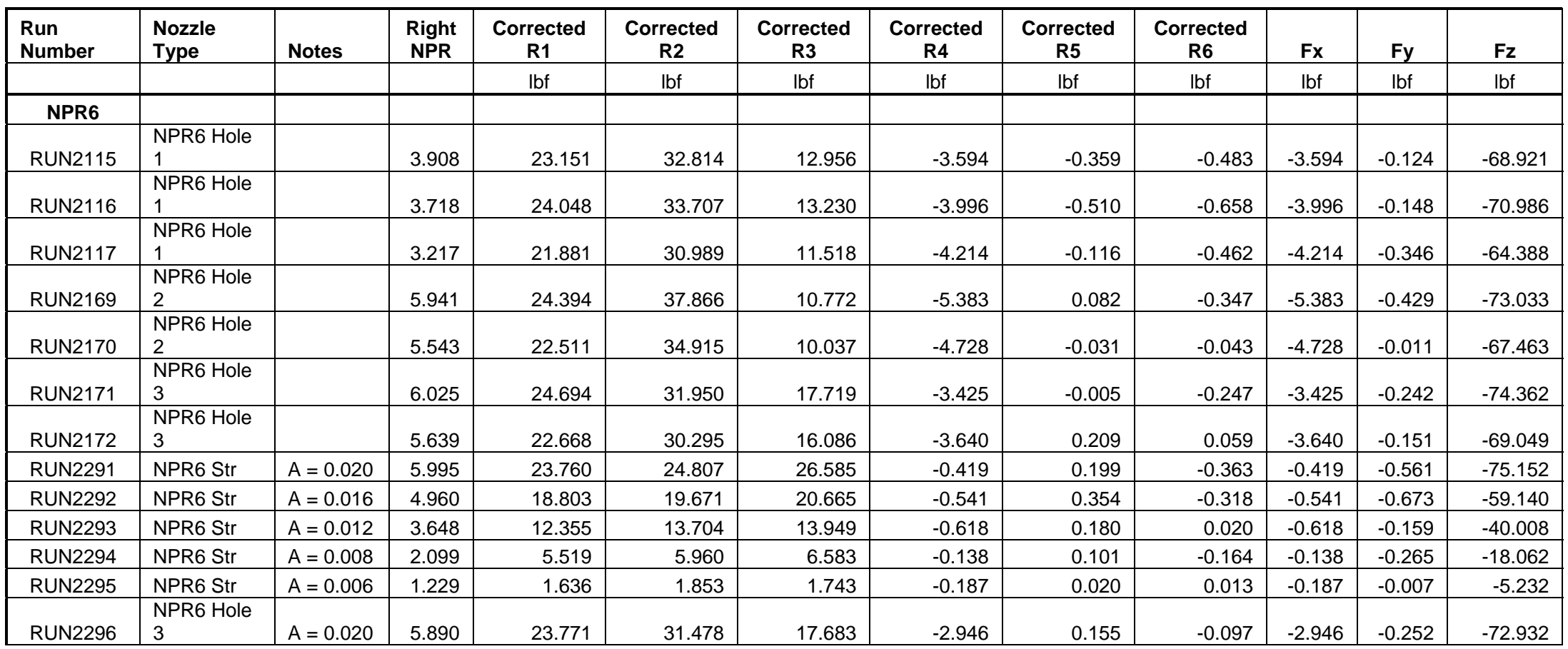




\begin{tabular}{|c|c|c|c|c|c|c|c|c|c|c|c|c|c|c|c|}
\hline $\begin{array}{c}\text { Run } \\
\text { Number }\end{array}$ & $\begin{array}{l}\text { Nozzle } \\
\text { Type }\end{array}$ & Mx & My & Mz & Wp & Wi & $\mathbf{F i}$ & $\mathrm{Fr}$ & $\mathbf{F}_{\text {vector }}$ & $\mathrm{Fr} / \mathrm{Fi}$ & $\mathrm{Fz} / \mathrm{Fi}$ & Wp/Wi & pitch & yaw & $r$ \\
\hline & & in-lbf & in-lbf & in-lbf & $\mathrm{lbm} / \mathrm{s}$ & $\mathrm{lbm} / \mathrm{s}$ & $\mathrm{lbf}$ & $\mathrm{lbf}$ & Ibf & & & & & & \\
\hline \multicolumn{16}{|l|}{ NPR6 } \\
\hline RUN2115 & $\begin{array}{l}\text { NPR6 } \\
\text { Hole } 1\end{array}$ & -1.327 & -86.046 & -3.371 & 1.445 & 1.016 & 64.398 & 69.015 & 3.597 & 1.072 & -1.070 & 1.422 & 0.103 & 2.985 & -2.987 \\
\hline RUN2116 & $\begin{array}{l}\text { NPR6 } \\
\text { Hole } 1 \\
\end{array}$ & -2.897 & -88.727 & -4.670 & 1.503 & 0.966 & 65.973 & 71.099 & 3.998 & 1.078 & -1.076 & 1.555 & 0.119 & 3.222 & -3.224 \\
\hline RUN2117 & $\begin{array}{l}\text { NPR6 } \\
\text { Hole } 1 \\
\end{array}$ & -3.135 & -84.367 & -2.315 & 1.381 & 0.836 & 57.787 & 64.526 & 4.228 & 1.117 & -1.114 & 1.652 & 0.308 & 3.744 & -3.757 \\
\hline RUN2169 & $\begin{array}{l}\text { NPR6 } \\
\text { Hole } 2 \\
\end{array}$ & -0.376 & -117.401 & -1.063 & 1.541 & 1.541 & 76.205 & 73.232 & 5.400 & 0.961 & -0.958 & 1.000 & 0.337 & 4.215 & -4.229 \\
\hline RUN2170 & $\begin{array}{l}\text { NPR6 } \\
\text { Hole } 2 \\
\end{array}$ & -0.178 & -107.794 & -0.295 & 1.438 & 1.436 & 70.104 & 67.629 & 4.728 & 0.965 & -0.962 & 1.001 & 0.010 & 4.009 & -4.009 \\
\hline RUN2171 & $\begin{array}{l}\text { NPR6 } \\
\text { Hole } 3 \\
\end{array}$ & 0.700 & -61.664 & -1.012 & 1.562 & 1.560 & 77.589 & 74.442 & 3.434 & 0.959 & -0.958 & 1.001 & 0.187 & 2.637 & -2.644 \\
\hline RUN2172 & $\begin{array}{l}\text { NPR6 } \\
\text { Hole } 3\end{array}$ & 2.612 & -61.564 & 1.070 & 1.434 & 1.458 & 70.318 & 69.145 & 3.643 & 0.983 & -0.982 & 0.983 & 0.125 & 3.017 & -3.020 \\
\hline RUN2291 & $\begin{array}{l}\text { NPR6 } \\
\text { Str }\end{array}$ & 9.682 & 7.707 & -0.657 & 1.368 & 1.408 & 75.051 & 75.155 & 0.700 & 1.001 & -1.001 & 0.971 & 0.428 & 0.319 & -0.534 \\
\hline RUN2292 & $\begin{array}{l}\text { NPR6 } \\
\text { Str }\end{array}$ & 6.825 & 4.306 & 0.143 & 1.115 & 1.162 & 59.004 & 59.146 & 0.863 & 1.002 & -1.002 & 0.960 & 0.652 & 0.524 & -0.836 \\
\hline RUN2293 & $\begin{array}{l}\text { NPR6 } \\
\text { Str }\end{array}$ & 7.355 & 1.058 & 0.801 & 0.635 & 0.665 & 40.040 & 40.014 & 0.638 & 0.999 & -0.999 & 0.955 & 0.228 & 0.885 & -0.914 \\
\hline RUN2294 & $\begin{array}{l}\text { NPR6 } \\
\text { Str }\end{array}$ & 3.763 & 2.700 & -0.255 & 0.521 & 0.548 & 17.848 & 18.065 & 0.299 & 1.012 & -1.012 & 0.951 & 0.841 & 0.439 & -0.948 \\
\hline RUN2295 & $\begin{array}{l}\text { NPR6 } \\
\text { Str }\end{array}$ & 0.813 & -0.476 & 0.131 & 0.255 & 0.321 & 4.790 & 5.236 & 0.187 & 1.093 & -1.092 & 0.796 & 0.080 & 2.050 & -2.052 \\
\hline RUN2296 & $\begin{array}{l}\text { NPR6 } \\
\text { Hole } 3\end{array}$ & 4.045 & -59.770 & 0.231 & 1.560 & 1.577 & 75.133 & 72.992 & 2.957 & 0.972 & -0.971 & 0.990 & 0.198 & 2.313 & -2.321 \\
\hline
\end{tabular}




\begin{tabular}{|c|c|c|c|c|c|c|c|c|c|c|c|c|}
\hline $\begin{array}{l}\text { Run } \\
\text { Number }\end{array}$ & Nozzle Type & Notes & $\begin{array}{l}\text { Right } \\
\text { NPR }\end{array}$ & $\begin{array}{c}\text { Corrected } \\
\text { R1 } \\
\end{array}$ & $\begin{array}{c}\text { Corrected } \\
\text { R2 } \\
\end{array}$ & $\begin{array}{c}\text { Corrected } \\
\text { R3 }\end{array}$ & $\begin{array}{c}\text { Corrected } \\
\text { R4 } \\
\end{array}$ & $\begin{array}{c}\text { Corrected } \\
\text { R5 } \\
\end{array}$ & $\begin{array}{c}\text { Corrected } \\
\text { R6 }\end{array}$ & $F x$ & Fy & $\mathrm{Fz}$ \\
\hline & & & & Ibf & $\mathrm{lbf}$ & $\mathrm{lbf}$ & $\mathrm{lbf}$ & $\mathrm{lbf}$ & $\mathrm{lbf}$ & $\mathrm{lbf}$ & $\mathrm{lbf}$ & lbf \\
\hline RUN2297 & NPR6 Hole 3 & $A=0.016$ & 4.834 & 18.771 & 25.591 & 13.293 & -3.031 & -0.021 & -0.037 & -3.031 & -0.015 & -57.656 \\
\hline RUN2298 & NPR6 Hole 3 & $A=0.012$ & 3.420 & 12.088 & 16.484 & 8.152 & -1.978 & -0.065 & 0.005 & -1.978 & 0.070 & -36.724 \\
\hline RUN2299 & NPR6 Hole 3 & $A=0.008$ & 2.034 & 5.494 & 7.482 & 3.901 & -0.927 & -0.034 & -0.089 & -0.927 & -0.055 & -16.877 \\
\hline RUN2300 & NPR6 Hole 3 & $A=0.006$ & 1.304 & 2.069 & 2.746 & 1.517 & -0.353 & -0.013 & 0.037 & -0.353 & 0.050 & -6.332 \\
\hline \multicolumn{13}{|l|}{ NPR 20} \\
\hline RUN2016 & $\begin{array}{l}\text { NPR20 } \\
\text { Straight Metal }\end{array}$ & & 7.501 & 8.582 & 8.304 & 9.022 & -0.057 & 0.099 & 0.057 & -0.057 & -0.042 & -25.909 \\
\hline RUN2017 & $\begin{array}{l}\text { NPR20 } \\
\text { Straight Metal }\end{array}$ & & 7.482 & 8.531 & 8.140 & 9.449 & -0.012 & 0.024 & 0.027 & -0.012 & 0.003 & -26.120 \\
\hline RUN2018 & $\begin{array}{l}\text { NPR20 } \\
\text { Straight Metal }\end{array}$ & & 7.505 & 8.550 & 8.187 & 8.589 & 0.018 & 0.026 & 0.030 & 0.018 & 0.004 & -25.326 \\
\hline RUN2019 & $\begin{array}{l}\text { NPR20 } \\
\text { Straight Metal }\end{array}$ & $\begin{array}{l}\text { rotated } 90 \\
\text { degrees cw }\end{array}$ & 7.547 & 8.487 & 8.600 & 9.295 & -0.127 & 0.107 & 0.044 & -0.127 & -0.063 & -26.383 \\
\hline RUN2020 & $\begin{array}{l}\text { NPR20 } \\
\text { Straight Metal }\end{array}$ & $\begin{array}{l}\text { rotated } 90 \\
\text { degrees } \mathrm{cw}\end{array}$ & 7.517 & 8.448 & 8.516 & 8.671 & -0.025 & 0.077 & 0.033 & -0.025 & -0.044 & -25.635 \\
\hline RUN2021 & $\begin{array}{l}\text { NPR20 } \\
\text { Straight Metal }\end{array}$ & $\begin{array}{l}\text { rotated } 90 \\
\text { degrees cw }\end{array}$ & 7.523 & 8.352 & 8.455 & 8.673 & 0.011 & 0.089 & -0.003 & 0.011 & -0.092 & -25.480 \\
\hline RUN2022 & $\begin{array}{l}\text { NPR20 } \\
\text { Straight Metal }\end{array}$ & $\begin{array}{l}\text { rotated } 90 \\
\text { degrees cw }\end{array}$ & 7.473 & 8.339 & 8.466 & 8.874 & -0.099 & 0.026 & 0.021 & -0.099 & -0.005 & -25.680 \\
\hline RUN2023 & $\begin{array}{l}\text { NPR20 } \\
\text { Straight Metal }\end{array}$ & $\begin{array}{l}\text { rotated } 90 \\
\text { degrees cw }\end{array}$ & 7.514 & 8.314 & 8.426 & 9.000 & -0.054 & 0.136 & 0.009 & -0.054 & -0.127 & -25.740 \\
\hline
\end{tabular}




\begin{tabular}{|c|c|c|c|c|c|c|c|c|c|c|c|c|c|c|c|}
\hline $\begin{array}{c}\text { Run } \\
\text { Number }\end{array}$ & $\begin{array}{l}\text { Nozzle } \\
\text { Type }\end{array}$ & Mx & My & $\mathrm{Mz}$ & Wp & Wi & $\mathrm{Fi}$ & $\mathrm{Fr}$ & $\mathbf{F}_{\text {vector }}$ & $\mathrm{Fr} / \mathrm{Fi}$ & $\mathrm{Fz} / \mathrm{Fi}$ & Wp/Wi & pitch & yaw & $r$ \\
\hline & & in-lbf & in-lbf & in-lbf & $\mathrm{lbm} / \mathrm{s}$ & $\mathrm{lbm} / \mathrm{s}$ & lbf & lbf & Ibf & & & & & & \\
\hline RUN2297 & $\begin{array}{l}\text { NPR6 } \\
\text { Hole } 3\end{array}$ & 3.355 & -53.287 & -0.231 & 1.018 & 1.013 & 59.738 & 57.735 & 3.031 & 0.966 & -0.965 & 1.005 & 0.015 & 3.009 & -3.009 \\
\hline RUN2298 & $\begin{array}{l}\text { NPR6 } \\
\text { Hole } 3\end{array}$ & 1.151 & -36.103 & -0.241 & 0.603 & 0.615 & 37.619 & 36.777 & 1.979 & 0.978 & -0.976 & 0.980 & -0.109 & 3.083 & -3.085 \\
\hline RUN2299 & $\begin{array}{l}\text { NPR6 } \\
\text { Hole } 3\end{array}$ & 0.986 & -15.518 & -0.493 & 0.532 & 0.541 & 17.531 & 16.902 & 0.929 & 0.964 & -0.963 & 0.984 & 0.185 & 3.145 & -3.151 \\
\hline RUN2300 & $\begin{array}{l}\text { NPR6 } \\
\text { Hole } 3 \\
\end{array}$ & 0.313 & -5.328 & 0.096 & 0.295 & 0.340 & 6.279 & 6.342 & 0.356 & 1.010 & -1.008 & 0.869 & -0.449 & 3.188 & -3.219 \\
\hline \multicolumn{16}{|l|}{ NPR 20} \\
\hline RUN2016 & $\begin{array}{l}\text { NPR20 } \\
\text { Straight } \\
\text { Metal }\end{array}$ & 0.404 & 3.112 & 0.626 & 0.488 & 0.549 & 25.266 & 25.909 & 0.071 & 1.025 & -1.025 & 0.887 & 0.093 & 0.126 & -0.157 \\
\hline RUN2017 & $\begin{array}{l}\text { NPR20 } \\
\text { Straight } \\
\text { Metal }\end{array}$ & 1.319 & 5.673 & 0.205 & 0.479 & 0.548 & 24.789 & 26.120 & 0.012 & 1.054 & -1.054 & 0.873 & -0.008 & 0.025 & -0.027 \\
\hline RUN2018 & $\begin{array}{l}\text { NPR20 } \\
\text { Straight } \\
\text { Metal }\end{array}$ & -0.811 & 1.743 & 0.225 & 0.506 & 0.550 & 26.208 & 25.326 & 0.018 & 0.966 & -0.966 & 0.920 & -0.009 & -0.041 & -0.042 \\
\hline RUN2019 & $\begin{array}{l}\text { NPR20 } \\
\text { Straight } \\
\text { Metal }\end{array}$ & 2.301 & 3.011 & 0.603 & 0.478 & 0.552 & 24.843 & 26.383 & 0.142 & 1.062 & -1.062 & 0.866 & 0.138 & 0.276 & -0.309 \\
\hline RUN2020 & $\begin{array}{l}\text { NPR20 } \\
\text { Straight } \\
\text { Metal }\end{array}$ & 0.728 & 0.673 & 0.438 & 0.504 & 0.550 & 26.153 & 25.635 & 0.051 & 0.980 & -0.980 & 0.916 & 0.098 & 0.057 & -0.113 \\
\hline RUN2021 & $\begin{array}{l}\text { NPR20 } \\
\text { Straight } \\
\text { Metal }\end{array}$ & 1.060 & 0.945 & 0.345 & 0.483 & 0.550 & 25.070 & 25.480 & 0.092 & 1.016 & -1.016 & 0.877 & 0.207 & -0.024 & -0.208 \\
\hline RUN2022 & $\begin{array}{l}\text { NPR20 } \\
\text { Straight } \\
\text { Metal }\end{array}$ & 1.656 & 1.768 & 0.189 & 0.500 & 0.547 & 25.957 & 25.680 & 0.099 & 0.989 & -0.989 & 0.916 & 0.011 & 0.222 & -0.222 \\
\hline RUN2023 & $\begin{array}{l}\text { NPR20 } \\
\text { Straight } \\
\text { Metal }\end{array}$ & 1.996 & 2.490 & 0.581 & 0.488 & 0.549 & 25.343 & 25.740 & 0.139 & 1.016 & -1.016 & 0.888 & 0.284 & 0.121 & -0.308 \\
\hline
\end{tabular}




\begin{tabular}{|c|c|c|c|c|c|c|c|c|c|c|c|c|}
\hline $\begin{array}{l}\text { Run } \\
\text { Number }\end{array}$ & Nozzle Type & Notes & $\begin{array}{c}\text { Right } \\
\text { NPR }\end{array}$ & $\begin{array}{c}\text { Corrected } \\
\text { R1 } \\
\end{array}$ & $\begin{array}{c}\text { Corrected } \\
\text { R2 } \\
\end{array}$ & $\begin{array}{c}\text { Corrected } \\
\text { R3 }\end{array}$ & $\begin{array}{c}\text { Corrected } \\
\text { R4 } \\
\end{array}$ & $\begin{array}{c}\text { Corrected } \\
\text { R5 }\end{array}$ & $\begin{array}{c}\text { Corrected } \\
\text { R6 }\end{array}$ & Fx & Fy & Fz \\
\hline & & & & $\mathrm{Ibf}$ & $\mathrm{Ibf}$ & $\mathrm{lbf}$ & $\mathrm{lbf}$ & $\mathrm{lbf}$ & $\mathrm{Ibf}$ & Ibf & $\mathrm{lbf}$ & $\mathrm{lbf}$ \\
\hline RUN2024 & $\begin{array}{l}\text { NPR20 } \\
\text { Straight Metal }\end{array}$ & $\begin{array}{l}\text { rotated } 90 \\
\text { degrees } \\
\text { cw }\end{array}$ & 7.461 & 8.357 & 8.434 & 6.922 & -0.080 & 0.074 & 0.036 & -0.080 & -0.038 & -23.713 \\
\hline RUN2025 & $\begin{array}{l}\text { NPR20 } \\
\text { Straight Metal }\end{array}$ & $\begin{array}{l}\text { rotated } 180 \\
\text { degrees } \\
\text { cW }\end{array}$ & 7.499 & 8.539 & 8.168 & 9.222 & 0.029 & 0.017 & 0.031 & 0.029 & 0.013 & -25.929 \\
\hline RUN2026 & $\begin{array}{l}\text { NPR20 } \\
\text { Straight Metal }\end{array}$ & $\begin{array}{l}\text { rotated } 180 \\
\text { degrees } \\
\mathrm{cW}\end{array}$ & 7.490 & 8.545 & 8.154 & 8.747 & 0.025 & 0.113 & 0.090 & 0.025 & -0.023 & -25.447 \\
\hline RUN2027 & $\begin{array}{l}\text { NPR20 } \\
\text { Straight Metal }\end{array}$ & $\begin{array}{l}\text { rotated } 180 \\
\text { degrees } \\
\mathrm{cW}\end{array}$ & 7.512 & 8.552 & 8.239 & 8.875 & -0.041 & 0.071 & 0.100 & -0.041 & 0.029 & -25.666 \\
\hline RUN2028 & $\begin{array}{l}\text { NPR20 } \\
\text { Straight Metal }\end{array}$ & $\begin{array}{l}\text { rotated } 270 \\
\text { degrees } \\
\text { cW }\end{array}$ & 7.485 & 8.521 & 8.388 & 7.417 & -0.026 & 0.079 & 0.036 & -0.026 & -0.043 & -24.327 \\
\hline RUN2029 & $\begin{array}{l}\text { NPR20 } \\
\text { Straight Metal }\end{array}$ & $\begin{array}{l}\text { rotated } 270 \\
\text { degrees } \\
\mathrm{cW}\end{array}$ & 7.500 & 8.471 & 8.289 & 8.715 & 0.010 & 0.104 & 0.062 & 0.010 & -0.042 & -25.476 \\
\hline RUN2030 & $\begin{array}{l}\text { NPR20 } \\
\text { Straight Metal }\end{array}$ & $\begin{array}{l}\text { rotated } 270 \\
\text { degrees } \\
\mathrm{cW}\end{array}$ & 7.490 & 8.460 & 8.156 & 8.349 & 0.029 & 0.076 & 0.048 & 0.029 & -0.028 & -24.966 \\
\hline RUN2039 & $\begin{array}{l}\text { NPR20 } \\
\text { Straight }\end{array}$ & & 7.392 & 9.372 & 8.223 & 10.176 & 0.217 & 0.049 & 0.085 & 0.217 & 0.036 & -27.770 \\
\hline RUN2040 & $\begin{array}{l}\text { NPR20 } \\
\text { Straight }\end{array}$ & & 7.518 & 9.575 & 8.491 & 9.667 & 0.178 & 0.019 & 0.029 & 0.178 & 0.010 & -27.734 \\
\hline RUN2041 & $\begin{array}{l}\text { NPR20 } \\
\text { Straight }\end{array}$ & $\begin{array}{l}\text { rotated } 90 \\
\text { degrees } \\
\mathrm{CW}\end{array}$ & 7.063 & 7.998 & 8.657 & 8.899 & 0.039 & 0.131 & -0.078 & 0.039 & -0.209 & -25.553 \\
\hline RUN2042 & $\begin{array}{l}\text { NPR20 } \\
\text { Straight }\end{array}$ & $\begin{array}{l}\text { rotated } 90 \\
\text { degrees } \\
\mathrm{CW}\end{array}$ & 7.485 & 8.611 & 9.276 & 10.257 & 0.038 & 0.145 & -0.072 & 0.038 & -0.217 & -28.144 \\
\hline RUN2043 & $\begin{array}{l}\text { NPR20 } \\
\text { Straight }\end{array}$ & $\begin{array}{l}\text { rotated } 180 \\
\text { degrees } \\
\mathrm{CW}\end{array}$ & 7.413 & 9.040 & 9.745 & 9.385 & -0.220 & 0.103 & 0.035 & -0.220 & -0.068 & -28.170 \\
\hline RUN2044 & $\begin{array}{l}\text { NPR20 } \\
\text { Straight }\end{array}$ & $\begin{array}{l}\text { rotated } 180 \\
\text { degrees } \\
\mathrm{CW}\end{array}$ & 7.486 & 9.103 & 9.840 & 8.826 & -0.259 & 0.076 & 0.046 & -0.259 & -0.029 & -27.769 \\
\hline
\end{tabular}




\begin{tabular}{|c|c|c|c|c|c|c|c|c|c|c|c|c|c|c|c|}
\hline $\begin{array}{c}\text { Run } \\
\text { Number }\end{array}$ & $\begin{array}{l}\text { Nozzle } \\
\text { Type }\end{array}$ & $\mathrm{Mx}$ & My & Mz & Wp & Wi & $\mathrm{Fi}$ & $\mathrm{Fr}$ & $\mathbf{F}_{\text {vector }}$ & $\mathrm{Fr} / \mathrm{Fi}$ & $\mathrm{Fz} / \mathrm{Fi}$ & Wp/Wi & pitch & yaw & $\mathrm{r}$ \\
\hline & & in-lbf & in-lbf & in-lbf & $\mathrm{lbm} / \mathrm{s}$ & $\mathrm{lbm} / \mathrm{s}$ & Ibf & $\mathrm{lbf}$ & $\mathrm{lbf}$ & & & & & & \\
\hline RUN2024 & $\begin{array}{l}\text { NPR20 } \\
\text { Straight } \\
\text { Metal }\end{array}$ & -3.392 & -6.551 & 0.442 & 0.471 & 0.546 & 24.408 & 23.713 & 0.089 & 0.972 & -0.971 & 0.863 & 0.091 & 0.194 & -0.214 \\
\hline RUN2025 & $\begin{array}{l}\text { NPR20 } \\
\text { Straight } \\
\text { Metal }\end{array}$ & 0.783 & 4.565 & 0.192 & 0.488 & 0.548 & 25.337 & 25.929 & 0.032 & 1.023 & -1.023 & 0.890 & -0.029 & -0.065 & -0.071 \\
\hline RUN2026 & $\begin{array}{l}\text { NPR20 } \\
\text { Straight } \\
\text { Metal }\end{array}$ & -0.470 & 2.569 & 0.810 & 0.512 & 0.547 & 26.567 & 25.447 & 0.034 & 0.958 & -0.958 & 0.935 & 0.052 & -0.057 & -0.077 \\
\hline RUN2027 & $\begin{array}{l}\text { NPR20 } \\
\text { Straight } \\
\text { Metal }\end{array}$ & 0.026 & 2.754 & 0.683 & 0.501 & 0.549 & 26.056 & 25.666 & 0.050 & 0.985 & -0.985 & 0.913 & -0.064 & 0.090 & -0.111 \\
\hline RUN2028 & $\begin{array}{l}\text { NPR20 } \\
\text { Straight } \\
\text { Metal }\end{array}$ & -3.093 & -4.210 & 0.460 & 0.504 & 0.547 & 26.164 & 24.327 & 0.050 & 0.930 & -0.930 & 0.921 & 0.101 & 0.060 & -0.117 \\
\hline RUN2029 & $\begin{array}{l}\text { NPR20 } \\
\text { Straight } \\
\text { Metal }\end{array}$ & 0.155 & 1.846 & 0.662 & 0.456 & 0.548 & 23.690 & 25.476 & 0.043 & 1.075 & -1.075 & 0.832 & 0.095 & -0.023 & -0.098 \\
\hline RUN2030 & $\begin{array}{l}\text { NPR20 } \\
\text { Straight } \\
\text { Metal }\end{array}$ & -1.037 & 0.835 & 0.496 & 0.486 & 0.547 & 25.256 & 24.966 & 0.040 & 0.989 & -0.989 & 0.889 & 0.064 & -0.067 & -0.093 \\
\hline RUN2039 & $\begin{array}{l}\text { NPR20 } \\
\text { Straight }\end{array}$ & -0.864 & 8.462 & 0.533 & 0.540 & 0.541 & 27.956 & 27.771 & 0.220 & 0.993 & -0.993 & 0.997 & -0.074 & -0.448 & -0.454 \\
\hline RUN2040 & $\begin{array}{l}\text { NPR20 } \\
\text { Straight }\end{array}$ & -2.481 & 5.097 & 0.195 & 0.538 & 0.550 & 27.949 & 27.734 & 0.178 & 0.992 & -0.992 & 0.978 & -0.020 & -0.367 & -0.368 \\
\hline RUN2041 & $\begin{array}{l}\text { NPR20 } \\
\text { Straight }\end{array}$ & 3.900 & 1.047 & 0.213 & 0.544 & 0.516 & 27.957 & 25.554 & 0.213 & 0.914 & -0.914 & 1.053 & 0.470 & -0.087 & -0.478 \\
\hline RUN2042 & $\begin{array}{l}\text { NPR20 } \\
\text { Straight }\end{array}$ & 5.778 & 4.254 & 0.290 & 0.560 & 0.547 & 29.127 & 28.145 & 0.220 & 0.966 & -0.966 & 1.024 & 0.441 & -0.078 & -0.448 \\
\hline RUN2043 & $\begin{array}{l}\text { NPR20 } \\
\text { Straight }\end{array}$ & 2.627 & -1.556 & 0.553 & 0.507 & 0.542 & 26.304 & 28.171 & 0.230 & 1.071 & -1.071 & 0.936 & 0.138 & 0.448 & -0.468 \\
\hline RUN2044 & $\begin{array}{l}\text { NPR20 } \\
\text { Straight }\end{array}$ & 1.151 & -4.394 & 0.489 & 0.547 & 0.547 & 28.446 & 27.771 & 0.260 & 0.976 & -0.976 & 1.000 & 0.060 & 0.534 & -0.537 \\
\hline
\end{tabular}




\begin{tabular}{|c|c|c|c|c|c|c|c|c|c|c|c|c|}
\hline $\begin{array}{l}\text { Run } \\
\text { Number }\end{array}$ & Nozzle Type & Notes & $\begin{array}{l}\text { Right } \\
\text { NPR }\end{array}$ & $\begin{array}{c}\text { Corrected } \\
\text { R1 }\end{array}$ & $\begin{array}{c}\text { Corrected } \\
\text { R2 } \\
\end{array}$ & $\begin{array}{c}\text { Corrected } \\
\text { R3 }\end{array}$ & $\begin{array}{c}\text { Corrected } \\
\text { R4 }\end{array}$ & $\begin{array}{c}\text { Corrected } \\
\text { R5 }\end{array}$ & $\begin{array}{c}\text { Corrected } \\
\text { R6 }\end{array}$ & $F x$ & Fy & $\mathbf{F z}$ \\
\hline & & & & $\mathrm{lbf}$ & $\mathrm{Ibf}$ & $\mathrm{Ibf}$ & $\mathrm{lbf}$ & $\mathrm{lbf}$ & $\mathrm{lbf}$ & $\mathrm{lbf}$ & $\mathrm{lbf}$ & $\mathrm{Ibf}$ \\
\hline RUN2045 & $\begin{array}{l}\text { NPR20 } \\
\text { Straight }\end{array}$ & $\begin{array}{l}\text { rotated } 270 \\
\text { degrees } \\
\mathrm{CW}\end{array}$ & 7.541 & 10.123 & 8.976 & 8.483 & -0.032 & -0.064 & 0.125 & -0.032 & 0.190 & -27.581 \\
\hline RUN2046 & $\begin{array}{l}\text { NPR20 } \\
\text { Straight }\end{array}$ & $\begin{array}{l}\text { rotated } 270 \\
\text { degrees } \\
\mathrm{CW}\end{array}$ & 7.392 & 9.780 & 8.817 & 9.066 & -0.132 & 0.000 & 0.175 & -0.132 & 0.176 & -27.662 \\
\hline RUN2160 & $\begin{array}{l}\text { NPR20 } \\
\text { Straight Metal }\end{array}$ & & 7.455 & 8.500 & 8.214 & 8.747 & 0.106 & 0.097 & 0.038 & 0.106 & -0.060 & -25.461 \\
\hline RUN2161 & $\begin{array}{l}\text { NPR20 } \\
\text { Straight Metal }\end{array}$ & & 7.450 & 8.487 & 8.375 & 8.827 & -0.050 & 0.070 & 0.059 & -0.050 & -0.012 & -25.689 \\
\hline RUN2162 & $\begin{array}{l}\text { NPR20 } \\
\text { Straight Metal }\end{array}$ & & 7.494 & 8.591 & 8.422 & 8.775 & 0.027 & 0.064 & 0.060 & 0.027 & -0.003 & -25.787 \\
\hline RUN2163 & $\begin{array}{l}\text { NPR20 } \\
\text { Straight Metal } \\
(\text { Stan 1) }\end{array}$ & & 7.465 & 9.955 & 9.856 & 10.272 & -0.053 & 0.100 & 0.068 & -0.053 & -0.031 & -30.084 \\
\hline RUN2164 & $\begin{array}{l}\text { NPR20 } \\
\text { Straight Metal } \\
\text { (Stan 1) }\end{array}$ & & 7.458 & 9.816 & 9.806 & 10.112 & -0.097 & 0.052 & 0.010 & -0.097 & -0.042 & -29.734 \\
\hline RUN2165 & $\begin{array}{l}\text { NPR20 } \\
\text { Straight Metal } \\
\text { (Stan 1) }\end{array}$ & & 7.453 & 9.877 & 9.767 & 10.192 & -0.080 & 0.081 & 0.054 & -0.080 & -0.026 & -29.836 \\
\hline RUN2166 & $\begin{array}{l}\text { NPR20 } \\
\text { Straight Metal } \\
\text { (Stan 2) }\end{array}$ & & 7.459 & 11.060 & 10.343 & 11.250 & -0.089 & 0.061 & 0.081 & -0.089 & 0.020 & -32.654 \\
\hline RUN2167 & $\begin{array}{l}\text { NPR20 } \\
\text { Straight Metal } \\
\text { (Stan 2) }\end{array}$ & & 7.469 & 11.099 & 10.484 & 10.923 & -0.085 & 0.057 & 0.091 & -0.085 & 0.034 & -32.506 \\
\hline RUN2168 & $\begin{array}{l}\text { NPR20 } \\
\text { Straight Metal } \\
\text { (Stan 2) }\end{array}$ & & 7.451 & 11.026 & 10.322 & 10.956 & 0.016 & 0.037 & 0.132 & 0.016 & 0.095 & -32.303 \\
\hline RUN2177 & $\begin{array}{l}\text { NPR20 Hole } \\
2\end{array}$ & & 7.492 & 9.948 & 25.421 & -6.722 & -5.452 & 0.010 & 0.112 & -5.452 & 0.102 & -28.647 \\
\hline RUN2178 & $\begin{array}{l}\text { NPR20 Hole } \\
2\end{array}$ & & 7.467 & 9.858 & 25.661 & -6.701 & -5.447 & 0.068 & 0.043 & -5.447 & -0.025 & -28.818 \\
\hline
\end{tabular}




\begin{tabular}{|c|c|c|c|c|c|c|c|c|c|c|c|c|c|c|c|}
\hline $\begin{array}{c}\text { Run } \\
\text { Number }\end{array}$ & Nozzle Type & $\mathrm{Mx}$ & My & Mz & Wp & Wi & $\mathrm{Fi}$ & $\mathrm{Fr}$ & $\mathbf{F}_{\text {vector }}$ & Fr/Fi & $\mathrm{Fz} / \mathrm{Fi}$ & Wp/Wi & pitch & yaw & $\mathrm{r}$ \\
\hline & & in-lbf & in-lbf & in-lbf & $\mathrm{lbm} / \mathrm{s}$ & $\mathrm{lbm} / \mathrm{s}$ & $\mathrm{lbf}$ & $\mathrm{lbf}$ & $\mathrm{lbf}$ & & & & & & \\
\hline RUN2045 & NPR20 Straight & -6.967 & -2.137 & 0.246 & 0.574 & 0.551 & 29.914 & 27.582 & 0.192 & 0.922 & -0.922 & 1.043 & -0.394 & 0.065 & -0.399 \\
\hline RUN2046 & NPR20 Straight & -4.193 & 1.079 & 0.700 & 0.558 & 0.540 & 28.992 & 27.663 & 0.220 & 0.954 & -0.954 & 1.035 & -0.364 & 0.273 & -0.455 \\
\hline RUN2160 & NPR20 Straight Metal & -0.095 & 2.309 & 0.541 & 0.467 & 0.546 & 24.166 & 25.461 & 0.121 & 1.054 & -1.054 & 0.855 & 0.134 & -0.238 & -0.273 \\
\hline RUN2161 & NPR20 Straight Metal & 0.569 & 1.956 & 0.515 & 0.498 & 0.546 & 25.743 & 25.689 & 0.051 & 0.998 & -0.998 & 0.912 & 0.026 & 0.111 & -0.114 \\
\hline RUN2162 & NPR20 Straight Metal & 0.039 & 1.533 & 0.497 & 0.510 & 0.549 & 26.407 & 25.787 & 0.027 & 0.977 & -0.977 & 0.929 & 0.007 & -0.060 & -0.060 \\
\hline RUN2163 & NPR20 Straight Metal (Stan 1) & 0.545 & 1.804 & 0.671 & 0.596 & 0.547 & 30.861 & 30.084 & 0.062 & 0.975 & -0.975 & 1.090 & 0.060 & 0.101 & -0.117 \\
\hline RUN2164 & NPR20 Straight Metal (Stan 1) & 0.715 & 1.327 & 0.249 & 0.582 & 0.546 & 30.126 & 29.734 & 0.106 & 0.987 & -0.987 & 1.066 & 0.082 & 0.187 & -0.204 \\
\hline RUN2165 & NPR20 Straight Metal (Stan 1) & 0.515 & 1.841 & 0.540 & 0.591 & 0.546 & 30.577 & 29.836 & 0.084 & 0.976 & -0.976 & 1.082 & 0.051 & 0.153 & -0.161 \\
\hline RUN2166 & NPR20 Straight Metal (Stan 2) & -1.317 & 3.929 & 0.565 & 0.587 & 0.546 & 30.424 & 32.654 & 0.091 & 1.073 & -1.073 & 1.076 & -0.035 & 0.155 & -0.159 \\
\hline RUN2167 & NPR20 Straight Metal (Stan 2) & -1.977 & 1.900 & 0.592 & 0.603 & 0.547 & 31.246 & 32.507 & 0.091 & 1.040 & -1.040 & 1.103 & -0.059 & 0.150 & -0.161 \\
\hline RUN2168 & NPR20 Straight Metal (Stan 2) & -1.934 & 2.749 & 0.678 & 0.635 & 0.545 & 32.866 & 32.304 & 0.097 & 0.983 & -0.983 & 1.164 & -0.169 & -0.028 & -0.171 \\
\hline RUN2177 & NPR20 Hole 2 & -2.996 & 139.276 & 0.491 & 0.651 & 0.545 & 33.826 & 29.161 & 5.453 & 0.862 & -0.847 & 1.194 & -0.204 & 10.775 & 10.777 \\
\hline RUN2178 & NPR20 Hole 2 & -1.890 & 140.222 & 0.446 & 0.635 & 0.543 & 32.986 & 29.328 & 5.447 & 0.889 & -0.874 & 1.169 & 0.050 & 10.704 & 10.704 \\
\hline
\end{tabular}




\begin{tabular}{|c|c|c|c|c|c|c|c|c|c|c|c|c|}
\hline $\begin{array}{l}\text { Run } \\
\text { Number }\end{array}$ & Nozzle Type & Notes & $\begin{array}{l}\text { Right } \\
\text { NPR }\end{array}$ & $\begin{array}{c}\text { Corrected } \\
\text { R1 }\end{array}$ & $\begin{array}{c}\text { Corrected } \\
\text { R2 } \\
\end{array}$ & $\begin{array}{c}\text { Corrected } \\
\text { R3 }\end{array}$ & $\begin{array}{c}\text { Corrected } \\
\text { R4 }\end{array}$ & $\begin{array}{c}\text { Corrected } \\
\text { R5 }\end{array}$ & $\begin{array}{c}\text { Corrected } \\
\text { R6 }\end{array}$ & $F x$ & Fy & $\mathbf{F z}$ \\
\hline & & & & $\mathrm{lbf}$ & $\mathrm{lbf}$ & $\mathrm{lbf}$ & $\mathrm{lbf}$ & $\mathrm{lbf}$ & $\mathrm{lbf}$ & $\mathrm{lbf}$ & $\mathrm{lbf}$ & $\mathrm{Ibf}$ \\
\hline RUN2179 & $\begin{array}{l}\text { NPR20 Hole } \\
2\end{array}$ & & 7.458 & 10.061 & 25.125 & -6.644 & -5.332 & -0.037 & 0.123 & -5.332 & 0.159 & -28.542 \\
\hline RUN2180 & $\begin{array}{l}\text { NPR20 Hole } \\
3\end{array}$ & & 7.463 & 10.046 & 18.557 & 0.471 & -3.172 & 0.024 & 0.061 & -3.172 & 0.037 & -29.073 \\
\hline RUN2181 & $\begin{array}{l}\text { NPR20 Hole } \\
3\end{array}$ & & 7.472 & 10.062 & 18.469 & 0.505 & -3.118 & 0.037 & 0.124 & -3.118 & 0.088 & -29.035 \\
\hline RUN2182 & $\begin{array}{l}\text { NPR20 Hole } \\
3 \\
\end{array}$ & & 7.473 & 10.252 & 17.777 & 0.758 & -2.940 & 0.003 & 0.160 & -2.940 & 0.156 & -28.787 \\
\hline RUN2204 & $\begin{array}{l}\text { NPR20 } \\
\text { Straight Metal }\end{array}$ & & 7.488 & 8.461 & 8.454 & 8.779 & -0.024 & 0.127 & 0.067 & -0.024 & -0.059 & -25.694 \\
\hline RUN2205 & $\begin{array}{l}\text { NPR20 } \\
\text { Straight Metal } \\
\text { (Stan 1) }\end{array}$ & & 7.446 & 9.911 & 9.779 & 10.062 & -0.056 & 0.085 & 0.086 & -0.056 & 0.001 & -29.752 \\
\hline RUN2219 & $\begin{array}{l}\text { NPR20 Hole } \\
5\end{array}$ & $\begin{array}{l}\text { Inlet } \\
\text { Radius = } \\
0.050\end{array}$ & 7.469 & 10.580 & 21.971 & -3.610 & -4.319 & -0.083 & 0.231 & -4.319 & 0.314 & -28.940 \\
\hline RUN2220 & $\begin{array}{l}\text { NPR20 Hole } \\
5\end{array}$ & $\begin{array}{l}\text { Inlet } \\
\text { Radius = } \\
0.050 \\
\end{array}$ & 7.467 & 10.671 & 21.839 & -3.624 & -4.382 & -0.100 & 0.166 & -4.382 & 0.266 & -28.886 \\
\hline RUN2221 & $\begin{array}{l}\text { NPR20 Hole } \\
6\end{array}$ & $\begin{array}{l}\text { Inlet } \\
\text { Radius = } \\
0.075\end{array}$ & 7.428 & 10.254 & 23.375 & -5.181 & -4.863 & -0.037 & 0.184 & -4.863 & 0.221 & -28.449 \\
\hline RUN2222 & $\begin{array}{l}\text { NPR20 Hole } \\
6\end{array}$ & $\begin{array}{l}\text { Inlet } \\
\text { Radius = } \\
0.075\end{array}$ & 7.498 & 10.517 & 23.411 & -4.995 & -4.793 & -0.054 & 0.177 & -4.793 & 0.231 & -28.933 \\
\hline RUN2223 & $\begin{array}{l}\text { NPR20 Hole } \\
7\end{array}$ & $\begin{array}{l}\text { Inlet } \\
\text { Radius = } \\
0.025\end{array}$ & 7.471 & 10.199 & 21.769 & -3.387 & -4.369 & 0.006 & 0.194 & -4.369 & 0.189 & -28.582 \\
\hline RUN2224 & $\begin{array}{l}\text { NPR20 Hole } \\
7\end{array}$ & $\begin{array}{l}\text { Inlet } \\
\text { Radius = } \\
0.025\end{array}$ & 7.460 & 10.272 & 21.665 & -3.347 & -4.304 & -0.078 & 0.156 & -4.304 & 0.234 & -28.591 \\
\hline RUN2230 & $\begin{array}{l}\text { NPR20 Hole } \\
3\end{array}$ & & 7.468 & 10.172 & 18.647 & 0.242 & -3.296 & 0.016 & 0.162 & -3.296 & 0.146 & -29.061 \\
\hline
\end{tabular}




\begin{tabular}{|c|c|c|c|c|c|c|c|c|c|c|c|c|c|c|c|}
\hline $\begin{array}{c}\text { Run } \\
\text { Number }\end{array}$ & Nozzle Type & $\mathrm{Mx}$ & My & $\mathrm{Mz}$ & Wp & Wi & $\mathbf{F i}$ & $\mathrm{Fr}$ & $\mathbf{F}_{\text {vector }}$ & $\mathrm{Fr} / \mathrm{Fi}$ & $\mathrm{Fz} / \mathrm{Fi}$ & Wp/Wi & pitch & yaw & $r$ \\
\hline & & in-lbf & in-lbf & in-lbf & $\mathrm{lbm} / \mathrm{s}$ & $\mathrm{lbm} / \mathrm{s}$ & $\mathrm{lbf}$ & $\mathrm{lbf}$ & $\mathrm{lbf}$ & & & & & & \\
\hline RUN2179 & NPR20 Hole 2 & -4.104 & -137.654 & 0.344 & 0.659 & 0.543 & 34.232 & 29.036 & 5.335 & 0.848 & -0.834 & 1.215 & -0.320 & 10.583 & -10.587 \\
\hline RUN2180 & NPR20 Hole 3 & -2.662 & -78.367 & 0.341 & 0.647 & 0.543 & 33.592 & 29.246 & 3.172 & 0.871 & -0.865 & 1.191 & -0.074 & 6.227 & -6.227 \\
\hline RUN2181 & NPR20 Hole 3 & -2.878 & -77.838 & 0.644 & 0.618 & 0.544 & 32.098 & 29.203 & 3.120 & 0.910 & -0.905 & 1.137 & -0.173 & 6.130 & -6.132 \\
\hline RUN2182 & NPR20 Hole 3 & -4.925 & -73.745 & 0.653 & 0.627 & 0.544 & 32.548 & 28.937 & 2.944 & 0.889 & -0.884 & 1.152 & -0.311 & 5.830 & -5.839 \\
\hline RUN2204 & NPR20 Straight Metal & 0.780 & 1.408 & 0.776 & 0.489 & 0.543 & 25.490 & 25.694 & 0.064 & 1.008 & -1.008 & 0.900 & 0.132 & 0.054 & -0.143 \\
\hline RUN2205 & $\begin{array}{l}\text { NPR20 Straight Metal } \\
\text { (Stan 1) }\end{array}$ & 0.047 & 1.226 & 0.684 & 0.578 & 0.540 & 30.075 & 29.752 & 0.056 & 0.989 & -0.989 & 1.069 & -0.002 & 0.108 & -0.108 \\
\hline RUN2219 & NPR20 Hole 5 & -6.999 & -110.842 & 0.595 & 0.665 & 0.545 & 34.567 & 29.262 & 4.330 & 0.847 & -0.837 & 1.221 & -0.621 & 8.487 & -8.509 \\
\hline RUN2220 & NPR20 Hole 5 & -7.820 & -110.331 & 0.261 & 0.615 & 0.544 & 31.956 & 29.218 & 4.390 & 0.914 & -0.904 & 1.129 & -0.528 & 8.625 & -8.641 \\
\hline RUN2221 & NPR20 Hole 6 & -5.784 & -123.731 & 0.588 & 0.622 & 0.541 & 32.334 & 28.862 & 4.868 & 0.893 & -0.880 & 1.149 & -0.445 & 9.700 & -9.710 \\
\hline RUN2222 & NPR20 Hole 6 & -6.544 & -123.084 & 0.492 & 0.637 & 0.546 & 33.151 & 29.328 & 4.798 & 0.885 & -0.873 & 1.166 & -0.456 & 9.406 & -9.417 \\
\hline RUN2223 & NPR20 Hole 7 & -5.040 & -109.002 & 0.800 & 0.652 & 0.544 & 33.947 & 28.914 & 4.373 & 0.852 & -0.842 & 1.199 & -0.378 & 8.691 & -8.699 \\
\hline RUN2224 & NPR20 Hole 7 & -5.563 & -108.376 & 0.309 & 0.652 & 0.543 & 33.944 & 28.914 & 4.310 & 0.852 & -0.842 & 1.201 & -0.469 & 8.560 & -8.573 \\
\hline RUN2230 & NPR20 Hole 3 & -3.638 & -79.747 & 0.711 & 0.629 & 0.543 & 32.773 & 29.248 & 3.299 & 0.892 & -0.887 & 1.158 & -0.287 & 6.470 & -6.476 \\
\hline
\end{tabular}




\begin{tabular}{|c|c|c|c|c|c|c|c|c|c|c|c|c|}
\hline $\begin{array}{l}\text { Run } \\
\text { Number }\end{array}$ & Nozzle Type & Notes & $\begin{array}{c}\text { Right } \\
\text { NPR }\end{array}$ & $\begin{array}{c}\text { Corrected } \\
\text { R1 } \\
\end{array}$ & $\begin{array}{c}\text { Corrected } \\
\text { R2 } \\
\end{array}$ & $\begin{array}{c}\text { Corrected } \\
\text { R3 } \\
\end{array}$ & $\begin{array}{c}\text { Corrected } \\
\text { R4 } \\
\end{array}$ & $\begin{array}{c}\text { Corrected } \\
\text { R5 } \\
\end{array}$ & $\begin{array}{c}\text { Corrected } \\
\text { R6 } \\
\end{array}$ & $F x$ & Fy & $\mathrm{Fz}$ \\
\hline & & & & $\mathrm{lbf}$ & $\mathrm{lbf}$ & $\mathrm{lbf}$ & $\mathrm{lbf}$ & $\mathrm{lbf}$ & lbf & $\mathrm{lbf}$ & $\mathrm{lbf}$ & $\mathrm{lbf}$ \\
\hline RUN2081 & NPR20 Hole & & 7.526 & 8.947 & 14.772 & 4.141 & -1.780 & 0.083 & -0.046 & -1.780 & -0.129 & -27.861 \\
\hline RUN2082 & NPR20 Hole & & 7.496 & 8.877 & 14.533 & 4.388 & -1.789 & 0.067 & -0.004 & -1.789 & -0.072 & -27.798 \\
\hline RUN2083 & NPR20 Hole & & 7.484 & 8.823 & 14.717 & 4.287 & -1.759 & 0.086 & -0.014 & -1.759 & -0.100 & -27.827 \\
\hline RUN2084 & NPR20 Hole & $\begin{array}{l}\text { rotated } 90 \\
\text { degrees } \\
\mathrm{CW}\end{array}$ & 7.485 & 15.530 & 6.592 & 5.919 & -0.186 & -0.804 & 0.889 & -0.186 & 1.693 & -28.040 \\
\hline RUN2085 & NPR20 Hole & $\begin{array}{l}\text { rotated } 90 \\
\text { degrees } \\
\mathrm{CW}\end{array}$ & 7.488 & 15.494 & 6.694 & 5.978 & -0.217 & -0.833 & 0.921 & -0.217 & 1.754 & -28.166 \\
\hline RUN2086 & NPR20 Hole & $\begin{array}{l}\text { rotated } 90 \\
\text { degrees } \\
\mathrm{CW}\end{array}$ & 7.497 & 15.533 & 6.589 & 5.800 & -0.221 & -0.833 & 0.937 & -0.221 & 1.771 & -27.922 \\
\hline RUN2256 & $\begin{array}{l}\text { NPR20 Str } \\
\text { Metal }\end{array}$ & $A=0.020$ & 7.403 & 8.275 & 8.312 & 8.661 & 0.056 & 0.035 & 0.027 & 0.056 & -0.008 & -25.248 \\
\hline RUN2257 & $\begin{array}{l}\text { NPR20 Str } \\
\text { Metal }\end{array}$ & $A=0.016$ & 5.825 & 6.102 & 6.234 & 6.499 & -0.027 & 0.024 & 0.037 & -0.027 & 0.013 & -18.834 \\
\hline RUN2258 & $\begin{array}{l}\text { NPR20 Str } \\
\text { Metal }\end{array}$ & $A=0.012$ & 4.218 & 4.124 & 4.190 & 4.415 & 0.004 & 0.018 & 0.007 & 0.004 & -0.011 & -12.729 \\
\hline RUN2259 & $\begin{array}{l}\text { NPR20 Str } \\
\text { Metal }\end{array}$ & $A=0.008$ & 2.416 & 1.832 & 1.914 & 1.819 & -0.035 & 0.002 & -0.042 & -0.035 & -0.044 & -5.565 \\
\hline RUN2260 & $\begin{array}{l}\text { NPR20 Str } \\
\text { Metal }\end{array}$ & $A=0.006$ & 1.551 & 0.729 & 0.879 & 0.813 & -0.047 & 0.003 & -0.019 & -0.047 & -0.022 & -2.421 \\
\hline RUN2261 & $\begin{array}{l}\text { NPR20 Str } \\
\text { Metal Stan }\end{array}$ & $A=0.020$ & 7.444 & 9.610 & 10.099 & 10.044 & -0.203 & 0.086 & 0.024 & -0.203 & -0.062 & -29.752 \\
\hline RUN2262 & $\begin{array}{l}\text { NPR20 Str } \\
\text { Metal Stan }\end{array}$ & $A=0.016$ & 5.714 & 7.107 & 7.206 & 7.361 & -0.139 & 0.057 & 0.004 & -0.139 & -0.053 & -21.674 \\
\hline
\end{tabular}




\begin{tabular}{|c|c|c|c|c|c|c|c|c|c|c|c|c|c|c|c|}
\hline $\begin{array}{c}\begin{array}{c}\text { Run } \\
\text { Number }\end{array} \\
\end{array}$ & $\begin{array}{l}\text { Nozzle } \\
\text { Type }\end{array}$ & Mx & My & $\mathrm{Mz}$ & $W p$ & Wi & $\mathrm{Fi}$ & $\mathrm{Fr}$ & $\mathbf{F}_{\text {vector }}$ & $\mathrm{Fr} / \mathrm{Fi}$ & Fz/Fi & Wp/Wi & pitch & yaw & $r$ \\
\hline & & in-lbf & in-lbf & in-lbf & $\mathrm{lbm} / \mathrm{s}$ & $\mathrm{lbm} / \mathrm{s}$ & lbf & lbf & $\mathrm{lbf}$ & & & & & & \\
\hline RUN2081 & $\begin{array}{l}\text { NPR20 } \\
\text { Hole }\end{array}$ & 2.549 & -46.065 & 0.149 & 0.579 & 0.552 & 30.062 & 27.918 & 1.785 & 0.929 & -0.927 & 1.050 & 0.265 & 3.657 & -3.666 \\
\hline RUN2082 & $\begin{array}{l}\text { NPR20 } \\
\text { Hole }\end{array}$ & 2.915 & -43.960 & 0.252 & 0.569 & 0.549 & 29.498 & 27.856 & 1.791 & 0.944 & -0.942 & 1.035 & 0.148 & 3.683 & -3.685 \\
\hline RUN2083 & $\begin{array}{l}\text { NPR20 } \\
\text { Hole }\end{array}$ & 3.394 & -45.195 & 0.290 & 0.569 & 0.548 & 29.523 & 27.882 & 1.762 & 0.944 & -0.943 & 1.038 & 0.206 & 3.618 & -3.623 \\
\hline RUN2084 & $\begin{array}{l}\text { NPR20 } \\
\text { Hole }\end{array}$ & -46.373 & -2.915 & 0.343 & 0.574 & 0.549 & 29.760 & 28.092 & 1.703 & 0.944 & -0.942 & 1.046 & -3.455 & 0.380 & -3.476 \\
\hline RUN2085 & $\begin{array}{l}\text { NPR20 } \\
\text { Hole }\end{array}$ & -45.787 & -3.102 & 0.354 & 0.578 & 0.549 & 29.955 & 28.222 & 1.768 & 0.942 & -0.940 & 1.053 & -3.564 & 0.441 & -3.591 \\
\hline RUN2086 & $\begin{array}{l}\text { NPR20 } \\
\text { Hole }\end{array}$ & -46.691 & -3.420 & 0.416 & 0.578 & 0.549 & 29.959 & 27.979 & 1.784 & 0.934 & -0.932 & 1.051 & -3.629 & 0.454 & -3.657 \\
\hline RUN2256 & $\begin{array}{l}\text { NPR20 } \\
\text { Str } \\
\text { Metal }\end{array}$ & 1.057 & 1.514 & 0.247 & 0.469 & 0.548 & 24.129 & 25.248 & 0.056 & 1.046 & -1.046 & 0.857 & 0.018 & -0.127 & -0.128 \\
\hline RUN2257 & $\begin{array}{l}\text { NPR20 } \\
\text { Str } \\
\text { Metal }\end{array}$ & 1.323 & 1.149 & 0.246 & 0.371 & 0.431 & 18.188 & 18.834 & 0.030 & 1.036 & -1.036 & 0.862 & -0.039 & 0.082 & -0.091 \\
\hline RUN2258 & $\begin{array}{l}\text { NPR20 } \\
\text { Str } \\
\text { Metal }\end{array}$ & 0.894 & 0.974 & 0.102 & 0.267 & 0.312 & 12.091 & 12.730 & 0.012 & 1.053 & -1.053 & 0.857 & 0.049 & -0.020 & -0.053 \\
\hline RUN2259 & $\begin{array}{l}\text { NPR20 } \\
\text { Str } \\
\text { Metal }\end{array}$ & 0.174 & -0.415 & -0.162 & 0.149 & 0.179 & 5.483 & 5.565 & 0.057 & 1.015 & -1.015 & 0.836 & 0.454 & 0.365 & -0.583 \\
\hline RUN2260 & $\begin{array}{l}\text { NPR20 } \\
\text { Str } \\
\text { Metal }\end{array}$ & 0.581 & -0.287 & -0.068 & 0.082 & 0.115 & 2.202 & 2.421 & 0.052 & 1.099 & -1.099 & 0.717 & 0.519 & 1.120 & -1.234 \\
\hline RUN2261 & $\begin{array}{l}\text { NPR20 } \\
\text { Str } \\
\text { Metal } \\
\text { Stan }\end{array}$ & 2.307 & -0.238 & 0.437 & 0.563 & 0.550 & 28.991 & 29.753 & 0.212 & 1.026 & -1.026 & 1.023 & 0.120 & 0.390 & -0.408 \\
\hline RUN2262 & $\begin{array}{l}\text { NPR20 } \\
\text { Str } \\
\text { Metal } \\
\text { Stan }\end{array}$ & 0.884 & 0.672 & 0.245 & 0.426 & 0.422 & 20.779 & 21.674 & 0.149 & 1.043 & -1.043 & 1.008 & 0.139 & 0.368 & -0.393 \\
\hline
\end{tabular}




\begin{tabular}{|c|c|c|c|c|c|c|c|c|c|c|c|c|}
\hline $\begin{array}{l}\text { Run } \\
\text { Number }\end{array}$ & Nozzle Type & Notes & $\begin{array}{l}\text { Right } \\
\text { NPR }\end{array}$ & $\begin{array}{c}\text { Corrected } \\
\text { R1 }\end{array}$ & $\begin{array}{c}\text { Corrected } \\
\text { R2 } \\
\end{array}$ & $\begin{array}{c}\text { Corrected } \\
\text { R3 } \\
\end{array}$ & $\begin{array}{c}\text { Corrected } \\
\text { R4 }\end{array}$ & $\begin{array}{c}\text { Corrected } \\
\text { R5 }\end{array}$ & $\begin{array}{c}\text { Corrected } \\
\text { R6 }\end{array}$ & $F x$ & Fy & $\mathrm{Fz}$ \\
\hline & & & & $\mathrm{lbf}$ & $\mathrm{lbf}$ & $\mathrm{lbf}$ & $\mathrm{lbf}$ & $\mathrm{lbf}$ & $\mathrm{lbf}$ & $\mathrm{lbf}$ & $\mathrm{lbf}$ & $\mathrm{lbf}$ \\
\hline RUN2263 & $\begin{array}{l}\text { NPR20 Str } \\
\text { Metal Stan }\end{array}$ & $A=0.012$ & 3.956 & 4.400 & 4.552 & 4.633 & -0.029 & 0.003 & -0.004 & -0.029 & -0.007 & -13.585 \\
\hline RUN2264 & $\begin{array}{l}\text { NPR20 Str } \\
\text { Metal Stan }\end{array}$ & $A=0.008$ & 2.491 & 2.283 & 2.410 & 2.484 & -0.029 & 0.043 & 0.010 & -0.029 & -0.034 & -7.177 \\
\hline RUN2265 & $\begin{array}{l}\text { NPR20 Str } \\
\text { Metal Stan }\end{array}$ & $A=0.006$ & 1.503 & 0.777 & 0.920 & 0.893 & -0.009 & 0.014 & -0.001 & -0.009 & -0.015 & -2.589 \\
\hline RUN2266 & $\begin{array}{l}\text { NPR20 Metal } \\
\text { Port }\end{array}$ & $A=0.020$ & 7.331 & 10.761 & 18.602 & 2.305 & -2.890 & 0.069 & 0.069 & -2.890 & 0.000 & -31.668 \\
\hline RUN2267 & $\begin{array}{l}\text { NPR20 Metal } \\
\text { Port }\end{array}$ & $A=0.016$ & 5.631 & 7.846 & 13.535 & 1.572 & -2.065 & -0.033 & 0.005 & -2.065 & 0.038 & -22.952 \\
\hline RUN2268 & $\begin{array}{l}\text { NPR20 Metal } \\
\text { Port }\end{array}$ & $A=0.012$ & 3.880 & 4.838 & 8.454 & 0.961 & -1.294 & -0.040 & 0.036 & -1.294 & 0.076 & -14.253 \\
\hline RUN2269 & $\begin{array}{l}\text { NPR20 Metal } \\
\text { Port }\end{array}$ & $A=0.008$ & 2.389 & 2.423 & 4.252 & 0.561 & -0.696 & 0.006 & 0.000 & -0.696 & -0.005 & -7.236 \\
\hline RUN2270 & $\begin{array}{l}\text { NPR20 Metal } \\
\text { Port }\end{array}$ & $A=0.006$ & 1.534 & 0.958 & 1.675 & 0.272 & -0.249 & -0.022 & -0.033 & -0.249 & -0.011 & -2.905 \\
\hline RUN2271 & $\begin{array}{l}\text { NPR20 Hole } \\
3\end{array}$ & $A=0.020$ & 7.420 & 9.997 & 18.551 & 0.109 & -3.171 & 0.007 & 0.145 & -3.171 & 0.138 & -28.657 \\
\hline RUN2272 & $\begin{array}{l}\text { NPR20 Hole } \\
3\end{array}$ & $A=0.016$ & 5.200 & 6.471 & 12.091 & 0.090 & -2.153 & -0.053 & 0.048 & -2.153 & 0.101 & -18.651 \\
\hline RUN2273 & $\begin{array}{l}\text { NPR20 Hole } \\
3\end{array}$ & $A=0.012$ & 4.065 & 4.625 & 8.912 & -0.097 & -1.644 & 0.003 & -0.026 & -1.644 & -0.029 & -13.439 \\
\hline RUN2274 & $\begin{array}{l}\text { NPR20 Hole } \\
3\end{array}$ & $A=0.008$ & 2.168 & 1.836 & 3.467 & 0.086 & -0.538 & -0.026 & -0.009 & -0.538 & 0.016 & -5.389 \\
\hline RUN2275 & $\begin{array}{l}\text { NPR20 Hole } \\
3\end{array}$ & $A=0.006$ & 1.502 & 0.791 & 1.550 & 0.139 & -0.267 & 0.004 & -0.005 & -0.267 & -0.008 & -2.480 \\
\hline
\end{tabular}




\begin{tabular}{|c|c|c|c|c|c|c|c|c|c|c|c|c|c|c|c|}
\hline $\begin{array}{c}\text { Run } \\
\text { Number }\end{array}$ & Nozzle Type & $\mathrm{Mx}$ & My & $\mathrm{Mz}$ & Wp & Wi & $\mathrm{Fi}$ & $\mathrm{Fr}$ & $\mathbf{F}_{\text {vector }}$ & $\mathrm{Fr} / \mathrm{Fi}$ & $\mathrm{Fz} / \mathrm{Fi}$ & Wp/Wi & pitch & yaw & $\mathrm{r}$ \\
\hline & & in-lbf & in-lbf & in-lbf & $\mathrm{lbm} / \mathrm{s}$ & $\mathrm{lbm} / \mathrm{s}$ & $\mathrm{lbf}$ & $\mathrm{lbf}$ & $\mathrm{lbf}$ & & & & & & \\
\hline RUN2263 & $\begin{array}{l}\text { NPR20 Str Metal } \\
\text { Stan }\end{array}$ & 0.960 & 0.349 & -0.002 & 0.310 & 0.292 & 13.808 & 13.585 & 0.030 & 0.984 & -0.984 & 1.059 & 0.030 & 0.123 & -0.126 \\
\hline RUN2264 & $\begin{array}{l}\text { NPR20 Str Metal } \\
\text { Stan }\end{array}$ & 0.821 & 0.318 & 0.212 & 0.175 & 0.184 & 6.527 & 7.177 & 0.044 & 1.100 & -1.100 & 0.949 & 0.270 & 0.229 & -0.354 \\
\hline RUN2265 & $\begin{array}{l}\text { NPR20 Str Metal } \\
\text { Stan }\end{array}$ & 0.647 & -0.115 & 0.053 & 0.100 & 0.111 & 2.573 & 2.590 & 0.018 & 1.006 & -1.006 & 0.896 & 0.336 & 0.195 & -0.389 \\
\hline RUN2266 & $\begin{array}{l}\text { NPR20 Metal } \\
\text { Port }\end{array}$ & -1.535 & -70.615 & 0.556 & 0.655 & 0.542 & 33.641 & 31.799 & 2.890 & 0.945 & -0.941 & 1.209 & 0.000 & 5.214 & -5.214 \\
\hline RUN2267 & $\begin{array}{l}\text { NPR20 Metal } \\
\text { Port }\end{array}$ & -1.462 & -51.835 & -0.113 & 0.512 & 0.416 & 24.912 & 23.045 & 2.066 & 0.925 & -0.921 & 1.229 & -0.094 & 5.141 & -5.142 \\
\hline RUN2268 & $\begin{array}{l}\text { NPR20 Metal } \\
\text { Port }\end{array}$ & -0.654 & -32.469 & -0.013 & 0.339 & 0.287 & 15.064 & 14.312 & 1.296 & 0.950 & -0.946 & 1.183 & -0.307 & 5.188 & -5.197 \\
\hline RUN2269 & $\begin{array}{l}\text { NPR20 Metal } \\
\text { Port }\end{array}$ & -0.083 & -15.992 & 0.024 & 0.208 & 0.177 & 7.609 & 7.269 & 0.696 & 0.955 & -0.951 & 1.178 & 0.041 & 5.494 & -5.494 \\
\hline RUN2270 & $\begin{array}{l}\text { NPR20 Metal } \\
\text { Port }\end{array}$ & 0.080 & -6.081 & -0.222 & 0.106 & 0.113 & 2.805 & 2.916 & 0.249 & 1.040 & -1.036 & 0.935 & 0.219 & 4.903 & -4.908 \\
\hline RUN2271 & NPR20 Hole 3 & -3.337 & -79.909 & 0.605 & 0.631 & 0.548 & 32.508 & 28.832 & 3.174 & 0.887 & -0.882 & 1.152 & -0.276 & 6.314 & -6.320 \\
\hline RUN2272 & NPR20 Hole 3 & -1.906 & -52.000 & -0.019 & 0.453 & 0.384 & 21.689 & 18.776 & 2.156 & 0.866 & -0.860 & 1.179 & -0.310 & 6.586 & -6.593 \\
\hline RUN2273 & NPR20 Hole 3 & -1.087 & -39.039 & -0.091 & 0.347 & 0.300 & 15.558 & 13.540 & 1.645 & 0.870 & -0.864 & 1.155 & 0.122 & 6.976 & -6.977 \\
\hline RUN2274 & NPR20 Hole 3 & -0.295 & -14.651 & -0.141 & ERROR & 0.160 & ERROR & 5.416 & 0.538 & ERROR & ERROR & ERROR & -0.172 & 5.700 & -5.702 \\
\hline RUN2275 & NPR20 Hole 3 & 0.270 & -6.111 & -0.003 & 0.093 & 0.111 & 2.407 & 2.494 & 0.267 & 1.036 & -1.030 & 0.840 & 0.190 & 6.147 & -6.150 \\
\hline
\end{tabular}




\begin{tabular}{|c|c|c|c|c|c|c|c|c|c|c|c|c|}
\hline $\begin{array}{l}\text { Run } \\
\text { Number }\end{array}$ & Nozzle Type & Notes & $\begin{array}{c}\text { Right } \\
\text { NPR }\end{array}$ & $\begin{array}{c}\text { Corrected } \\
\text { R1 }\end{array}$ & $\begin{array}{c}\text { Corrected } \\
\text { R2 } \\
\end{array}$ & $\begin{array}{c}\text { Corrected } \\
\text { R3 }\end{array}$ & $\begin{array}{c}\text { Corrected } \\
\text { R4 }\end{array}$ & $\begin{array}{c}\text { Corrected } \\
\text { R5 }\end{array}$ & $\begin{array}{c}\text { Corrected } \\
\text { R6 }\end{array}$ & Fx & Fy & $\mathbf{F z}$ \\
\hline & & & & Ibf & Ibf & $\mathrm{lbf}$ & $\mathrm{lbf}$ & $\mathrm{lbf}$ & $\mathrm{lbf}$ & lbf & $\mathrm{lbf}$ & Ibf \\
\hline RUN2281 & $\begin{array}{l}\text { NPR20 Hole } \\
5\end{array}$ & $A=0.020$ & 7.409 & 10.202 & 21.729 & -3.487 & -4.374 & -0.105 & 0.156 & -4.374 & 0.261 & -28.444 \\
\hline RUN2282 & $\begin{array}{l}\text { NPR20 Hole } \\
5\end{array}$ & $A=0.016$ & 5.774 & 7.504 & 16.170 & -2.575 & -3.214 & -0.059 & 0.163 & -3.214 & 0.222 & -21.098 \\
\hline RUN2283 & $\begin{array}{l}\text { NPR20 Hole } \\
5\end{array}$ & $A=0.012$ & 3.857 & 4.560 & 9.728 & -1.673 & -1.975 & -0.078 & 0.053 & -1.975 & 0.131 & -12.615 \\
\hline RUN2284 & $\begin{array}{l}\text { NPR20 Hole } \\
5\end{array}$ & $A=0.008$ & 2.338 & 2.307 & 4.693 & -0.890 & -0.939 & -0.059 & 0.024 & -0.939 & 0.083 & -6.111 \\
\hline RUN2285 & $\begin{array}{l}\text { NPR20 Hole } \\
5\end{array}$ & $A=0.006$ & 1.506 & 0.973 & 1.933 & -0.310 & -0.403 & -0.025 & 0.002 & -0.403 & 0.027 & -2.595 \\
\hline \multicolumn{13}{|l|}{ NPR 50} \\
\hline RUN2031 & NPR50 STR4 & & 7.571 & 7.547 & 8.150 & 7.823 & -0.055 & 0.073 & -0.005 & -0.055 & -0.078 & -23.520 \\
\hline RUN2032 & NPR50 STR4 & & 7.552 & 7.449 & 8.044 & 8.121 & -0.144 & 0.103 & -0.017 & -0.144 & -0.119 & -23.614 \\
\hline RUN2033 & NPR50 STR4 & $\begin{array}{l}\text { rotated } 90 \\
\text { degrees } \\
\mathrm{CW}\end{array}$ & 7.594 & 8.267 & 8.010 & 6.534 & -0.205 & -0.045 & 0.123 & -0.205 & 0.168 & -22.812 \\
\hline RUN2034 & NPR50 STR4 & $\begin{array}{l}\text { rotated } 90 \\
\text { degrees } \\
\mathrm{CW}\end{array}$ & 7.640 & 8.177 & 8.213 & 6.302 & -0.274 & 0.000 & 0.159 & -0.274 & 0.160 & -22.692 \\
\hline RUN2035 & NPR50 STR4 & $\begin{array}{l}\text { rotated } 180 \\
\text { degrees } \\
\mathrm{CW}\end{array}$ & 7.617 & 8.597 & 6.848 & 8.158 & 0.184 & -0.076 & 0.183 & 0.184 & 0.259 & -23.604 \\
\hline RUN2036 & NPR50 STR4 & $\begin{array}{l}\text { rotated } 180 \\
\text { degrees } \\
\mathrm{CW}\end{array}$ & 7.599 & 8.636 & 6.880 & 8.245 & 0.020 & -0.088 & 0.160 & 0.020 & 0.248 & -23.761 \\
\hline RUN2037 & NPR50 STR4 & $\begin{array}{l}\text { rotated } 270 \\
\text { degrees } \\
\mathrm{CW}\end{array}$ & 7.582 & 7.346 & 7.010 & 8.125 & 0.311 & 0.091 & -0.024 & 0.311 & -0.115 & -22.481 \\
\hline
\end{tabular}




\begin{tabular}{|c|c|c|c|c|c|c|c|c|c|c|c|c|c|c|c|}
\hline $\begin{array}{c}\text { Run } \\
\text { Number }\end{array}$ & Nozzle Type & Mx & My & Mz & Wp & Wi & $\mathbf{F i}$ & $\mathrm{Fr}$ & $\mathbf{F}_{\text {vector }}$ & Fr/Fi & $\mathrm{Fz} / \mathrm{Fi}$ & Wp/Wi & pitch & yaw & $r$ \\
\hline & & in-lbf & in-lbf & in-lbf & $\mathrm{lbm} / \mathrm{s}$ & $\mathrm{lbm} / \mathrm{s}$ & $\mathrm{lbf}$ & $\mathrm{lbf}$ & lbf & & & & & & \\
\hline RUN2281 & NPR20 Hole 5 & -5.405 & -109.263 & 0.202 & 0.641 & 0.546 & 33.053 & 28.779 & 4.381 & 0.871 & -0.861 & 1.173 & -0.526 & 8.741 & -8.757 \\
\hline RUN2282 & NPR20 Hole 5 & -3.533 & -81.222 & 0.417 & 0.498 & 0.426 & 24.452 & 21.343 & 3.222 & 0.873 & -0.863 & 1.171 & -0.603 & 8.663 & -8.683 \\
\hline RUN2283 & NPR20 Hole 5 & -2.665 & -49.398 & -0.101 & 0.323 & 0.284 & 14.384 & 12.769 & 1.979 & 0.888 & -0.877 & 1.135 & -0.594 & 8.897 & -8.916 \\
\hline RUN2284 & NPR20 Hole 5 & -2.025 & -24.191 & -0.140 & 0.190 & 0.172 & 6.897 & 6.183 & 0.943 & 0.897 & -0.886 & 1.103 & -0.776 & 8.739 & -8.772 \\
\hline RUN2285 & NPR20 Hole 5 & -0.805 & -9.721 & -0.090 & 0.105 & 0.111 & 2.724 & 2.627 & 0.404 & 0.964 & -0.953 & 0.945 & -0.588 & 8.832 & -8.851 \\
\hline \multicolumn{16}{|l|}{ NPR 50} \\
\hline RUN2031 & NPR50 STR4 & 2.196 & -1.416 & 0.271 & 0.461 & 0.478 & 24.041 & 23.520 & 0.095 & 0.978 & -0.978 & 0.964 & 0.189 & 0.135 & -0.232 \\
\hline RUN2032 & NPR50 STR4 & 3.168 & 0.336 & 0.344 & 0.487 & 0.477 & 25.388 & 23.615 & 0.187 & 0.930 & -0.930 & 1.021 & 0.289 & 0.348 & -0.453 \\
\hline RUN2033 & NPR50 STR4 & -4.975 & -6.395 & 0.311 & 0.489 & 0.479 & 25.569 & 22.814 & 0.265 & 0.892 & -0.892 & 1.022 & -0.421 & 0.514 & -0.665 \\
\hline RUN2034 & NPR50 STR4 & -4.595 & -8.282 & 0.637 & 0.456 & 0.489 & 23.792 & 22.694 & 0.317 & 0.954 & -0.954 & 0.933 & -0.403 & 0.691 & -0.800 \\
\hline RUN2035 & NPR50 STR4 & -5.470 & 5.678 & 0.430 & 0.475 & 0.487 & 24.784 & 23.606 & 0.318 & 0.952 & -0.952 & 0.976 & -0.630 & -0.445 & -0.771 \\
\hline RUN2036 & NPR50 STR4 & -5.370 & 5.914 & 0.287 & 0.463 & 0.486 & 24.119 & 23.763 & 0.248 & 0.985 & -0.985 & 0.952 & -0.597 & -0.048 & -0.599 \\
\hline RUN2037 & NPR50 STR4 & 1.104 & 4.831 & 0.265 & 0.478 & 0.484 & 24.934 & 22.483 & 0.331 & 0.902 & -0.902 & 0.987 & 0.293 & -0.792 & -0.844 \\
\hline
\end{tabular}




\begin{tabular}{|c|c|c|c|c|c|c|c|c|c|c|c|c|}
\hline $\begin{array}{l}\text { Run } \\
\text { Number }\end{array}$ & Nozzle Type & Notes & $\begin{array}{l}\text { Right } \\
\text { NPR }\end{array}$ & $\begin{array}{c}\text { Corrected } \\
\text { R1 } \\
\end{array}$ & $\begin{array}{c}\text { Corrected } \\
\text { R2 } \\
\end{array}$ & $\begin{array}{c}\text { Corrected } \\
\text { R3 }\end{array}$ & $\begin{array}{c}\text { Corrected } \\
\text { R4 } \\
\end{array}$ & $\begin{array}{c}\text { Corrected } \\
\text { R5 }\end{array}$ & $\begin{array}{c}\text { Corrected } \\
\text { R6 }\end{array}$ & Fx & Fy & $\mathbf{F z}$ \\
\hline & & & & $\mathrm{Ibf}$ & $\mathrm{lbf}$ & $\mathrm{lbf}$ & $\mathrm{Ibf}$ & $\mathrm{lbf}$ & $\mathrm{lbf}$ & $\mathrm{Ibf}$ & $\mathrm{lbf}$ & $\mathrm{Ibf}$ \\
\hline RUN2038 & NPR50 STR4 & $\begin{array}{l}\text { rotated } 270 \\
\text { degrees } \\
\mathrm{CW} \\
\end{array}$ & 7.587 & 7.336 & 7.117 & 8.071 & 0.225 & 0.116 & -0.001 & 0.225 & -0.117 & -22.523 \\
\hline RUN2121 & NPR50 STR4 & & 7.733 & 7.235 & 8.576 & 8.138 & -0.177 & 0.196 & -0.030 & -0.177 & -0.226 & -23.949 \\
\hline RUN2122 & NPR50 STR4 & & 7.678 & 7.168 & 8.374 & 8.217 & -0.040 & 0.226 & -0.034 & -0.040 & -0.259 & -23.760 \\
\hline RUN2123 & NPR50 STR4 & & 7.541 & 7.000 & 8.243 & 8.110 & -0.075 & 0.199 & 0.029 & -0.075 & -0.170 & -23.353 \\
\hline RUN2191 & $\begin{array}{l}\text { NPR50 Hole } \\
2\end{array}$ & & 7.543 & 8.030 & 24.308 & -7.403 & -5.187 & 0.141 & 0.015 & -5.187 & -0.126 & -24.935 \\
\hline RUN2192 & $\begin{array}{l}\text { NPR50 Hole } \\
2\end{array}$ & & 7.556 & 8.287 & 24.264 & -7.523 & -5.336 & 0.128 & 0.105 & -5.336 & -0.023 & -25.028 \\
\hline RUN2193 & $\begin{array}{l}\text { NPR50 Hole } \\
2\end{array}$ & & 7.518 & 8.359 & 23.874 & -7.450 & -5.275 & 0.069 & 0.085 & -5.275 & 0.016 & -24.783 \\
\hline RUN2194 & $\begin{array}{l}\text { NPR50 Hole } \\
3\end{array}$ & & 7.521 & 8.986 & 17.117 & -1.531 & -3.047 & -0.103 & 0.228 & -3.047 & 0.331 & -24.573 \\
\hline RUN2195 & $\begin{array}{l}\text { NPR50 Hole } \\
3\end{array}$ & & 7.484 & 8.932 & 17.074 & -1.640 & -3.197 & -0.054 & 0.193 & -3.197 & 0.247 & -24.366 \\
\hline RUN2196 & $\begin{array}{l}\text { NPR50 Hole } \\
3\end{array}$ & & 7.594 & 9.124 & 17.165 & -1.549 & -3.236 & -0.090 & 0.225 & -3.236 & 0.314 & -24.740 \\
\hline RUN2197 & $\begin{array}{l}\text { NPR50 Hole } \\
3\end{array}$ & & 7.569 & 9.079 & 17.203 & -1.584 & -3.140 & -0.084 & 0.202 & -3.140 & 0.286 & -24.698 \\
\hline RUN2118 & $\begin{array}{l}\text { NPR50 } \\
\text { Straight Hole }\end{array}$ & & 7.614 & 8.892 & 12.997 & 1.556 & -1.986 & -0.097 & 0.232 & -1.986 & 0.330 & -23.445 \\
\hline RUN2119 & $\begin{array}{l}\text { NPR50 } \\
\text { Straight Hole }\end{array}$ & & 7.663 & 9.046 & 12.959 & 1.629 & -1.986 & -0.078 & 0.232 & -1.986 & 0.310 & -23.634 \\
\hline
\end{tabular}




\begin{tabular}{|c|c|c|c|c|c|c|c|c|c|c|c|c|c|c|c|}
\hline $\begin{array}{c}\text { Run } \\
\text { Number }\end{array}$ & Nozzle Type & $\mathrm{Mx}$ & My & Mz & Wp & Wi & $\mathrm{Fi}$ & $\mathrm{Fr}$ & $\mathbf{F}_{\text {vector }}$ & $\mathrm{Fr} / \mathrm{Fi}$ & Fz/Fi & Wp/Wi & pitch & yaw & $r$ \\
\hline & & in-lbf & in-lbf & in-lbf & $\mathrm{lbm} / \mathrm{s}$ & $\mathrm{lbm} / \mathrm{s}$ & lbf & lbf & lbf & & & & & & \\
\hline RUN2038 & NPR50 STR4 & 1.290 & 4.132 & 0.458 & 0.466 & 0.484 & 24.307 & 22.525 & 0.253 & 0.927 & -0.927 & 0.961 & 0.297 & -0.572 & -0.644 \\
\hline RUN2121 & NPR50 STR4 & 5.609 & -1.901 & 0.663 & 0.487 & 0.487 & 25.733 & 23.951 & 0.287 & 0.931 & -0.931 & 1.002 & 0.540 & 0.422 & -0.685 \\
\hline RUN2122 & NPR50 STR4 & 5.637 & -0.678 & 0.769 & 0.464 & 0.483 & 24.499 & 23.761 & 0.263 & 0.970 & -0.970 & 0.962 & 0.626 & 0.096 & -0.633 \\
\hline RUN2123 & NPR50 STR4 & 5.880 & -0.577 & 0.913 & 0.502 & 0.474 & 26.400 & 23.354 & 0.186 & 0.885 & -0.885 & 1.059 & 0.417 & 0.184 & -0.456 \\
\hline RUN2191 & NPR50 Hole 2 & 2.112 & -137.402 & 0.621 & 0.608 & 0.477 & 31.667 & 25.469 & 5.189 & 0.804 & -0.787 & 1.275 & 0.290 & 11.751 & -11.755 \\
\hline RUN2192 & NPR50 Hole 2 & 0.415 & -137.734 & 0.930 & 0.584 & 0.478 & 30.433 & 25.590 & 5.336 & 0.841 & -0.822 & 1.223 & 0.053 & 12.035 & -12.035 \\
\hline RUN2193 & NPR50 Hole 2 & -0.733 & -135.724 & 0.614 & 0.580 & 0.475 & 30.195 & 25.338 & 5.275 & 0.839 & -0.821 & 1.220 & -0.036 & 12.015 & -12.015 \\
\hline RUN2194 & NPR50 Hole 3 & -5.965 & -80.802 & 0.497 & 0.537 & 0.475 & 27.981 & 24.764 & 3.065 & 0.885 & -0.878 & 1.131 & -0.772 & 7.069 & -7.110 \\
\hline RUN2195 & NPR50 Hole 3 & -6.077 & -81.087 & 0.558 & 0.543 & 0.473 & 28.266 & 24.576 & 3.206 & 0.869 & -0.862 & 1.149 & -0.582 & 7.474 & -7.496 \\
\hline RUN2196 & NPR50 Hole 3 & -6.579 & -81.085 & 0.540 & 0.548 & 0.480 & 28.611 & 24.952 & 3.251 & 0.872 & -0.865 & 1.143 & -0.728 & 7.451 & -7.486 \\
\hline RUN2197 & NPR50 Hole 3 & -6.348 & -81.404 & 0.471 & 0.531 & 0.478 & 27.668 & 24.898 & 3.153 & 0.900 & -0.893 & 1.109 & -0.663 & 7.245 & -7.275 \\
\hline RUN2118 & NPR50 Straight Hole & -8.077 & -49.571 & 0.539 & 0.516 & 0.480 & 27.075 & 23.531 & 2.013 & 0.869 & -0.866 & 1.073 & -0.805 & 4.841 & -4.907 \\
\hline RUN2119 & NPR50 Straight Hole & -8.759 & -49.092 & 0.614 & 0.496 & 0.483 & 26.105 & 23.720 & 2.010 & 0.909 & -0.905 & 1.027 & -0.751 & 4.802 & -4.860 \\
\hline
\end{tabular}




\begin{tabular}{|c|c|c|c|c|c|c|c|c|c|c|c|c|}
\hline $\begin{array}{l}\text { Run } \\
\text { Number }\end{array}$ & Nozzle Type & Notes & $\begin{array}{l}\text { Right } \\
\text { NPR }\end{array}$ & $\begin{array}{c}\text { Corrected } \\
\text { R1 }\end{array}$ & $\begin{array}{c}\text { Corrected } \\
\text { R2 } \\
\end{array}$ & $\begin{array}{c}\text { Corrected } \\
\text { R3 }\end{array}$ & $\begin{array}{c}\text { Corrected } \\
\text { R4 }\end{array}$ & $\begin{array}{c}\text { Corrected } \\
\text { R5 }\end{array}$ & $\begin{array}{c}\text { Corrected } \\
\text { R6 }\end{array}$ & $F x$ & Fy & $\mathbf{F z}$ \\
\hline & & & & $\mathrm{lbf}$ & $\mathrm{lbf}$ & $\mathrm{lbf}$ & $\mathrm{lbf}$ & $\mathrm{lbf}$ & $\mathrm{lbf}$ & $\mathrm{lbf}$ & $\mathrm{lbf}$ & $\mathrm{lbf}$ \\
\hline RUN2120 & $\begin{array}{l}\text { NPR50 } \\
\text { Straight Hole }\end{array}$ & & 7.570 & 8.876 & 12.744 & 1.634 & -1.861 & -0.080 & 0.221 & -1.861 & 0.301 & -23.255 \\
\hline RUN2241 & NPR50 Str & $A=0.020$ & 7.511 & 6.815 & 8.416 & 7.895 & -0.119 & 0.175 & -0.027 & -0.119 & -0.201 & -23.126 \\
\hline RUN2242 & NPR50 Str & $A=0.016$ & 5.941 & 5.119 & 6.297 & 6.139 & -0.039 & 0.144 & -0.042 & -0.039 & -0.186 & -17.555 \\
\hline RUN2243 & NPR50 Str & $A=0.012$ & 3.894 & 2.803 & 3.904 & 3.499 & -0.163 & 0.102 & -0.081 & -0.163 & -0.182 & -10.205 \\
\hline RUN2244 & NPR50 Str & $A=0.008$ & 2.497 & 1.409 & 2.087 & 1.913 & -0.098 & 0.067 & -0.053 & -0.098 & -0.120 & -5.409 \\
\hline RUN2245 & NPR50 Str & $A=0.006$ & 1.496 & 0.446 & 0.841 & 0.871 & -0.028 & 0.043 & -0.034 & -0.028 & -0.077 & -2.158 \\
\hline RUN2246 & $\begin{array}{l}\text { NPR50 Hole } \\
3\end{array}$ & $A=0.020$ & 7.479 & 8.849 & 17.338 & -1.784 & -3.274 & -0.044 & 0.141 & -3.274 & 0.185 & -24.402 \\
\hline RUN2247 & $\begin{array}{l}\text { NPR50 Hole } \\
3\end{array}$ & $A=0.016$ & 5.835 & 6.512 & 12.732 & -1.212 & -2.428 & -0.076 & 0.087 & -2.428 & 0.163 & -18.032 \\
\hline RUN2248 & $\begin{array}{l}\text { NPR50 Hole } \\
3\end{array}$ & $A=0.012$ & 4.226 & 4.401 & 8.466 & -0.769 & -1.608 & -0.086 & 0.060 & -1.608 & 0.146 & -12.097 \\
\hline RUN2249 & $\begin{array}{l}\text { NPR50 Hole } \\
3\end{array}$ & $A=0.008$ & 2.494 & 2.214 & 3.995 & -0.466 & -0.798 & -0.057 & 0.022 & -0.798 & 0.079 & -5.743 \\
\hline RUN2250 & $\begin{array}{l}\text { NPR50 Hole } \\
3\end{array}$ & $A=0.006$ & 1.501 & 0.869 & 1.541 & -0.106 & -0.308 & -0.014 & 0.022 & -0.308 & 0.036 & -2.305 \\
\hline
\end{tabular}




\begin{tabular}{|c|c|c|c|c|c|c|c|c|c|c|c|c|c|c|c|}
\hline Run Numbe & Nozzle Type & Mx & My & $\mathrm{Mz}$ & Wp & Wi & $\mathrm{Fi}$ & $\mathrm{Fr}$ & $F_{\text {vector }}$ & $\mathrm{Fr} / \mathrm{Fi}$ & $\mathrm{Fz} / \mathrm{Fi}$ & Wp/Wi & pitch & yaw & $r$ \\
\hline & & in-lbf & in-lbf & in-lbf & $\mathrm{lbm} / \mathrm{s}$ & $\mathrm{lbm} / \mathrm{s}$ & Ibf & $\mathrm{lbf}$ & $\mathrm{lbf}$ & & & & & & \\
\hline RUN2120 & $\begin{array}{l}\text { NPR50 } \\
\text { Straight Hole }\end{array}$ & -8.436 & -48.138 & 0.565 & 0.520 & 0.477 & 27.342 & 23.331 & 1.885 & 0.853 & -0.851 & 1.091 & -0.741 & 4.576 & -4.635 \\
\hline RUN2241 & NPR50 Str & 6.704 & -2.258 & 0.592 & 0.476 & 0.484 & 24.514 & 23.128 & 0.234 & 0.943 & -0.943 & 0.984 & 0.499 & 0.296 & -0.580 \\
\hline RUN2242 & NPR50 Str & 5.496 & -0.686 & 0.405 & 0.359 & 0.383 & 17.654 & 17.556 & 0.190 & 0.994 & -0.994 & 0.939 & 0.607 & 0.127 & -0.621 \\
\hline RUN2243 & NPR50 Str & 4.493 & -1.756 & 0.085 & 0.243 & 0.251 & 10.736 & 10.208 & 0.245 & 0.951 & -0.951 & 0.970 & 1.023 & 0.916 & -1.373 \\
\hline RUN2244 & NPR50 Str & 2.952 & -0.753 & 0.054 & 0.149 & 0.161 & 5.546 & 5.411 & 0.155 & 0.976 & -0.975 & 0.924 & 1.266 & 1.040 & -1.638 \\
\hline RUN2245 & NPR50 Str & 2.048 & 0.129 & 0.035 & 0.084 & 0.096 & 2.140 & 2.159 & 0.082 & 1.009 & -1.008 & 0.865 & 2.033 & 0.743 & -2.164 \\
\hline RUN2246 & $\begin{array}{l}\text { NPR50 Hole } \\
\text { (small) }\end{array}$ & -5.358 & -82.858 & 0.387 & 0.554 & 0.482 & 28.487 & 24.622 & 3.279 & 0.864 & -0.857 & 1.150 & -0.434 & 7.642 & -7.654 \\
\hline RUN2247 & NPR50 Hole 3 & -3.758 & -60.419 & 0.045 & 0.416 & 0.376 & 20.360 & 18.196 & 2.434 & 0.894 & -0.886 & 1.107 & -0.517 & 7.669 & -7.686 \\
\hline RUN2248 & NPR50 Hole 3 & -2.765 & -40.016 & -0.105 & 0.330 & 0.272 & 14.901 & 12.205 & 1.615 & 0.819 & -0.812 & 1.211 & -0.692 & 7.571 & -7.602 \\
\hline RUN2249 & NPR50 Hole 3 & -2.249 & -19.331 & -0.138 & 0.174 & 0.161 & 6.486 & 5.799 & 0.802 & 0.894 & -0.885 & 1.083 & -0.786 & 7.913 & -7.951 \\
\hline RUN2250 & NPR50 Hole 3 & -0.759 & -7.134 & 0.034 & 0.096 & 0.097 & 2.458 & 2.326 & 0.310 & 0.946 & -0.937 & 0.987 & -0.888 & 7.616 & -7.667 \\
\hline
\end{tabular}

